\title{
Hydrogeologic Framework, Analysis of Ground-Water Flow, and Relations to Regional Flow in the Fall Zone Near Richmond, Virginia
}

By E. Randolph McFarland

\section{U.S. GEOLOGICAL SURVEY}

Water-Resources Investigations Report 97-4021

Prepared in cooperation with the

VIRGINIA DEPARTMENT OF ENVIRONMENTAL QUALITY 


\title{
U.S. DEPARTMENT OF THE INTERIOR BRUCE BABBITT, Secretary
}

\author{
U.S. GEOLOGICAL SURVEY \\ Gordon P. Eaton, Director
}

For additional information write to:

District Chief

U.S. Geological Survey

3600 West Broad Street, Room 606

Richmond, VA 23230-4916
Copies of this report can be purchased from:

U.S. Geological Survey

Information Services

Box 25286

Denver, CO 80225-0046 


\section{CONTENTS}

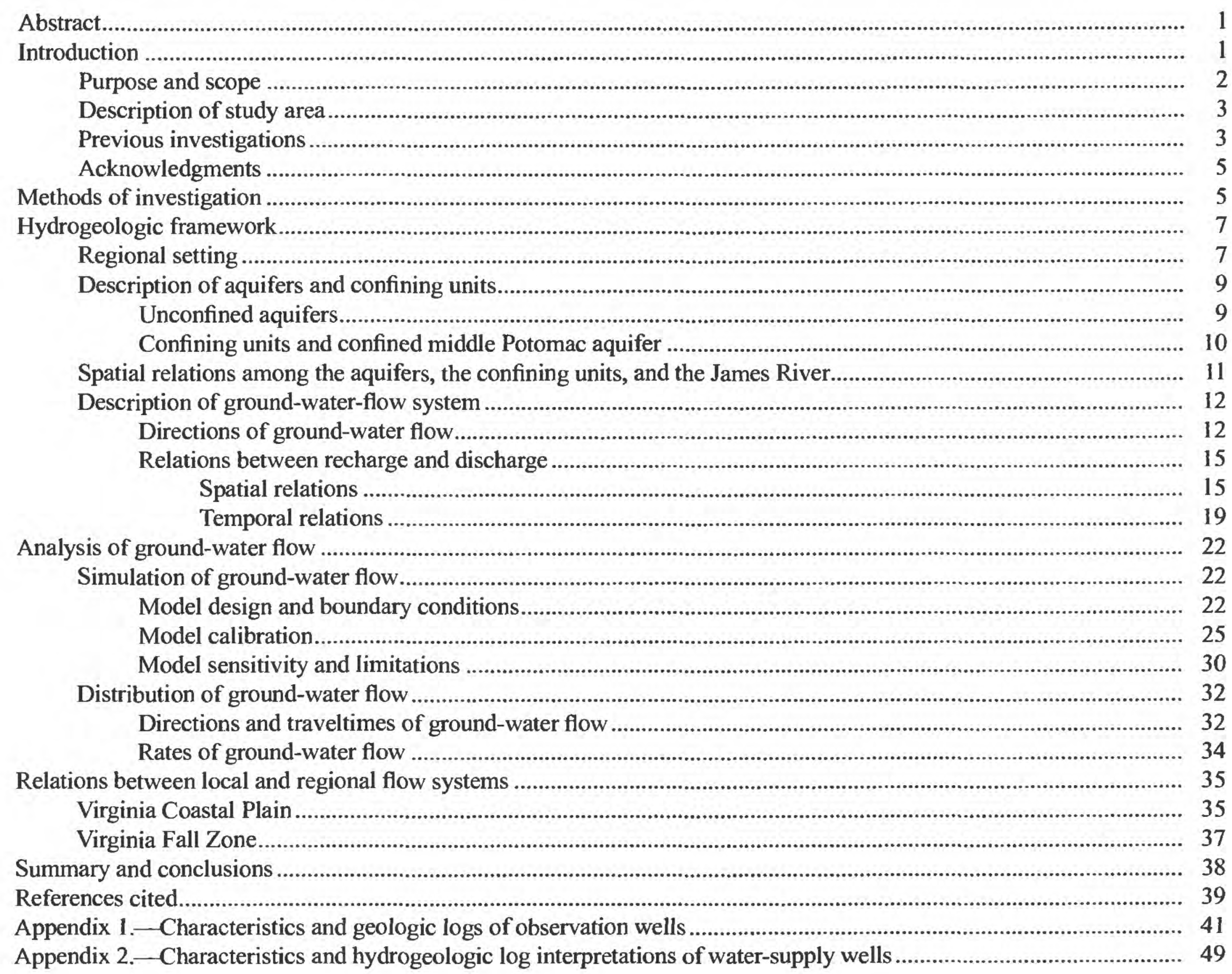

\section{PLATE}

1. Hydrogeologic sections, directions of ground-water flow, and chlorofluorocarbon-model recharge ages of ground water In pocket

\section{FIGURES}

\section{1, 2. Maps showing:}

1. Physiographic provinces, James River Basin, and location of study area ..

2. Locations of observation wells, water-supply wells, and seepage sites

3. Generalized hydrogeologic section and direction of ground-water flow in the Coastal Plain Province of Virginia 
4, 5. Maps showing:

4. Configuration of the water table

5. Potentiometric surface of the middle Potomac aquifer

6-8. Graphs showing measured water levels in observation wells in the:

6. Uplands

7. Lowland

8. Floodplain and tidal fluctuations of the James River

9. Map showing design features of the ground-water-flow model .................................................................. 23

10. Diagram showing conceptualized ground-water-flow system

11, 12. Maps showing:

11. Simulated configuration of the water table in the upper layer that represents the unconfined Columbia and Yorktown-Eastover aquifers.

12. Simulated potentiometric surface of the lower layer that represents the confined middle Potomac aquifer

13. Graph showing sensitivity of simulated heads to changes in values of hydraulic properties input to the ground-water-flow model.

\section{TABLES}

1. Aquifer materials and estimated horizontal hydraulic conductivities at observation wells

2. Model calibration input values assigned to cells in the upper layer that represent different parts of the unconfined Columbia and Yorktown-Eastover aquifers.

3. Streambed seepage rate and vertical hydraulic conductivity in the James River 30

4. Simulated rates of ground-water-flow components 


\title{
Hydrogeologic Framework, Analysis of Ground-Water Flow, and Relations to Regional Flow in the Fall Zone Near Richmond, Virginia
}

\author{
By E. Randolph McFarland
}

\section{Abstract}

Incomplete knowledge of the hydrologic processes that control ground-water flow along the western margin of the Coastal Plain Physiographic Province in Virginia, termed the "Fall Zone", has hindered efficient management of the aquifers. Hydrogeologic conditions and groundwater flow were investigated within a 350 -squaremile study area along part of the Fall Zone near Richmond, Va., during 1995-96. Water in the study area is present under unconfined conditions in the Columbia aquifer, which underlies a lowland next to the James and the Appomattox Rivers, and in the Yorktown-Eastover aquifer, which underlies adjoining uplands. Water is present under confined conditions in the underlying middle Potomac aquifer. One or more confining units separate the unconfined aquifers from the confined aquifer, except in parts of the lowland where the James River and the Columbia aquifer are incised into the confined aquifer and confining units. The aquifers and confining units dip eastward and are bounded by bedrock from below and to the west.

Finite-difference numerical simulation of ground-water flow under steady-state conditions indicates that most of the ground water within the study area discharges at the surface, and that relatively little recharges Coastal Plain aquifers outside of the study area. The total rate of flow was assumed to be 10 inches per year (in/yr) as recharge at the water table. The simulation indicates that water is discharged within the study area at a rate of $8.9 \mathrm{in} / \mathrm{yr}$ from the unconfined aquifers to the James and Appomattox Rivers, adjoining wetlands, and tributaries. Water leaks downward to recharge the confined aquifer at a rate of $1.1 \mathrm{in} / \mathrm{yr}$, compared to downward leakage rates of as much as $3.8 \mathrm{in} / \mathrm{yr}$ for the entire Coastal Plain aquifer system in Virginia estimated by earlier studies. Particle-tracking and chlorofluorocarbon, or CFC, age-date analyses indicate that water takes approximately 10 to 50 years to flow from the water table to the base of the unconfined aquifers and into the confined aquifer. From the confined aquifer, water flows back upward at a rate of $0.5 \mathrm{in} / \mathrm{yr}$ to discharge at the surface, and is withdrawn from wells within the study area at a rate of $0.1 \mathrm{in} / \mathrm{yr}$. The remaining ground water within the study area leaves the confined aquifer through the subsurface at a rate of $0.5 \mathrm{in} / \mathrm{yr}$ to provide recharge to regional aquifers in downgradient areas to the northeast and east. Amounts of ground water that contribute to local discharge and regional recharge in other parts of the Fall Zone possibly differ from those in the study area because of different hydrogeologic conditions and withdrawals.

\section{INTRODUCTION}

Aquifers in the Coastal Plain Physiographic Province (Coastal Plain) in Virginia (fig. 1) are a major source of water, accounting for approximately 45 percent of ground-water withdrawals reported to the State (McFarland and Focazio, 1993). As a result, groundwater levels have declined by as much as $200 \mathrm{ft}$, primarily near large withdrawal centers in the 


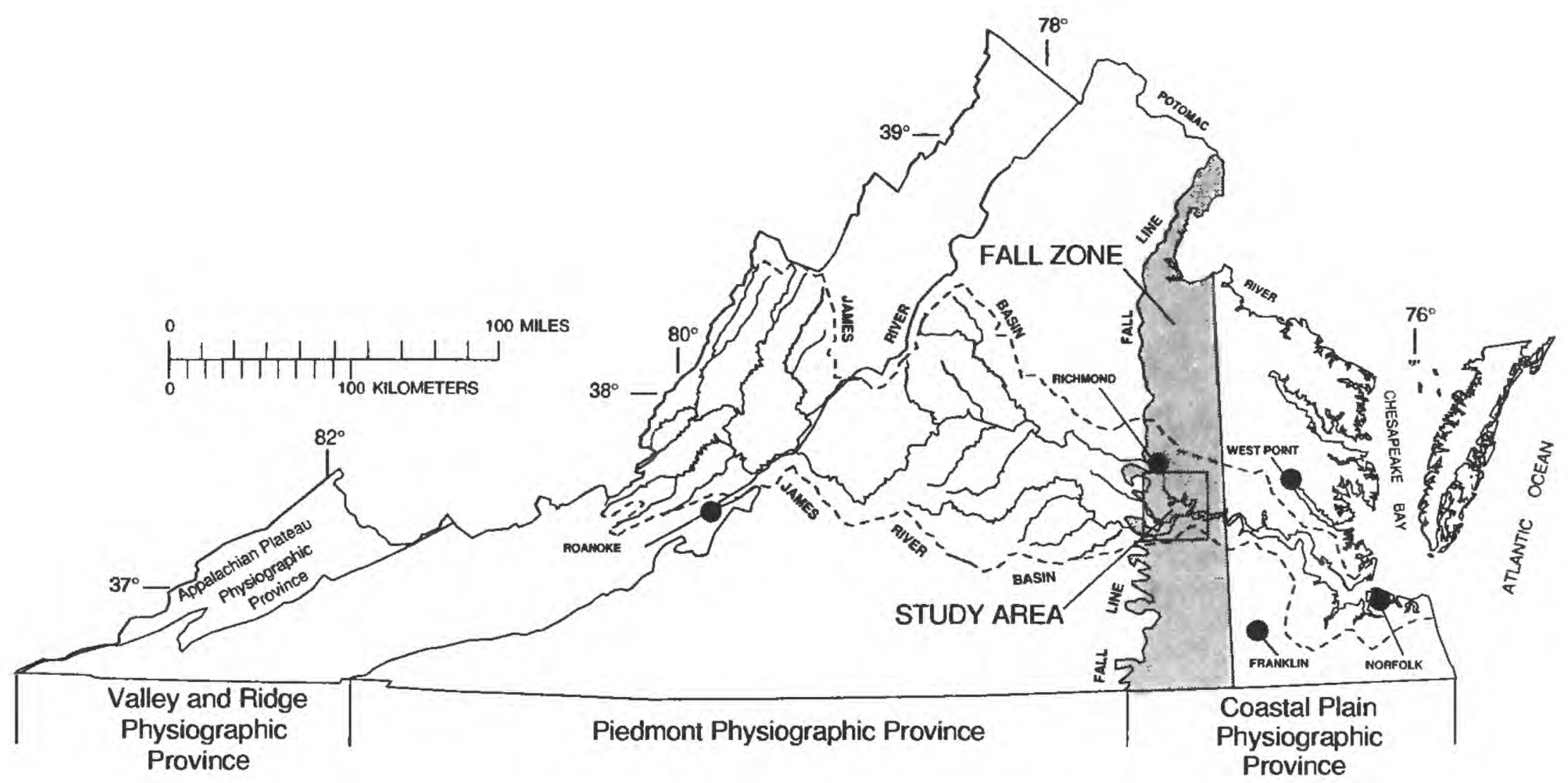

Figure 1. Physiographic provinces, James River Basin, and location of study area in the Fall Zone near Richmond, Virginia.

southeastern part of the State. Further declines could result from increasing withdrawals and could limit continued use of the resource. In addition, the geographic distribution of withdrawals is broadening to include the western margin of the Coastal Plain, termed the "Fall Zone" (fig. 1).

The U.S. Geological Survey (USGS), in cooperation with the Virginia Department of Environmental Quality (DEQ), has analyzed changes in ground-water levels and flow caused by withdrawal from aquifers in the Coastal Plain of Virginia. A digital ground-waterflow model was constructed to study regional-scale patterns of ground-water flow (Harsh and Laczniak, 1990). The model simulates widespread and long-term trends in water-level decline caused by large withdrawals, primarily from deep and thick aquifers. In order to protect the future viability of water supplies, DEQ bases ground-water management decisions for the Coastal Plain aquifers partly on simulations of declines caused by continued and proposed withdrawals. The effectiveness of this approach, however, is limited in part by incomplete knowledge of the hydrologic processes that control ground-water flow along the Fall Zone. Because construction of the model focused on thick, deep aquifers that underlie the central part of the Coastal Plain, simplifying assumptions were incorporated that only approximate the hydrologic processes in the Fall Zone.
In 1995, the USGS began a study in cooperation with DEQ to develop a better understanding of the factors that control ground-water flow within the Fall Zone in Virginia. The study is designed to identify and describe hydrogeologic conditions and processes in the Fall Zone, to determine controls on regional ground-water flow in the Coastal Plain that are imposed by Fall-Zone processes, and to the extent possible - to represent the Fall Zone appropriately in the regional ground-water-flow model. Because the surficial geology and geomorphology of the Fall Zone is complex and diverse, the Fall Zone was delineated into three distinct study areas. Intensive field-based investigation is planned within each study area to identify and describe local-scale hydrogeologic conditions and processes.

\section{Purpose and Scope}

This report presents the results of the investigation of hydrogeologic conditions and ground-waterflow processes in part of the Fall Zone near Richmond, Va., during 1995-96. Lithologic compositions and hydraulic characteristics of aquifers and confining units are presented. The spatial configurations and geological relations of the aquifers and confining units are described. Ground-water-flow directions, sources, 
and sinks are delineated, and temporal changes in recharge and discharge are described.

Different components of ground-water flow are analyzed. Ground-water flow through the study area is simulated by use of a local-scale numerical model. Simulated flow directions and traveltimes, and estimated ground-water ages, are examined. Comparisons are made among simulated recharge at the water table, discharge to surface water, withdrawal, and recharge to the regional flow system.

Relations of local-scale flow processes to the regional-scale flow system are examined. Flow-system conditions within the study area are compared to documented flow-system conditions in other parts of the Virginia Coastal Plain, and to potential conditions in other parts of the Fall Zone.

\section{Description of Study Area}

The study area is located along the James River south of the city of Richmond, Va. (fig. 1). The climate is humid temperate, and annual precipitation is approximately 43 in. (National Weather Service, 1996).

The James River Basin stretches more than 400 mi across the central part of Virginia, from its headwaters near Roanoke to its mouth at Norfolk, and it drains an area of 10,200 $\mathrm{mi}^{2}$ (Seaber and others, 1987). The basin spans several distinct geologic provinces. In the study area, the James River flows eastward from the Piedmont Physiographic Province (Piedmont) through the western margin of the Coastal Plain, termed the "Fall Zone."

The Piedmont is characterized generally by rolling terrain underlain by igneous and metamorphic rocks of late Proterozoic and early Paleozoic age, and residual soils that range in thickness from 0 to $100 \mathrm{ft}$. Fault-bounded structural basins within the Piedmont contain sedimentary and igneous rocks of Mesozoic age. Within the study area, the Piedmont is underlain by the Petersburg granite, a felsic intrusive igneous rock of Mississippian age (Mixon and others, 1989).

The Coastal Plain has well-drained soils. The northwestern part of the Coastal Plain has rolling terrain and deeply incised stream valleys, and the eastern and southern parts have gently rolling-to-level terrain and broad stream valleys and extensive wetlands. The Coastal Plain contains eastward dipping strata of unconsolidated to partly consolidated sediments of
Cretaceous, Tertiary, and Quaternary age that unconformably overlie Piedmont rock.

The hydrogeology of the two provinces is diverse. Ground water in the Piedmont is present in fractures in bedrock and in pores in weathered residuum developed on the bedrock. Ground water in the Coastal Plain is present in pores in the sediments; thick sequences of porous and permeable strata form regional aquifers, and impermeable strata form confining units between the aquifers.

The boundary between the Piedmont and Coastal Plain is referred to as the Fall Line (fig. 1). Numerous falls and rapids are present along streams at the Fall Line, where their gradients increase as they flow from resistant bedrock onto more easily eroded sediments. The configuration of the Fall Line is intricate. Streams have eroded through Coastal Plain sediments to expose bedrock in their valley floors.

Interstream divides are capped by uneroded sediments that overlie the bedrock. The Fall Zone consists of a belt several miles in width that encompasses the complex margin between the Piedmont and Coastal Plain.

The study area lies along the Fall Zone (fig. 1) and encompasses approximately $350 \mathrm{mi}^{2}$ (fig. 2). The James River flows from Richmond southeastward through the central part of the study area, and it is joined at Hopewell by the Appomattox River from the southwest.

The study area is delineated by the Fall Line to the west and the James River Basin boundary to the northeast and southeast (fig. 2). The Fall Line is incised by tributary streams that have eroded through Coastal Plain sediments to the underlying Petersburg granite. Topography is dominated by the valleys of the James and Appomattox Rivers. A lowland consisting of terraces, floodplains, and wetlands encompasses the rivers, and is flanked by broad uplands in the west, northeast, and southeast. The uplands and lowland are bounded by relict erosional scarps associated with the rivers, but which are obscured in places by the present-day tributary drainage pattern. Land-surface elevation ranges from approximately $180 \mathrm{ft}$ in the uplands to near sea level at the James River.

\section{Previous Investigations}

As a result of many investigations conducted during the past several decades, a large amount of information exists about both the Coastal Plain in general and the Coastal Plain in Virginia. Only a very 


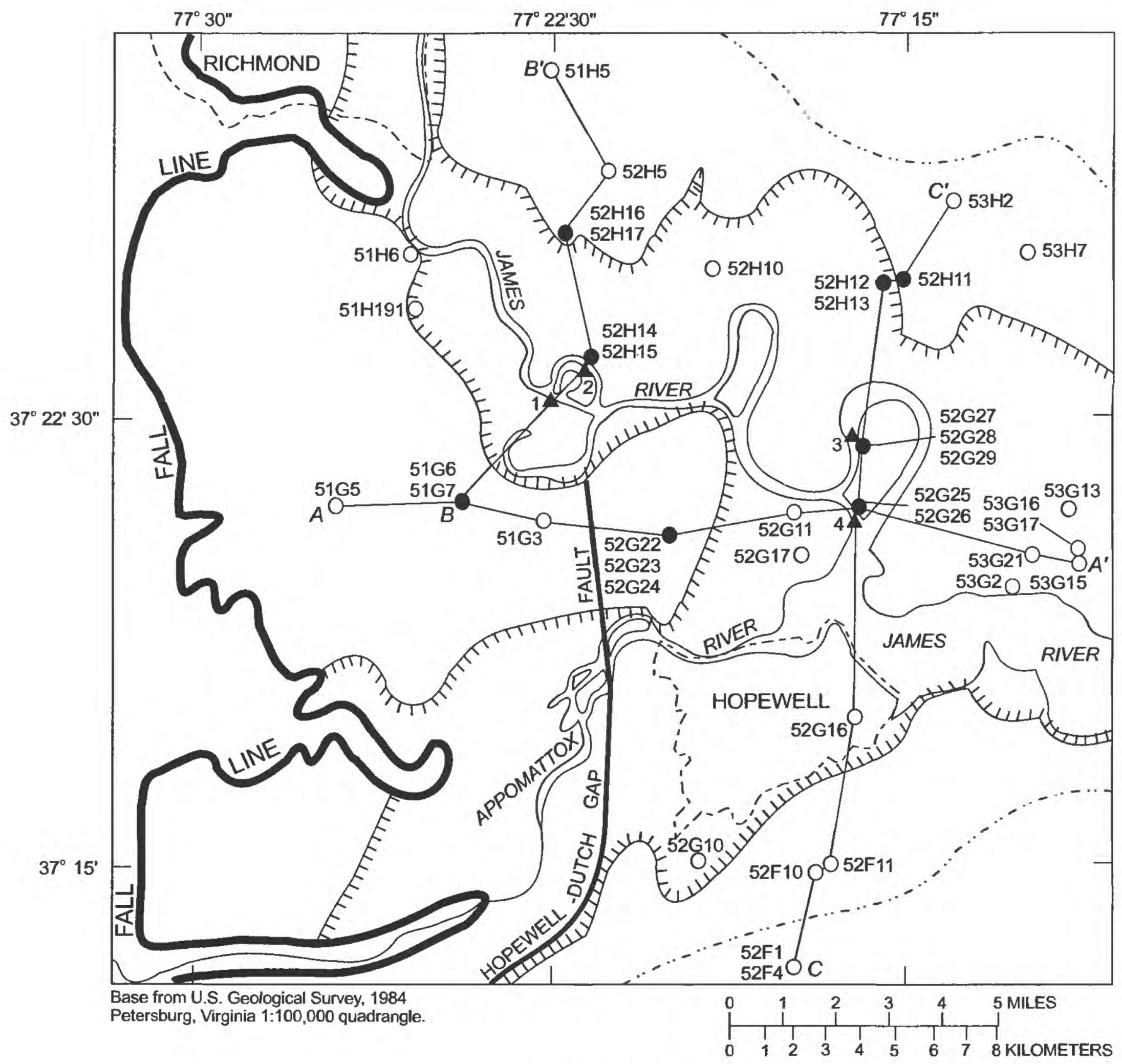

EXPLANATION

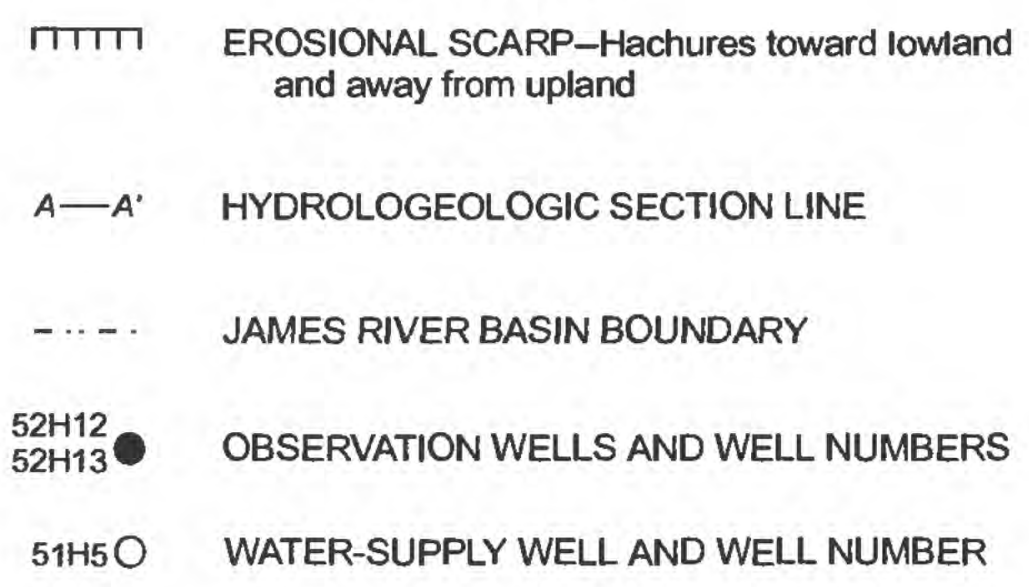

3A STREAMBED SEEPAGE SITE

Figure 2. Locations of observation wells, water-supply wells, and seepage sites in the Fall Zone near Richmond, Virginia. 
brief overview of the most significant and relevant work is presented here.

One of the earliest comprehensive efforts to document physiographic and geological conditions in the Coastal Plain in Virginia was by Clark and Miller (1912). Shortly thereafter, Sanford (1913) completed a comprehensive report on the ground-water resources in the Virginia Coastal Plain. Among subsequent ground-water investigations in Virginia, Cederstrom produced several reports including one of the most significant (Cederstrom, 1945), which remains as a major milestone in the hydrogeology of the Coastal Plain.

Recent investigations in the Coastal Plain in Virginia have been built largely on the results of earlier work. Although many minor revisions have been made, the fundamental aspects of the preceding knowledge have been retained. As a typical example, a comprehensive synthesis of geological studies was incorporated into a revised and highly detailed geologic map of the Virginia Coastal Plain by Mixon and others (1989).

The most comprehensive analysis of the hydrogeology of the Coastal Plain in Virginia to date (1997) was produced by the Regional Aquifer System Analysis (RASA) Program of the USGS. The hydrogeologic framework of the entire Coastal Plain in Virginia was defined by Meng and Harsh (1988), who incorporated the work of many previous studies as well as a large volume of newly collected data. Subsequently, a digital ground-water-flow model was constructed, based on the RASA framework, to study regional-scale patterns of ground-water flow (Harsh and Laczniak, 1990). The hydrogeologic framework and groundwater-flow model have subsequently been modified on the basis of results of more detailed studies in southeastern Virginia (Hamilton and Larson, 1988) and in the York-James Peninsula (Laczniak and Meng, 1988). The current (1996) form of the RASA framework and model provides an interpretive baseline from which many subsequent ground-water investigations have been, and are being, based (including the study presented in this report), for both scientific and resourcemanagement purposes.

Several additional geological investigations were useful for this study to characterize the hydrogeologic framework of the study area. Among these, Ward and Blackwelder (1980) and Ward (1985) provide descriptions of surface exposures of Tertiary-age geologic formations located within the study area and discuss their regional spatial distributions and depositional histories. Johnson and Ramsey (1987) describe Quaternary-age formations within the study area and relate their spatial distributions to the geomorphic evolution of terraces and erosional scarps that characterize the landscape. Dischinger (1987) established numerous stratigraphic and structural relations through the subsurface within the study area, including the alignment of the Hopewell-Dutch Gap fault, a major regional-scale structural element.

\section{Acknowledgments}

The author wishes to thank Terry Wagner, Mary Ann Massie, and especially T. Scott Bruce, of the Virginia Department of Environmental Quality, for program and planning support, and for numerous instances of operational assistance. Permission for access to drilling sites and frequent logistical support were generously provided by Barry Brady, Oscar Reed, Jr., and Luther B. Vick, Jr., of the U.S. Fish and Wildlife Service, Presquile National Wildlife Refuge; Michael Brennan of the National Park Service, Richmond Battlefields National Park; and Nick Froelich and Mark Denny of the Virginia Department of Transportation. C. Richard Berquist of the Virginia Division of Mineral Resources, and Haywood Wigglesworth of Henrico County Public Utilities, provided watersupply-well data. William G. Reay of Virginia Polytechnical Institute assisted in planning and interpreting seepage measurements and provided field equipment. Within the USGS, the drilling operation and the geological framework assistance were provided by David Powars, Stephen Schindler, Gene Cobbs, Sr., and Gene Cobbs, Jr., slug-test assistance was provided by George E. Harlow, Jr., and CFC-sample collection and analysis were facilitated by Eurybiades Busenberg, $\mathrm{L}$. Neil Plummer, and David L. Nelms.

\section{METHODS OF INVESTIGATION}

A network of observation wells was established in the study area (fig. 2) to characterize the groundwater-flow system. Hydrogeologic data were collected at 17 observation wells, which were installed from July through November 1995 at 8 locations. In addition, existing data on 23 water-supply wells located within the study area were used from records on file in 
the Richmond, Va., office of the USGS to supplement the observation-well data.

The observation well network primarily consists of three well transects (fig. 2) from which hydrogeologic sections were constructed (pl. 1). The transects traverse both the uplands and the lowland, and collectively bracket a segment of the James River. Observation wells form the core of the transects and are augmented by 14 of the 23 water-supply wells.

Observation wells were constructed by using a combination of hollow-stem-auger and mud-rotary drilling. Two to three observation wells were constructed at different depths to constitute a multilevel observation-well cluster at each location (pl. 1). The clustered wells are open to different aquifers and (or) different depths within the same aquifer. Samples of aquifer materials were examined and described during drilling from which a geologic log was constructed for the deepest well at each observation-well cluster. Finished well depths range from $9.13 \mathrm{ft}$ to $89.33 \mathrm{ft}$ below land surface. The wells are cased with 2- to 3 -inch inside-diameter polyvinyl chloride (PVC), which is slotted along the bottom 5 to $10 \mathrm{ft}$. The slotted intervals were sand packed except at locations where aquifer materials collapsed onto the slotted casing upon drill-rod removal. Casing intervals passing through confining units were grouted with bentonite. Gamma logs were recorded for the completed wells.

Water levels were measured in the observation wells from August 1995 through July 1996. Instantaneous water levels were measured approximately monthly by use of a hand-held steel-measuring tape at all the wells during most of the period. In addition, continuous water-level measurements were collected from most of the observation wells by use of analogto-digital recorders that were installed during intermittent periods. Continuous measurements collected hourly were used to compute daily mean values.

Well-construction and water-level data were computer processed at the Richmond, Va., office of the USGS. All data are stored in the National Water Information System computer data base. In addition, wellconstruction and log data are on file at the Richmond, Va., office.

Aquifer horizontal hydraulic conductivities were estimated by using single-well "slug" tests on most of the observation wells. A sealed and weighted stainless steel or PVC pipe, or slug, was lowered rapidly into each well to create a nearly instantaneous water-level rise. Water levels were then electronically recorded at microsecond intervals, while water flowed from the well into the surrounding aquifer, and the water level returned to its former position. This "slugin" test was followed by a second "slug-out" test in which the slug was rapidly removed from the well to create a nearly instantaneous water-level decline. Water levels were again recorded, while water flowed into the well from the surrounding aquifer, and the water level returned to its former position. The rate of water-level recovery is proportional to the horizontal hydraulic conductivity of the aquifer. Horizontal hydraulic conductivity of the aquifer at each observation well was estimated by slug test analysis by use of the Bouwer and Rice (1976) and van der Kamp (1976) methods.

The age of water in different parts of the aquifers was estimated by analyzing concentrations of chlorofluorocarbon compounds, or CFC's, in water samples collected from most of the observation wells. Water samples were collected from the observation wells during April 1996. Water standing in the well casing was removed by pumping approximately three well casing volumes while ground-water $\mathrm{pH}$, temperature, specific conductance, and dissolved oxygen concentration were monitored. Samples were collected after the monitored readings stabilized. Ground-water samples were analyzed at the USGS laboratory in Reston, Va., for CFC-11 (trichlorofluoromethane), CFC-12 (dichlorodifluoromethane), and CFC-113 (trichlorotrifluoroethane). In addition, the groundwater samples were analyzed for dissolved nitrogen and argon gases to aid in determining recharge temperatures, which must be known to interpret recharge ages.

Rates of ground-water discharge as seepage into the James River were estimated at four sites along the river in the study area (fig. 2). The methods used were based on those of Lee (1977). In order to intercept and measure the volume of seepage, one or two seepage meters were placed into the streambed at each seepage-site location for periods of 3 to 25 hours, after which the volume of water collected by the seepage meters was measured.

River water and discharging ground water are mixed both in the seepage meter and within the streambed sediment before being collected by a seepage meter. Accordingly, the rate of ground-water discharge was calculated based on a mass-balance mixing equation, which uses the measured specific conductances 
of the collected seepage-meter water, river water, and ground water at nearby observation wells.

In addition to the seepage rate, the vertical hydraulic conductivity of the streambed was estimated at two of the seepage sites. A minipiezometer was driven into the streambed, and with a bulb manometer was used to measure vertical hydraulic gradients across the streambed. Vertical hydraulic conductivities were calculated by using the measured vertical gradients and seepage rates. Vertical gradients could not be measured at the other two seepage sites because the fine-grained riverbed sediments clogged the minipiezometer openings.

\section{HYDROGEOLOGIC FRAMEWORK}

The regional ground-water-flow system in which the study area is located consists of a thick sequence of stratified sediments that forms a hydrogeologic framework of aquifers and confining units. The local flow system within the study area consists of the unconfined Columbia and Yorktown-Eastover aquifers and the underlying confined middle Potomac aquifer. Confining units separate the unconfined aquifers from the confined aquifers, except where the James River and Columbia aquifer are incised into the confined aquifer and confining units. Unconfined ground water flows from uplands toward the James and Appomattox Rivers and discharges into the rivers, and leaks downward into the confined aquifer. Confined ground water flows back upward into the unconfined aquifers, is withdrawn from wells, and flows through the confined aquifer and out of the study area to provide recharge to regional aquifers. Water levels fluctuate in response to recharge and tidal interactions with the James River.

\section{Regional Setting}

At the Fall Line, bedrock from the Piedmont dips beneath a seaward thickening wedge of largely unconsolidated sediment that underlies the Coastal Plain (fig. 3). Coastal Plain sediments were deposited during a series of transgressions and regressions by the Atlantic Ocean that resulted from changes in sea level. The sediment wedge stretches from Cape Cod, Mass., southward to the Gulf of Mexico, and extends offshore to the continental shelf. The thickness of the sediment wedge in Virginia ranges from $0 \mathrm{ft}$ at the Fall Line to more than $6,000 \mathrm{ft}$ along the Atlantic Coast (Onuschak, 1972).

The sediments consist of eastward dipping but largely undeformed stratified deposits. A thick sequence of nonmarine strata primarily of Cretaceous age is overlain by a much thinner sequence of marine strata of Tertiary age (Meng and Harsh, 1988). This sequence is in turn overlain by a veneer of nearly flatlying terrace and floodplain deposits primarily of Quaternary age.

The Quaternary-age sediments constitute a steplike succession of terraces and intervening scarps that parallel the coast and major streams, and which dominate the topography of the Coastal Plain (Johnson and Ramsey, 1987). The terraces decrease in elevation toward the coast and major streams, and decrease in age with lower elevation. Terrace sediments were deposited at successively lower elevations as a result of sea-level decline. The scarps were initially cut into the older formations as shorelines, but were then subjected to subaerial erosion and are now obscured in places.

The Coastal Plain sediment sequence forms a hydrogeologic framework of aquifers and confining units (Meng and Harsh, 1988). Permeable formations from which significant amounts of water can be drawn are known as aquifers, and less permeable formations that restrict ground-water flow are known as confining units (fig. 3). Because of their great thicknesses and large areal extents, Coastal Plain aquifers provide a widely used ground-water supply (Heath, 1984).

Geologic formations are delineated by the depositional history of the sediments, whereas aquifers are delineated by their water-bearing properties. As a result, aquifers are conventionally named to designate their principal corresponding geologic formations but, because of variations in sediment composition and hydrologic characteristics, geologic formation and aquifer names do not precisely coincide in all areas. Relations among geologic formations and aquifers in the Coastal Plain in Virginia were established by the RASA study of the USGS (Meng and Harsh, 1988), which presents a complete description but is not reiterated in this report.

Most of the water supplied from Coastal Plain aquifers in Virginia is withdrawn from the upper Potomac-Brightseat, middle Potomac, and lower Potomac aquifers (McFarland and Focazio, 1993), which consist mostly of Cretaceous-age nonmarine deposits. These aquifers are confined throughout most 


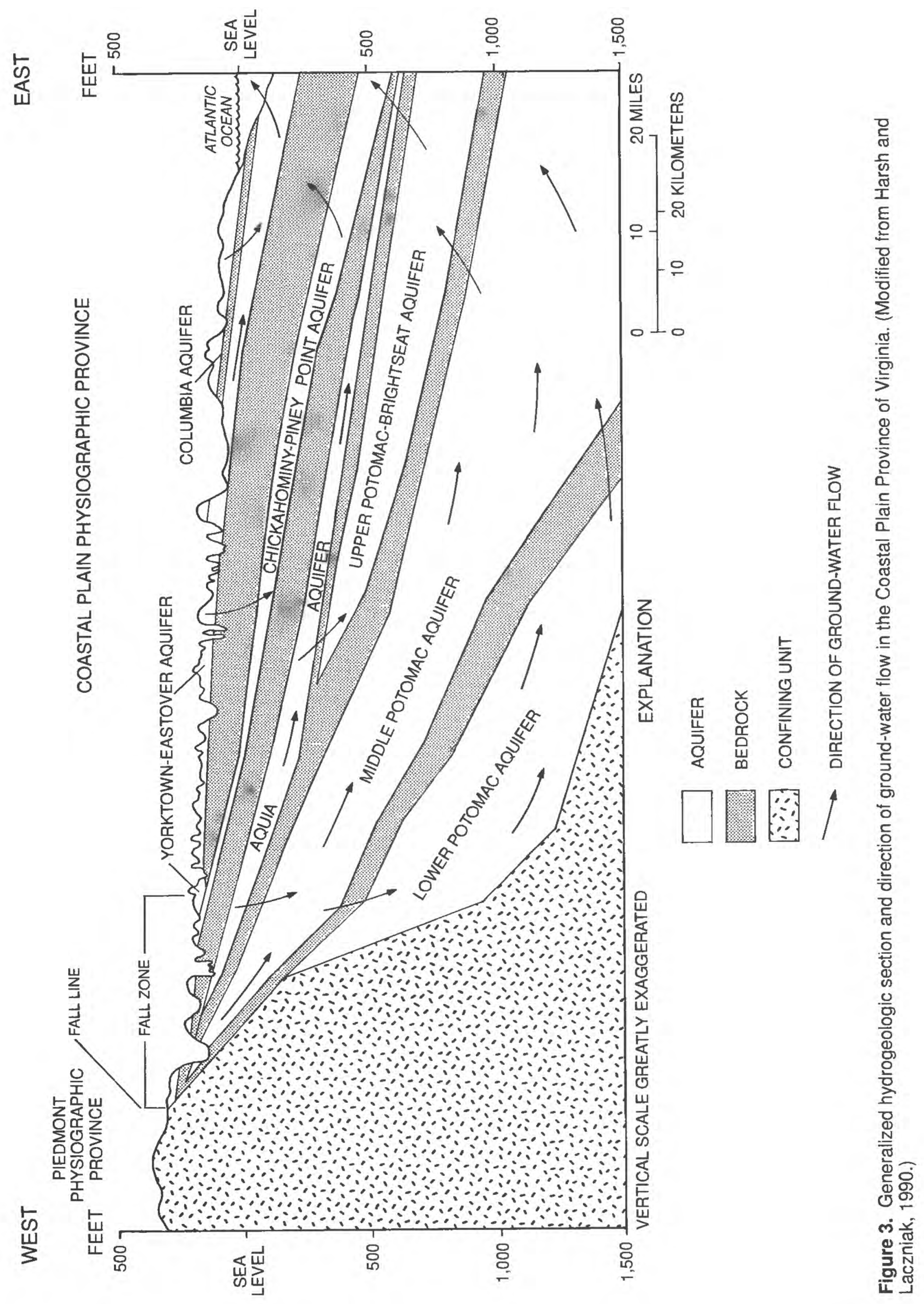

8 Hydrogeologic Framework, Analysis of Ground-Water Flow, and Relations to Regional Flow in the Fall Zone, Richmond, Va. 
of the Coastal Plain, except for small parts of the middle Potomac aquifer that are unconfined in narrow outcrop areas adjacent to major rivers in the Fall Zone

(fig. 3). Less water is supplied from the overlying Yorktown-Eastover, Chickahominy-Piney Point, and Aquia aquifers, which consist mostly of Tertiary-age marine deposits. These aquifers also are confined throughout most of the Coastal Plain, except for the Yorktown-Eastover aquifer, which is unconfined where it crops out across much of the western part of the Coastal Plain (fig. 3). The Columbia aquifer provides water principally for domestic and small municipal supplies, and it largely consists of Quaternary-age terrace and floodplain deposits. The Columbia aquifer is entirely unconfined and is areally extensive only in the eastern part of the Coastal Plain (fig. 3). In the western part, the Columbia aquifer is restricted to floodplains and local terraces adjacent to major rivers, which are separated by uplands underlain by Yorktown-Eastover sediments.

Much of the unconfined ground water flows relatively short distances and discharges to nearby streams, but a small amount flows downward to recharge the deeper confined aquifers. Recharge to the confined aquifers primarily is along the Fall Zone and beneath surface-drainage divides between major river valleys (Harsh and Laczniak, 1990). Flow through the confined aquifers primarily is lateral in the down-dip direction to the east and toward large withdrawal centers and major discharge areas near large rivers and coastal water (fig. 3). Because of stratification of the sediments, horizontal hydraulic conductivity generally is greater than vertical hydraulic conductivity. The confined aquifers discharge by upward flow across intervening confining units to discharge areas.

\section{Description of Aquifers and Confining Units}

The vertical positions, areal extents, and hydraulic properties of aquifers and confining units within the study area were determined. Well-log data from observation wells (appendix 1) and water-supply wells (appendix 2) within the study area were used to infer the presence of aquifers and confining units and correlate them among the wells. In addition, published geologic maps, stratigraphic data, and hydrogeologic analyses were used to supplement the well logs (see section on "Previous Investigations"). Chief among these, the hydrogeologic framework of the Coastal
Plain in Virginia established by the RASA study of the USGS (Meng and Harsh, 1988), including modifications based on subsequent studies (Hamilton and Larson, 1988; Laczniak and Meng, 1988), provided an interpretive baseline from which well logs and supplemental information were analyzed. Horizontal hydraulic conductivities of the aquifers were estimated from slug-test data collected from observation wells (table 1).

\section{Unconfined Aquifers}

At the Fall Line near the western edge of the study area, the Petersburg granite near the land surface dips eastward beneath Coastal Plain sediments. A lowland along the James and Appomattox Rivers extends across the central part of the study area (fig. 2). The lowland is underlain by the Windsor, Charles City, Chuckatuck, Shirley, and Tabb Formations and alluvium (Johnson and Ramsey, 1987), and it occupies parts of the lower Coastal Plain terraces defined as the Lackey, Grove, and Grafton Plains and the Huntington and Todds Flats.

Data from observation wells and water-supply wells, and examination of numerous surface exposures, indicate that the lowland is underlain primarily by very poorly sorted sand, gravel, cobbles, and boulders with noncohesive silt and clay. Ground water is present in these sediments under unconfined conditions. Hydrologically, the sediments represent the western part of the unconfined Columbia aquifer. Estimates of horizontal hydraulic conductivity of the Columbia aquifer range from 5.6 to $76 \mathrm{ft} / \mathrm{d}$ (table 1), with a median of $47 \mathrm{ft} / \mathrm{d}$, and generally are of the largest magnitude in the study area.

The lowland is flanked by uplands in the western, northeastern, and southeastern parts of the study area that are underlain by the Bon Air gravel and Yorktown and Bacons Castle Formations (Johnson and Ramsey, 1987). The uplands occupy parts of the upper and middle Coastal Plain terraces defined as the Midlothian Uplands, Richmond Plain, and Norge Uplands. The upland in the western part of the study area also may be underlain in part by the Eastover Formation (S.J. Schindler, U.S. Geological Survey, oral commun., 1995).

Data from observation wells and water-supply wells, and examination of numerous surface exposures, indicate that the uplands are underlain in some areas by well-sorted quartz sand, and in other areas by poorly sorted quartz sand and gravel having dense, 
Table 1. Aquifer materials and estimated horizontal hydraulic conductivities (by slug-test analyses) at observation wells in the Fall Zone near Richmond, Virginia

\begin{tabular}{|c|c|c|}
\hline Well number & Aquifer material & $\begin{array}{l}\text { Estimated horizontal } \\
\text { hydraulic conductivity } \\
\text { (feet per day) }\end{array}$ \\
\hline \multicolumn{3}{|c|}{ Columbla aquifer } \\
\hline $\begin{array}{l}52 \mathrm{G} 25 \\
52 \mathrm{G} 27 \\
52 \mathrm{G} 28 \\
52 \mathrm{H} 12 \\
52 \mathrm{H} 13\end{array}$ & $\begin{array}{c}\text { sand } \\
\text { sand } \\
\text { sand and gravel } \\
\text { sand } \\
\text { sand and gravel }\end{array}$ & $\begin{array}{l}9.9 \\
5.6 \\
76 . \\
54 . \\
47 .\end{array}$ \\
\hline \multicolumn{3}{|c|}{ Yorktown-Eastover aquifer } \\
\hline $\begin{array}{l}51 \mathrm{G} 6 \\
51 \mathrm{G} 7 \\
52 \mathrm{G} 22 \\
52 \mathrm{H} 11 \\
52 \mathrm{H} 16\end{array}$ & $\begin{array}{l}\text { sand and gravel } \\
\text { sand } \\
\text { clayey sand } \\
\text { sand } \\
\text { sand and gravel }\end{array}$ & $\begin{array}{l}1.3 \\
.53 \\
1.3 \\
.0084 \\
.39\end{array}$ \\
\hline \multicolumn{3}{|c|}{ Middle Potomac aquifer } \\
\hline $\begin{array}{l}52 \mathrm{G} 23 \\
52 \mathrm{G} 24 \\
52 \mathrm{G} 26 \\
52 \mathrm{G} 29 \\
52 \mathrm{H} 15 \\
52 \mathrm{H} 17\end{array}$ & $\begin{array}{l}\text { clayey sand and gravel } \\
\text { clayey sand and gravel } \\
\text { sand } \\
\text { silty sand } \\
\text { sand } \\
\text { sand }\end{array}$ & $\begin{array}{c}.27 \\
.22 \\
6.1 \\
.26 \\
.76 \\
1.1\end{array}$ \\
\hline
\end{tabular}

cohesive silt and clay. Ground water is present in these sediments under unconfined conditions. Hydrologically, the sediments represent the western unconfined part of the Yorktown-Eastover aquifer. Estimates of horizontal hydraulic conductivity of the YorktownEastover aquifer range from 0.0084 to $1.3 \mathrm{ft} / \mathrm{d}$ (table 1), with a median of $0.53 \mathrm{ft} / \mathrm{d}$.

\section{Confining Units and Confined Middle Potomac Aquifer}

Stratigraphic correlation among well-log data (appendixes 1 and 2) along section lines between the wells (fig. 2) indicates that, within the study area, the unconfined Yorktown-Eastover and Columbia aquifers are underlain primarily by the confined middle Potomac aquifer and several intervening confining units (pl. 1). One or more confining units separate the unconfined aquifers from the middle Potomac aquifer throughout most of the study area. The confining units consist of fine sand, silt, and clay marine deposits of the Saint Marys, Nanjemoy, and Aquia Formations of Tertiary age, based on well-log data (appendix 1) and other lithologic descriptions (Ward and Blackwelder, 1980; Ward, 1985). These confining units were corre- lated with water-supply-well logs from which the positions of other confining units also were extrapolated (appendix 2).

The middle Potomac aquifer primarily consists of fluvial sediments of the Potomac Formation of Cretaceous age (Meng and Harsh, 1988). Lithologic descriptions from observation wells and water-supply wells, and examination of surface exposures, indicate that the middle Potomac aquifer consists of mediumto-coarse sand and gravel having interbedded discontinuous lenses of silt and clay. Ground water is present in these sediments primarily under confined conditions throughout most of the study area. Some areas along the James and Appomattox Rivers possibly are under semiconfined conditions, where river channels and the unconfined Columbia aquifer are incised into the middle Potomac aquifer, and where the overlying confining unit has been removed by erosion or dredging (pl. 1). In addition, small areas possibly are under unconfined conditions along narrow outcrops next to the James River. Estimates of horizontal hydraulic conductivity of the middle Potomac aquifer range from 0.22 to $6.1 \mathrm{ft} / \mathrm{d}$ (table 1 ), with a median of $0.52 \mathrm{ft} / \mathrm{d}$. 
A confining unit also underlies much of the middle Potomac aquifer separating it from the Piedmont bedrock (pl. 1). This confining unit possibly consists in part of weathered residuum or saprolite that developed on the bedrock prior to deposition of the Coastal Plain sediments. Other parts of the confining unit consist of fine-grained sediments within the Potomac Formation.

\section{Spatial Relations Among the Aquifers, the Confining Units, and the James River}

As a result of lowering sea level, sediments of the Columbia aquifer deposited in the lowland next to the James River are incised into the older sediments of the Yorktown-Eastover aquifer in the uplands, as well as into the underlying middle Potomac aquifer and confining units (pl. 1). The middle Potomac aquifer is incised in places by the Columbia aquifer and by the channel of the James River. The overlying confining unit was removed by erosion prior to deposition of the Columbia sediments. In addition, present-day dredging of shipping channels has cut through the confining unit to the middle Potomac aquifer.

Section $A-A^{\prime}$ is positioned approximately parallel to the James and Appomattox Rivers (fig. 2), and it is oriented along the dip of the aquifers and confining units (pl. 1). Along section A-A', land surface slopes eastward. The unconfined Yorktown-Eastover aquifer occupies the upland to the west, and the unconfined Columbia aquifer occupies the lowland to the east. The underlying confining units, middle Potomac aquifer, and Piedmont bedrock dip eastward, and they are vertically offset, downwarped, and truncated along the Hopewell-Dutch Gap fault. The fault has been mapped as passing through the southern part of the study area and terminating in the central part just south of the James River (Dischinger, 1987). Confining units that overlie the middle Potomac aquifer have been breached in two places at the James River by (1) Columbia sediments incised along the natural river channel, and (2) a dredged shipping channel. Other confined aquifers and intervening confining units that are present further east pinch-out beneath the eastern edge of the study area.

Section $B-B^{\prime}$ is positioned approximately at a right angle to section $\mathrm{A}-\mathrm{A}^{\prime}$ (fig. 2), and it is oriented along the strike of the aquifers and confining units (pl. 1). Section B-B' crosses the upstream part of the James River in the study area. The unconfined York-
town-Eastover aquifer occupies the uplands to the north and south of the James River. Within the lowland, the unconfined Columbia aquifer occupies a relatively high-elevation terrace to the north of the river and a low-elevation floodplain next to the river. Confining units underlie the Yorktown-Eastover aquifer beneath the uplands separating it from the middle Potomac aquifer. The confining units have been truncated by erosion and deposition of the Columbia sediments, which are incised into the middle Potomac aquifer in the lowland. Similarly, a confining unit within the middle Potomac aquifer appears to pinchout beneath the lowland terrace. The part of the middle Potomac aquifer above this confining unit possibly correlates with the Aquia aquifer further north (T.S. Bruce, Virginia Department of Environmental Quality, oral commun., 1995); although, it is composed of Potomac Formation sediments (appendix 1).

The upstream part of the James River in the study area is incised deeply through the unconfined aquifers, and through the entire thickness of the middle Potomac aquifer to the underlying confining unit (pl. 1, section B-B'). Sediments of the Columbia aquifer occupying the floodplain consist of a veneer overlying the confining unit, and the river channel is cut into the confining unit. Older sediments of the Yorktown-Eastover and middle Potomac aquifers crop out along steep bluffs on both sides of the river, where meander bends have cut into the upland to the south and the lowland terrace to the north. The part of the middle Potomac aquifer on one side of the river is effectively disconnected from the part on the other side. Although supportive well-log data are unavailable, the position of the confining unit near the level of the James River is inferred from (1) dense, cohesive fine sand, silt, and clay in the streambed at seepage site 1 (which differs markedly from coarse-grained, noncohesive streambed sediments at the other seepage sites further downstream), and (2) nearby watersupply-well drilling operations that encountered extensive thicknesses of fine-grained materials (D.L. Nelms, U.S. Geological Survey, oral commun., 1996).

Section $\mathrm{C}-\mathrm{C}^{\prime}$ also is positioned approximately at a right angle to section $\mathrm{A}-\mathrm{A}^{\prime}$ (fig. 2), and oriented along the strike of the aquifers and confining units (pl. 1). Section $\mathrm{C}-\mathrm{C}^{\prime}$ crosses the downstream part of the James River in the study area. The unconfined Yorktown-Eastover aquifer occupies the uplands to the north and south of the James River. Confining units underlie the Yorktown-Eastover aquifer beneath the 
uplands separating it from the middle Potomac aquifer. The unconfined Columbia aquifer occupies lowland terraces, floodplains, and wetlands next to the river, and it is incised into the middle Potomac aquifer. Beneath the upland north of the river, the YorktownEastover aquifer is separated from the middle Potomac aquifer by a thick sequence of confining units.

Beneath the upland south of the river, the YorktownEastover aquifer is separated from the middle Potomac aquifer by a sequence of confining units and other aquifers that are present further southeast and pinchout beneath the southeastern corner of the study area.

The downstream part of the James River in the study area is broader than the upstream part (pl. 1, sections $\mathrm{B}-\mathrm{B}^{\prime}$ and $\mathrm{C}-\mathrm{C}^{\prime}$ ), and it is less deeply incised. Broad low-elevation terraces, floodplains, and wetlands flank both sides of the river. Sediments of the Columbia aquifer are incised into the middle Potomac aquifer at a shallow depth. From the upstream part of the James River to the downstream part, the elevation of the river drops only slightly, but the middle Potomac aquifer dips steeply. As a result, the middle Potomac aquifer is bisected completely by the river in the upstream part, but stretches continuously beneath the river in the downstream part.

\section{Description of Ground-Water-Flow System}

Water levels in wells were compared to determine hydraulic gradients, directions of ground-water flow, aquifer recharge areas, and aquifer discharge areas. Water-level fluctuations in observation wells were examined to infer differences in recharge at different locations, and changes in recharge and discharge over time.

\section{Directions of Ground-Water Flow}

Water levels were measured in observation wells in the study area from August 1995 through July 1996. The approximate elevation, shape, and orientation of the water table was delineated (fig. 4) on the basis of (1) the average water levels in wells open to the unconfined Columbia and Yorktown-Eastover aquifers, (2) the positions of the James and Appomattox Rivers and adjacent wetlands, and (3) the elevations of numerous perennial tributary streams within the study area. The water table was assumed to intersect the land surface at the locations of perennial surface-water bodies. Because vertical hydraulic gradients possibly exist in the aquifers, water levels in individual wells can differ slightly in some cases from the delineated water table. The water table also will fluctuate with seasonal changes in evapotranspiration and during periods of extended precipitation or drought.

The western limit of the unconfined aquifers was designated to coincide with the mapped position of the Fall Line (Mixon and others, 1989). Not included is the westward extension of the water table into the Piedmont, where unconfined water is present primarily in weathered residuum or saprolite developed on bedrock. The water table also is bounded to the northeast and southeast by divides that are assumed to coincide with topographic divides.

Within the unconfined Columbia and YorktownEastover aquifers, the elevation of the water table ranges from more than $160 \mathrm{ft}$ beneath the western upland to approximately sea level near the rivers and wetlands (fig. 4). The slope of the water table indicates the horizontal hydraulic gradient and direction of flow within the unconfined aquifers. The water table slopes generally from the uplands to the lowland and rivers, and it is approximately parallel to the direction of the tributary streams. The horizontal hydraulic gradient is approximately $20 \mathrm{ft} / \mathrm{mi}$ in the western half of the study area. In the eastern half of the study area, the horizontal hydraulic gradient is steeper (approximately $80 \mathrm{ft} / \mathrm{mi}$ ) beneath the northeastern and southeastern uplands, and it is less steep (approximately $10 \mathrm{ft} / \mathrm{mi}$ ) beneath the lowland.

The approximate elevation, shape, and orientation of the potentiometric surface of the middle Potomac aquifer was delineated (fig. 5) on the basis of average water levels in wells open to the aquifer, and the positions of the James and Appomattox Rivers, adjacent wetlands, and sediments of the Columbia aquifer incised into the middle Potomac aquifer. Hydraulic head in the middle Potomac aquifer was assumed to be near sea level in incised areas close to large surface-water bodies.

The potentiometric surface was delineated to represent the areal distribution of head that is vertically averaged across the thickness of the middle Potomac aquifer. Flow-net analyses indicate that the actual head varies vertically within the aquifer, particularly beneath parts of the uplands where downward gradients are large. The actual head also has possibly changed over time. Because vertical hydraulic 


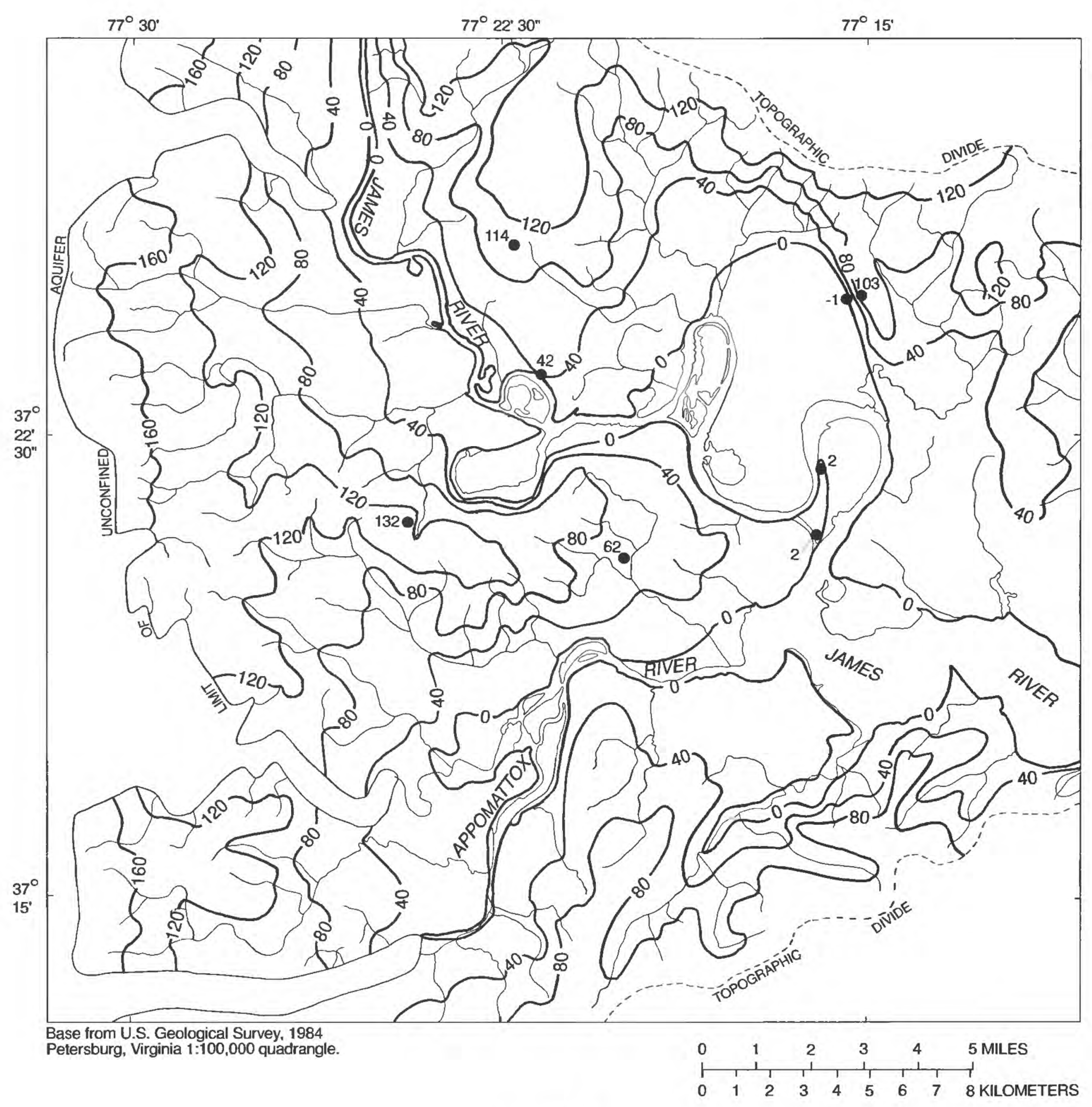

\section{EXPLANATION}

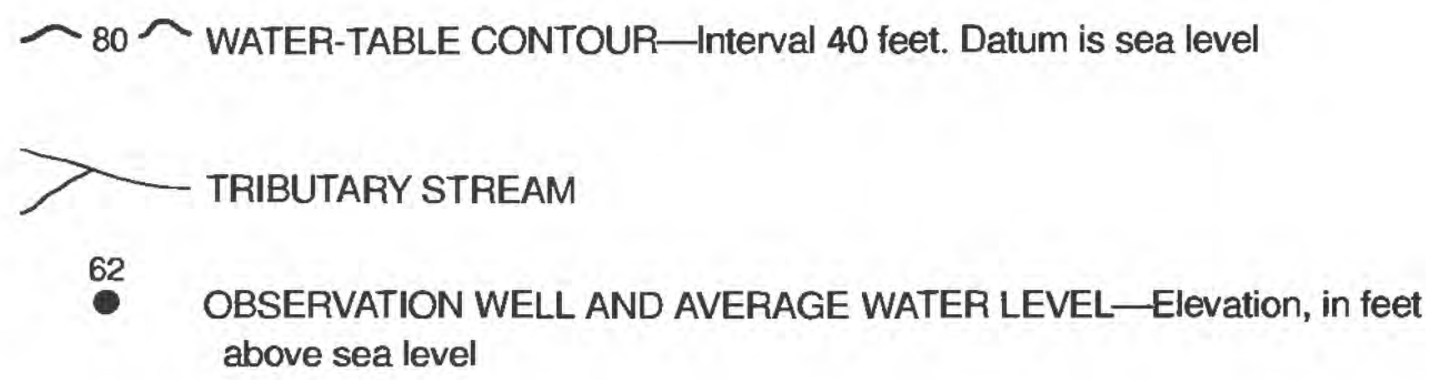

Figure 4. Configuration of the water table in the Fall Zone near Richmond, Virginia. 


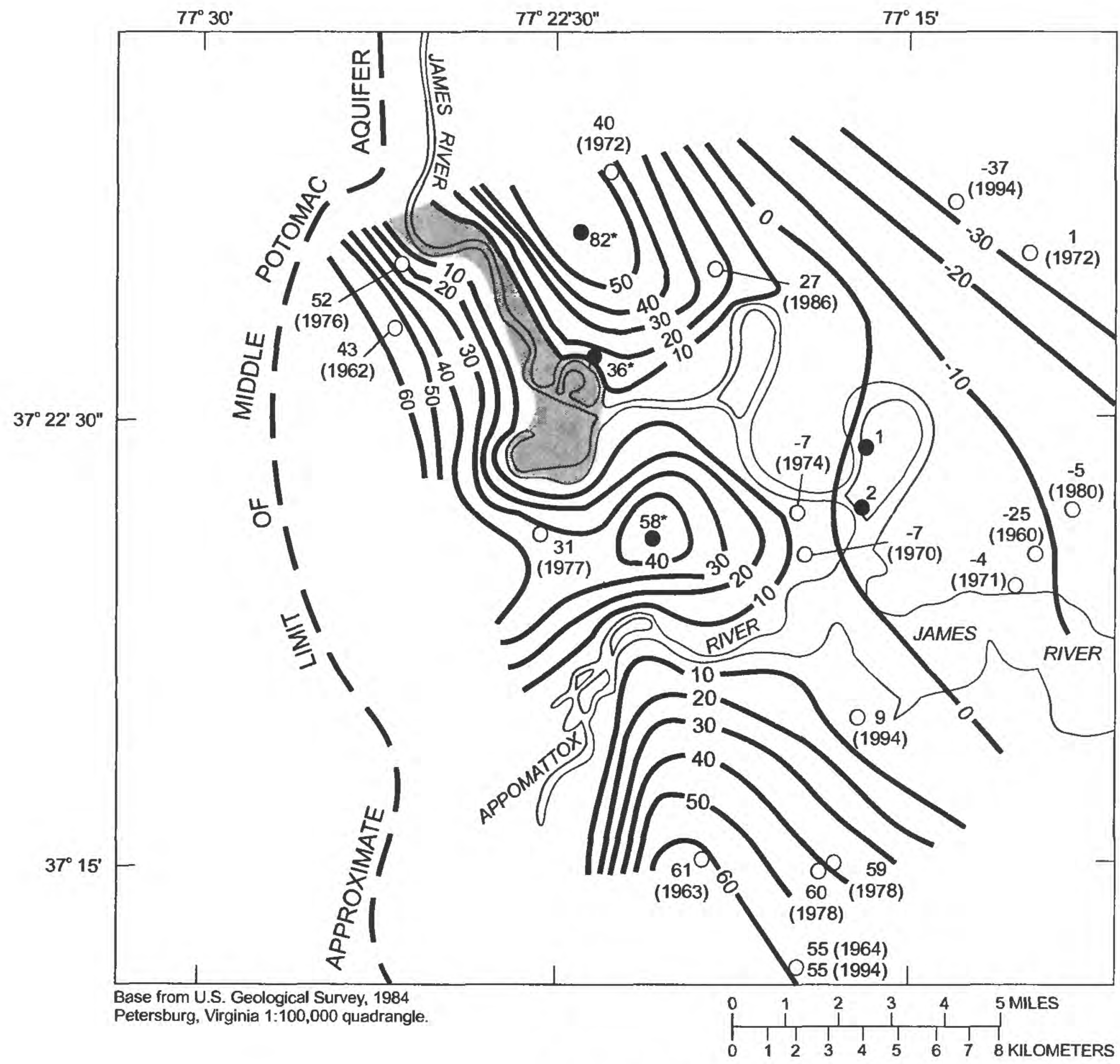

EXPLANATION

MIDDLE POTOMAC AQUIFER REMOVED BY EROSION
$\begin{gathered}\text { POTENTIOMETRIC CONTOUR OF THE MIDDLE POTOMAC AQUIFER- } \\ \text { Interval } 10 \text { feet. Datum is see level }\end{gathered}$
$36^{*}$ OBSERVATION WELL AND AVERAGE WATER LEVEL-Elevation in feet
above sea level: * Denotes large downward gradient
$61,0 \quad \begin{gathered}\text { WATER-SUPPLY WELL AND WATER LEVEL-Elevation in feet above } \\ (1963)\end{gathered}$
sea level. Year of water-level measurement in parenthesis

Figure 5. Potentiometric surface of the middle Potomac aquifer in the Fall Zone near Richmond, Virginia. Water levels in individual wells differ by as much as several feet or more from the potentiometric surface because of vertical hydraulic gradients and changes in head over time. 
gradients are present, and because water-level measurements from water-supply wells span a period of several decades, water levels in individual wells can differ by as much as several feet or more from the delineated potentiometric surface (fig. 5).

The western limit of the middle Potomac aquifer was extrapolated from stratigraphic correlations (pl. 1) and mapped outcrop areas (Mixon and others, 1989). The potentiometric surface, however, was not delineated beyond the well locations. Part of the middle Potomac aquifer was inferred to have been removed by erosion along the upstream part of the James River (fig. 5), where the river has incised through the entire thickness of the aquifer. The Appomattox River to the south probably has not incised the entire thickness of the middle Potomac aquifer because the aquifer is deeper than beneath the James River. The Appomattox River lies to the west of the Hopewell-Dutch Gap fault (fig. 2), where the base of the middle Potomac aquifer has been offset downward (pl. 1, section A-A').

The elevation of the potentiometric surface of the middle Potomac aquifer is greater than $60 \mathrm{ft}$ beneath the western and southeastern uplands, approximately sea level near the rivers and wetlands, and $-30 \mathrm{ft}$ beneath the northeastern upland (fig. 5). The slope of the potentiometric surface indicates the horizontal hydraulic gradient and direction of flow within the middle Potomac aquifer. From the western and southeastern uplands, the potentiometric surface slopes toward the lowland and the rivers. From the northeastern upland, however, the potentiometric surface primarily slopes to the northeast and away from the river. A potentiometric divide separates part of the northeastern upland from the upstream part of the James River.

Directions of vertical hydraulic gradients between and within the unconfined Columbia and Yorktown-Eastover aquifers and the confined middle Potomac aquifer were determined from water levels in observation wells. In the uplands (fig. 6), vertical hydraulic gradients generally are downward. Within the Yorktown-Eastover aquifer, wells $51 \mathrm{G} 6$ and $51 \mathrm{G}$ 7 exhibit a downward hydraulic potential of approximately $6 \mathrm{ft}$. Similarly, downward hydraulic potentials between the Yorktown-Eastover aquifer and middle Potomac aquifer are approximately $31 \mathrm{ft}$ between wells $52 \mathrm{H} 16$ and $52 \mathrm{H} 17$, and $3 \mathrm{ft}$ between wells $52 \mathrm{G}$ 22 and 52G 23. Within some parts of the middle Potomac aquifer, however, vertical hydraulic gradients possibly are small: wells $52 \mathrm{G} 23$ and $52 \mathrm{G} 24$ exhibit a hydraulic potential of near zero.

Water levels in observation wells located in the lowland (fig. 7) indicate that vertical hydraulic gradients are downward but generally are of smaller magnitude than in the uplands. Within the Columbia aquifer, downward hydraulic potentials only are a few tenths of a foot or less between wells $52 \mathrm{H} 12$ and $52 \mathrm{H} 13$, and wells 52G 27 and 52G 28. Similarly small downward hydraulic potentials between the Columbia and middle Potomac aquifers are exhibited by wells $52 \mathrm{G}$ 25 and 52G 26, and wells 52G 28 and 52G 29.

The largest vertical hydraulic potential observed in the lowland is approximately $6 \mathrm{ft}$ downward between the Columbia and middle Potomac aquifers exhibited by wells $52 \mathrm{H} 14$ and 52H 15 (fig. 7). These wells are located in an area designated as part of the lowland, for the purpose of classifying the landscape of the study area (fig. 2). This part of the lowland includes a high-elevation terrace, however, and possibly represents conditions that are transitional between the uplands and low-elevation floodplains.

The principal direction of ground-water flow through the unconfined and confined aquifers probably is horizontal through much of the study area. Because the aquifers consist of stratified sediments, horizontal hydraulic conductivities probably are much greater than vertical hydraulic conductivities (Harsh and Laczniak, 1990). Parts of the study area in which vertical gradients are large have a corresponding potential for vertical flow. The magnitude and direction of flow that actually takes place, however, depends on both the vertical and horizontal hydraulic conductivities of the aquifers and confining units, and on their threedimensional configurations and boundaries. An accurate estimate of the magnitude and direction of flow requires some form of quantitative analysis.

\section{Relations Between Recharge and Discharge}

Locations where ground water enters, flows through, and is discharged from the study area were identified, and the magnitude and effects of groundwater withdrawal were evaluated. Changes in recharge and discharge over time were described.

\section{Spatial Relations}

Directions of ground-water flow through the study area were delineated and represented schematically (pl. 1), on the basis of directions of vertical and 

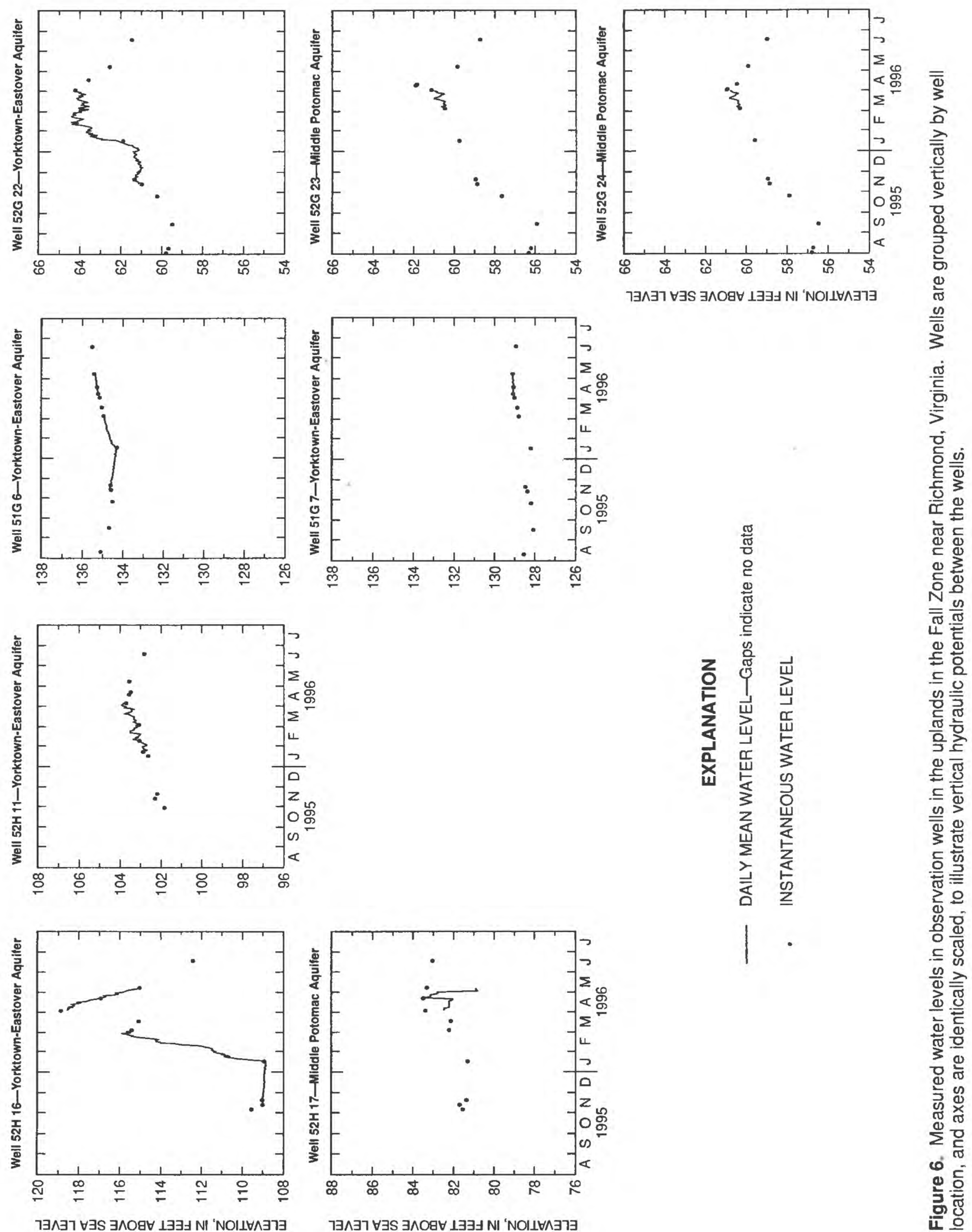

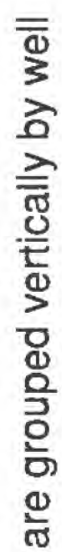
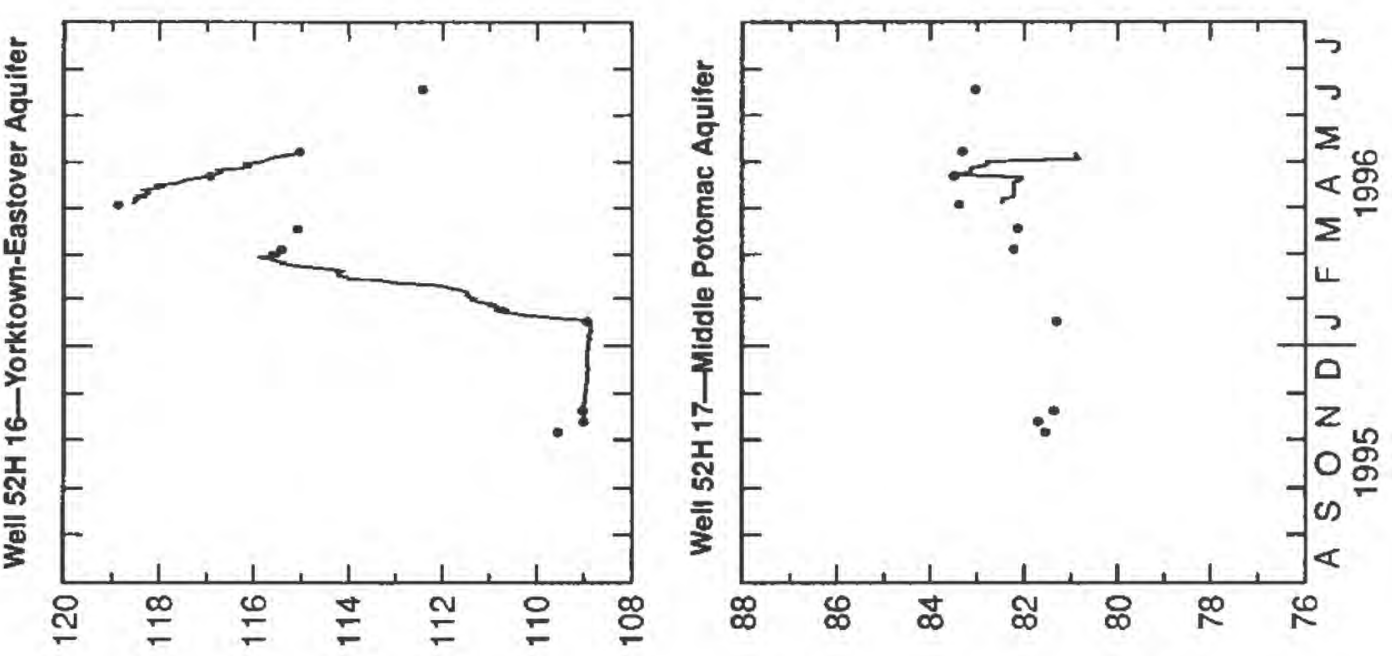

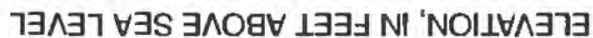

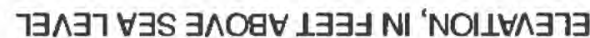



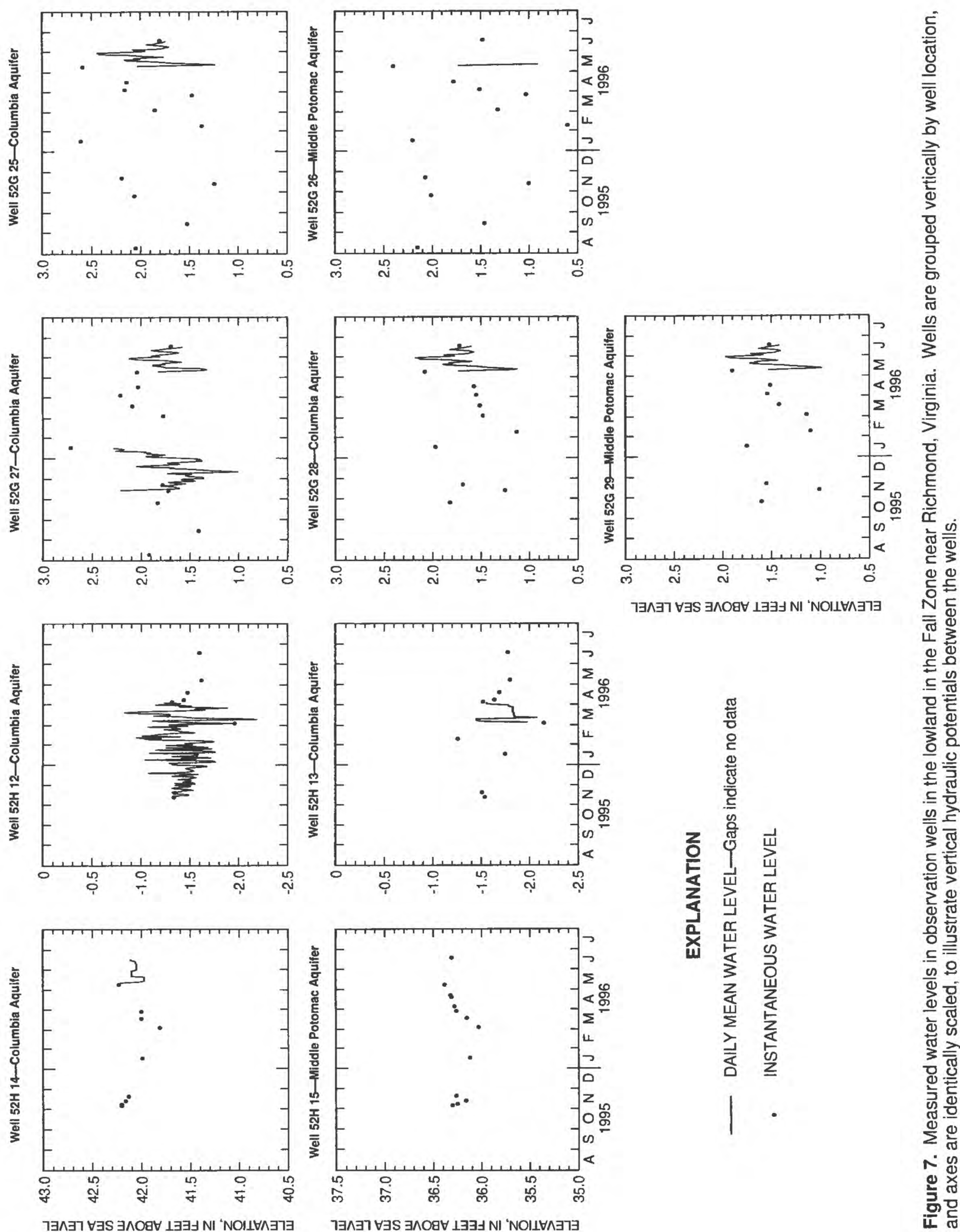

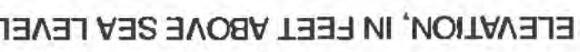

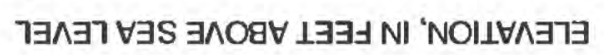

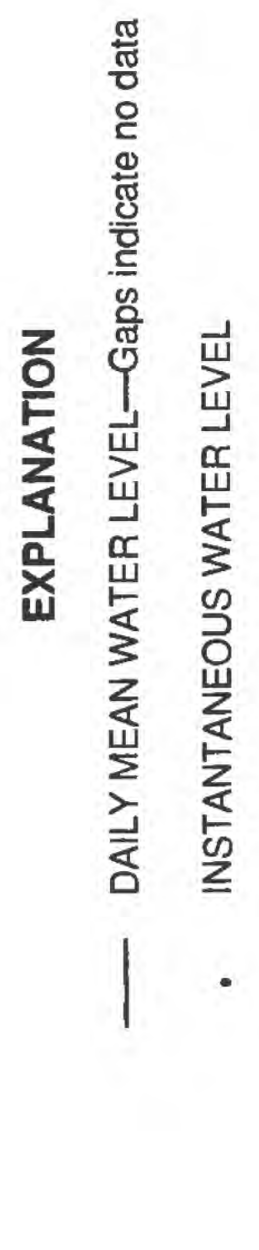


horizontal hydraulic gradients (see section "Directions of Ground-Water Flow"). The positions of the James and Appomattox Rivers, adjacent wetlands, Columbia sediments incised into the middle Potomac aquifer, and perennial tributary streams also were considered in depicting the general direction of ground-water flow.

The water table is positioned in the unconfined Columbia and Yorktown-Eastover aquifers (pl. 1), at depths below land surface from near sea level at low elevations to more than $140 \mathrm{ft}$ above sea level beneath the uplands. The water table intersects the land surface along the James River and adjacent wetlands, and at locations along tributary streams. The water table slopes from the uplands to the lowland and river, and it is truncated in places by scarps along which are numerous perennial springs and seeps.

Water enters the unconfined aquifers as recharge at the water table. Precipitation that infiltrates the land surface and is not removed by evapotranspiration percolates through the unsaturated zone to the water table. Evapotranspiration in the humid-temperate climate of the study area probably is greater than half of the amount of water supplied by precipitation (Rasmussen and Andreasen, 1959; Johnston, 1976). Of the remainder, a small part does not infiltrate but runs off the land surface directly to streams. The areally average rate at which water reaches the water table is approximately $10 \mathrm{in} / \mathrm{yr}$ (Richardson, 1994).

From the water table, much of the water flows short distances through the unconfined aquifers and discharges to tributary streams where the water table converges on these streams (fig. 4), or directly to the James and Appomattox Rivers and adjacent wetlands. Because of the large density of tributary streams, most of the ground water probably is intercepted by and discharged to these streams before reaching the rivers or wetlands. In addition, a large number of small watersupply wells probably withdraw water from the unconfined aquifers throughout the study area. The total amount of this withdrawal is unknown, but much of it is probably returned to the aquifers through septic systems.

Some of the water in the unconfined Columbia and Yorktown-Eastover aquifers does not discharge to the surface but leaks through the underlying confining units to recharge the confined middle Potomac aquifer (pl. 1). Without quantitative analysis, however, the proportion of the total flow through the study area that enters the middle Potomac aquifer is uncertain. Head in the middle Potomac aquifer, however, is highest, and recharge probably is greatest, in three parts of the aquifer (fig. 5): (1) beneath the western upland, (2) beneath part of the southeastern upland near the Appomattox River, and (3) along the margin of the northeastern upland near the upstream part of the James River. Recharge is facilitated in these areas by large downward gradients between the unconfined and confined aquifers.

The middle Potomac aquifer also is recharged possibly by a small amount of water that discharges from the underlying bedrock. In the Piedmont, ground water is present in fractures in bedrock that possibly extend beneath Coastal Plain sediments in the Fall Zone. The amount of water that flows, however, from the bedrock into overlying sediments probably is small. Most ground-water flow in the Piedmont takes place at depths within $30 \mathrm{ft}$ below land surface, possibly along high-permeability zones between weathered residuum or saprolite and the shallow bedrock (Harned, 1989). Less flow probably takes place in deeper bedrock that extends beneath the Coastal Plain. In addition, flow in bedrock is localized along fractures that - in most cases - do not extend areally more than a few hundred feet, or remain open below shallow depths (Richardson, 1980).

From recharge areas in the western upland, southeastern upland, and along the margin of the northeastern upland near the upstream part of the James River, ground water flows through the middle Potomac aquifer toward the James and Appomattox Rivers (pl. 1 and fig. 5). Beneath most of the northeastern upland, ground water flows through the middle Potomac aquifer largely to the northeast and away from the rivers. A flow divide separates part of the northeastern upland from the James River.

Some water in the middle Potomac aquifer discharges to the James and Appomattox Rivers. Without quantitative analysis, however, the proportion of the flow that discharges to the rivers is uncertain. The upstream part of the James River is incised through the entire thickness of the aquifer (pl. 1, section B-B'). Discharge to the river is facilitated by numerous perennial seeps and springs along the steep bluffs bordering this part of the river, effectively lowering the head in the aquifer next to the river and inducing a large hydraulic gradient from the adjacent uplands (fig. 5). Similarly, discharge is promoted along the downstream part of the river by incision of the river channel and the unconfined Columbia aquifer through 
the confining unit and into the middle Potomac aquifer (pl. 1, sections $\mathrm{A}-\mathrm{A}^{\prime}$ and $\mathrm{C}-\mathrm{C}^{\prime}$ ), providing a conduit between the aquifer and river. Incision is much shallower than upstream, however, and almost the entire thickness of the middle Potomac aquifer extends beneath the river. Part of the flow through the aquifer possibly is not intercepted by the river and continues out of the study area in downgradient directions toward northeast and east.

As with the unconfined aquifers, some water also is removed from the confined middle Potomac aquifer by water-supply wells within the study area. The largest industrial and municipal withdrawals of ground water in Virginia are reported to DEQ in order to comply with regulatory requirements. During 1990 (the latest year for which withdrawal data have been organized in sufficient detail for this analysis), the rate of reported withdrawal in the study area totaled 403,000 gal/d, all from the middle Potomac aquifer. Individual withdrawal amounts are reported by the well owners, and their accuracy is uncertain. In addition, withdrawal during the study period could be greater than that reported during 1990 because of continuing development in the study area.

Assuming that recharge to the unconfined aquifer is $10 \mathrm{in} / \mathrm{yr}$, the reported withdrawal from the middle Potomac aquifer is approximately 1 percent of total recharge. Because the amount of flow that enters the middle Potomac aquifer is uncertain, however, the percentage of the flow through the middle Potomac aquifer that is removed from the aquifer by the reported withdrawal also is uncertain. Additional smaller unreported withdrawals probably are also made from the middle Potomac aquifer. The total amount of this unreported withdrawal is unknown, but some of it probably is returned to the unconfined aquifers through septic systems.

In addition to withdrawals within the study area, wells at locations outside the study area possibly remove some water from the middle Potomac aquifer that originates from within the study area. Some of the water in the middle Potomac aquifer flows through the aquifer and out of the study area in downgradient directions to the northeast and east (pl. 1 and fig. 5), thereby providing a source of recharge to the regionalscale aquifer system. The regional hydraulic gradient in the middle Potomac aquifer in Virginia generally is eastward, but is locally diverted northeastward toward an area several miles north of the study area (Hammond and others, 1994). The gradient is the result of regionally coalescing cones of depression caused by large ground-water withdrawals that supply industrial facilities ((Meng and Harsh, 1988). These withdrawals possibly intercept ground water from the study area that originated as recharge to the middle Potomac aquifer. In addition, the withdrawals possibly intercept water that recharged the water table from part of the Columbia aquifer adjacent to the northeastern upland. Water levels in wells $52 \mathrm{H} 12$ and $52 \mathrm{H} 13$ generally are between -1 and $-2 \mathrm{ft}$ below sea level (fig. 7), suggesting that the withdrawal-induced water-level decline could extend from the middle Potomac aquifer into the overlying Columbia aquifer. These water levels probably were not lowered as a result of evapotranspiration because the water table is approximately $40 \mathrm{ft}$ below the land surface at this location.

\section{Temporal Relations}

Fluctuations in water levels measured in observation wells during the study period indicate differences in the timing and effect of recharge in different parts of the study area. In the uplands, distinct seasonal trends in water levels in wells open to the unconfined Yorktown-Eastover aquifer (fig. 6) indicate that recharge to the water table occurs primarily during the cold part of the year, including fall, winter, and early spring. At this time of year, evapotranspiration is at a minimum because the air temperature is low and plant growth is dormant. Consequently, some of the precipitation that infiltrates the land surface is not returned to the atmosphere but percolates to the water table. The rate of recharge is greater than the rate of discharge to streams or downward leakage, and the excess water is stored, causing water levels to rise. By late spring, evapotranspiration has increased enough to return most of the infiltrating water to the atmosphere before it reaches the water table. Continued discharge and downward leakage are supplied by water taken out of storage, causing water levels to decline.

Rises in water levels in the middle Potomac aquifer approximately coincided with recharge to the water table in the Yorktown-Eastover aquifer (fig. 6). Detailed examination of water-level data indicated that the rises generally occurred within 2 days or less of specific recharge events. Leakage to the middle Potomac aquifer possibly increases on a seasonal basis in concert with water-table recharge. When watertable recharge ceases in late spring, leakage to the middle Potomac aquifer also is possibly reduced, and 
water levels in observation wells open to the middle Potomac aquifer begin to decline.

In the lowland, water levels fluctuate over a small range and, with the exception of wells $52 \mathrm{H} 14$ and $52 \mathrm{H} \mathrm{15}$, do not exhibit distinct seasonal trends (fig. 7). Precipitation infiltrates the land surface in the lowland, as in the uplands, and percolates to provide recharge at the water table. The unweathered and noncohesive aspects of the recently deposited sediments of the Columbia aquifer result in large hydraulic conductivities (table 1), which in turn result in minimal water-level changes. As a result, the water table is virtually flat throughout much of the Columbia aquifer (pl. 1). Small horizontal hydraulic gradients are adequate to move large amounts of water through the aquifer to discharge locations. Water levels rise for only brief periods in response to specific recharge events (fig. 7) but quickly decline as the temporary increase in hydraulic gradient dissipates. Short-term air entrapment in the unsaturated zone during infiltration of water possibly also results in rapid water-level rises that subsequently dissipate quickly (Freeze and Cherry, 1979).

Wells $52 \mathrm{H} 14$ and 52H 15 occupy a high-elevation terrace within the lowland (pl. 1, section B-B') and they exhibit a muted seasonal water-level trend (fig. 7). As previously discussed, this terrace possibly represents conditions that are transitional between the uplands and low-elevation floodplains.

As in the uplands, the timing and magnitude of water-level changes and leakage into the middle Potomac aquifer in the lowland possibly is a function of recharge to the water table. Because the water table in the lowland fluctuates over only a small range and rises only temporarily in response to recharge, so do water levels in wells open to the middle Potomac aquifer (fig. 7). Detailed examination of water-level data indicated that water levels in the middle Potomac aquifer rose almost instantaneously with recharge to the water table in the Columbia aquifer, possibly because the intervening confining unit is either thin or absent (pl. 1).

Water-level fluctuations in some observation wells in the lowland indicate complex flow interactions with the James River. Wells 52G 25, 52G 26, $52 \mathrm{G} 27,52 \mathrm{G} \mathrm{28}$, and 52G 29 are located within a few hundred feet of the James River (fig. 2). A tide gage was operated temporarily on the river near the wells. Detailed examination of gage records indicated that water levels in these wells fluctuate systematically with tidal fluctuations of the James River (fig. 8). Similar effects have been recognized in other tidally influenced areas (Freeze and Cherry, 1979). The James River fluctuated more than $3 \mathrm{ft}$ during the approximately 12-hour tidal cycle, while water levels in wells fluctuated only about $1 \mathrm{ft}$. In addition, the water levels in wells lag behind the river water level by 1 to 2 hours. Vertical gradients are downward between the Columbia aquifer and underlying middle Potomac aquifer, as indicated by water levels in wells $52 \mathrm{G} 25$ and $52 \mathrm{G} 26$, and wells $52 \mathrm{G} 28$ and $52 \mathrm{G} 29$. The vertical gradient within the Columbia aquifer, however, varies from being downward following low tide to near zero following high tide, as indicated by water levels in wells 52G 28 and 52G 29.

Water-level fluctuations in observation wells open to the Columbia and middle Potomac aquifers near the James River result from changes in stress between sediment grains caused by external loading from the river. As the river stage rises toward high tide, added weight is placed on the aquifers and compresses the sediment grains, thereby decreasing pore space between the grains and increasing hydraulic pressure. Water levels then rise as water flows into the wells. The effect is nearly instantaneous within the aquifer (Freeze and Cherry, 1979), but is observed to lag by 1 to 2 hours in the wells (fig. 8) because of the low efficiency with which water enters the wells. A relatively large amount of water is required to enter the well to produce the water-level rise, compared to the volume of water between sediment grains.

Hydraulic pressure apparently is increased more near the base of the Columbia aquifer (well 52G 28) than at the water table (well 52G 27), thereby reducing the downward hydraulic gradient through the aquifer to almost zero. As the river stage then declines toward low tide, the weight is removed and sediment grains are decompressed, pores expand, and hydraulic pressure decreases. Water levels then decline as water flows out of the wells. Hydraulic pressure decreases more near the base of the Columbia aquifer (well 52G 28 ) than at the water table (well 52G 27), thereby inducing a downward hydraulic gradient through the aquifer.

Fluctuations in the direction and magnitude of horizontal hydraulic gradients between the observation wells and the James River indicate that the direction of ground-water flow between the wells and the river also fluctuates. Horizontal gradients between the wells and the James River vary from being toward the 

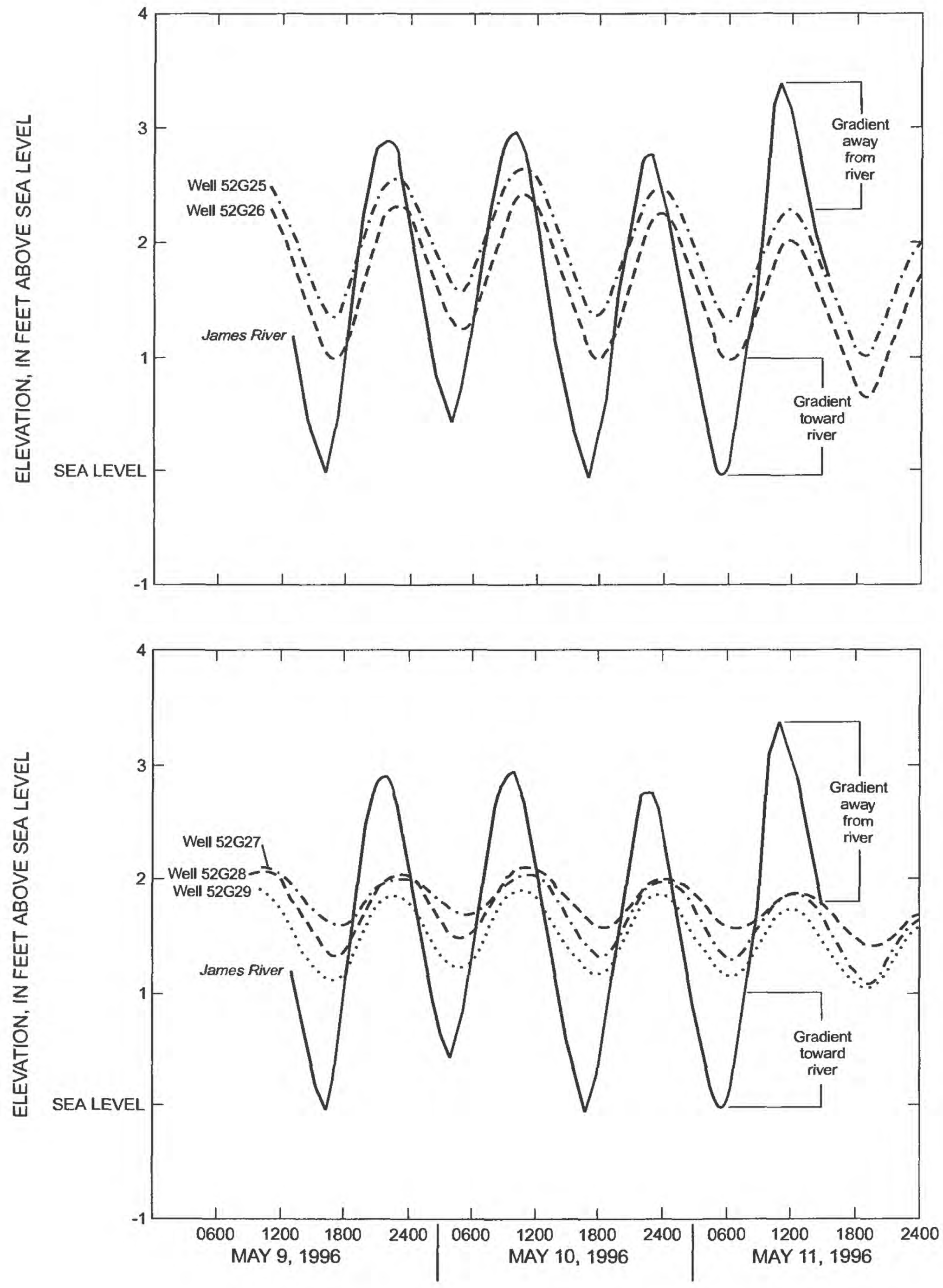

Figure 8. Measured water levels in observation wells in the floodplain and tidal fluctuations of the James River in the Fall Zone near Richmond, Virginia. 
river at low tide to away from the river at high tide (fig. 8). During the lower tidal cycle, ground water flows toward and is discharged into the river. During the upper tidal cycle, however, water flows from the river toward the wells. As the river stage rises toward high tide, the exposed sides of the river channel and adjacent wetlands are inundated, and flow is induced into a streambank-storage zone next to the river. As the river stage then declines toward low tide, the previously inundated areas are exposed, allowing the streambank-storage zone to drain back to the river. As a result, the streambank-storage zone contains a mixture of ground water and river water that oscillates laterally toward and away from the river with each tidal cycle. Hydraulic gradients appear to be slightly greater during the draining stage than the inundating stage (fig. 8), and the net long-term direction of flow is probably toward the river. Thus, ground water that originated as recharge to the water table at locations away from the river probably is entrained with river water during the draining stage, resulting in a net discharge of ground water to the river.

\section{ANALYSIS OF GROUND-WATER FLOW}

Ground-water flow in the study area was quantitatively represented by a mathematical-numerical model. Saturated flow was simulated by using MODFLOW, a modular three-dimensional finite-difference ground-water-flow model (McDonald and Harbaugh, 1988). The description of the ground-water-flow system presented in the section "Hydrogeologic Framework" formed the basis for design of the model.

Quantitative representation provides a means to evaluate the accuracy and consistency of the flowsystem description. The simulated spatial routing of water in subsurface pathways through the study area was consistent with observed conditions. Simulated ground-water traveltimes were consistent with ground-water ages determined from concentrations of chlorofluorocarbons, or CFC's, analyzed in groundwater samples, and indicated that water takes approximately 50 years to flow from the water table to the unconfined aquifers and into the confined aquifer.

Simulated flow rates indicated that 94 percent of the ground water discharges within the study area from the unconfined aquifers to the James and Appomattox Rivers, adjoining wetlands, and tributaries. Less water ( 11 percent) leaks downward into the confined aquifer, approximately half of which flows back upward to discharge at the surface. Of the water that remains in the confined aquifer, approximately 17 percent is withdrawn from wells and the rest provides recharge to regional aquifers.

\section{Simulation of Ground-Water Flow}

Ground-water flow can be described mathematically by partial differential equations that cannot be solved exactly except for very simple systems. The finite-difference model consists of a series of algebraic equations that approximately describe ground-water flow between specified aquifer subsections or cells. A grid of square cells scaled to $5,080 \mathrm{ft}$ along each side was superimposed on a topographic map of the study area to divide the aquifers into discrete cells (fig. 9). The hydraulic characteristics of the aquifers, any sources or sinks of water other than flow from adjacent cells, and an initial approximation of hydraulic head are specified for each cell.

The model area is defined by boundaries along which conditions of flow or hydraulic head are specified. Using iterative calculations, a computer program of the model simultaneously solves the series of equations for the hydraulic head and the rate and volume of ground-water flow in each aquifer cell. The strongly implicit procedure was used to solve the equations.

\section{Model Design and Boundary Conditions}

The ground-water-flow system in the study area is complex. The characteristics of the flow system described earlier were used to define boundary conditions, which allow the flow system to be translated into a comparatively simple form for mathematical simulation. The model area was defined by lateral and vertical hydraulic boundaries using the conventions of Franke and others (1987).

The ground-water-flow model contains two layers (fig. 10)-an upper layer that represents both the Columbia and Yorktown-Eastover aquifers under unconfined conditions, and a lower layer that represents the middle Potomac aquifer under confined conditions. Small parts of other confined aquifers that pinch-out beneath the eastern and southern edges of the study area are not represented in the model. Vertical, lateral, and internal boundaries of both layers were defined to correspond to observed conditions. The elevation of the top of the upper layer was designated by the water table, which was simulated as a fluctuating 


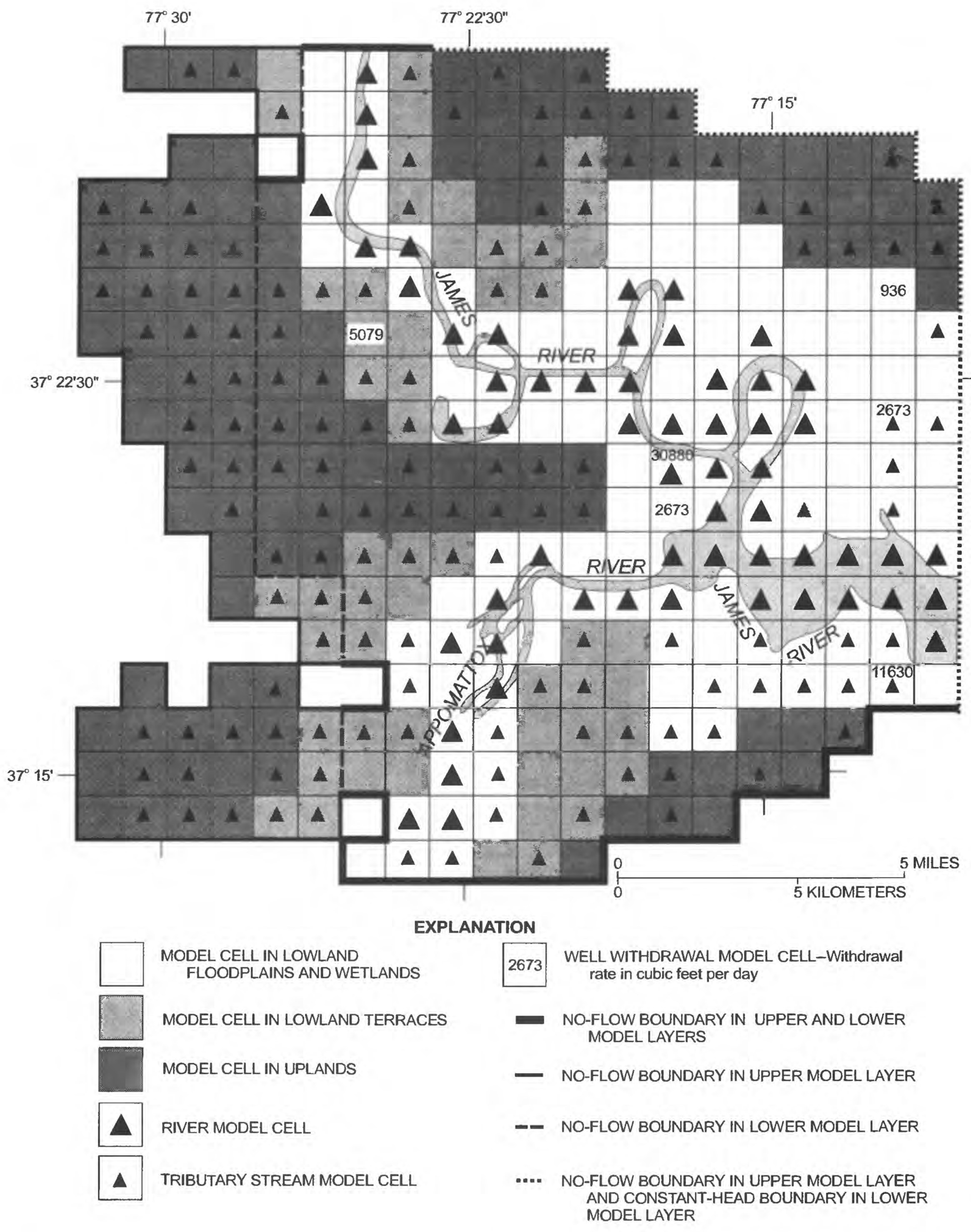

Figure 9. Design features of the ground-water-flow model in the Fall Zone near Richmond, Virginia. 


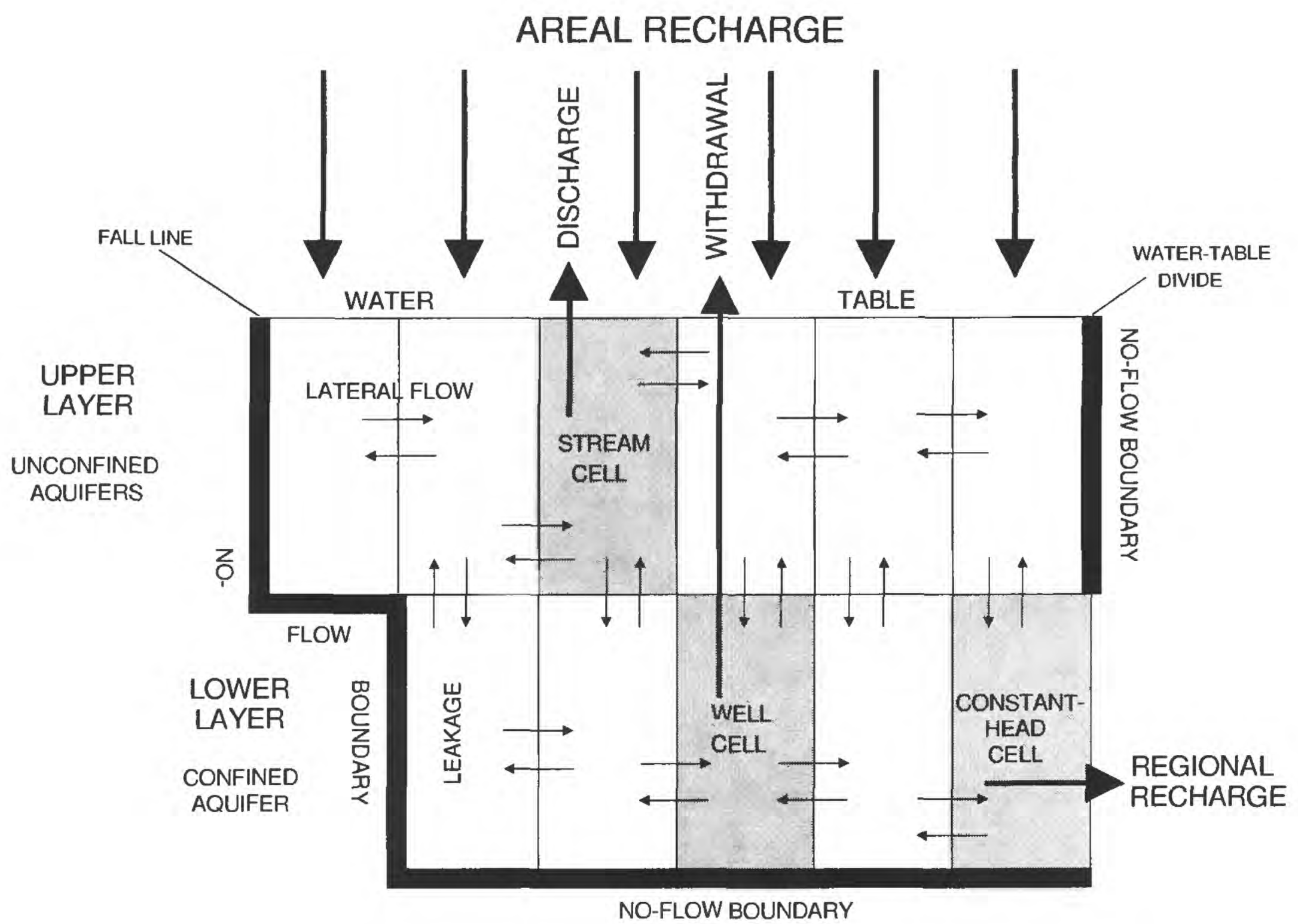

Figure 10. Conceptualized ground-water-flow system in the Fall Zone near Richmond, Virginia.

free surface in the unconfined aquifers. The lower layer is bounded at its base by a no-flow boundary, which corresponds to the confining unit and bedrock underlying the middle Potomac aquifer.

The westward extent of the unconfined aquifers lies along the Fall Line in the western part of the study area (fig. 4). The unconfined aquifers are further bounded laterally by water-table divides in the northeastern and southeastern parts of the study area, which are assumed to coincide with topographic divides. Unconfined ground water flows primarily from the Fall Line and water-table divides toward the James and Appomattox Rivers. Accordingly, no-flow boundaries were specified along the western, northeastern, and southeastern sides of the upper model layer to correspond with the Fall Line and water-table divides (figs. 9 and 10). The remaining sides of the upper layer correspond to parts of the unconfined aquifers adjacent to the upstream part of the James River toward the northwest, and the downstream part toward the east, and also were specified to have no-flow boundaries.
The direction of unconfined ground-water flow next to the James River was inferred from the observed water table (fig. 4) to be toward the river and oriented approximately perpendicular to the river. Thus, noflow boundaries were specified along the sides of the upper layer that are perpendicular to the James River (fig. 9).

The westward extent of the confined middle Potomac aquifer lies approximately 2 to 3 mi east of the Fall Line in the western part of the study area (fig. 5). Accordingly, a no-flow boundary was specified along the western side of the lower model layer to correspond with the aquifer limit (fig. 9). The westernmost part of the upper layer that is not underlain by the lower layer is bounded at its base by a no-flow boundary (fig. 10), which corresponds to bedrock underlying the unconfined aquifer.

The northwestern and southern sides of the lower layer were specified to have no-flow boundaries coincident with the upper layer, and that correspond to parts of the middle Potomac aquifer next to the 
upstream part of the James River toward the northwest, and between the Appomattox and James Rivers toward the south (fig. 9). The direction of confined ground-water flow was inferred from the observed potentiometric surface (fig. 5) to be toward the rivers and oriented approximately perpendicular to the rivers. Thus, no-flow boundaries were specified along the sides of the lower layer that are perpendicular to the rivers.

Confined ground water leaves the study area partly by flowing through the subsurface to the northeast and east to recharge regional aquifers. Accordingly, a constant-head boundary was specified along the northeastern and eastern sides of the lower layer (figs. 9 and 10). Head values assigned to constant-head cells along the boundary correspond to the observed elevation of the potentiometric surface (fig. 5). The simulated volume and rate of discharge across the boundary can fluctuate but head remains constant.

Unconfined ground water is discharged within the study area to the James and Appomattox Rivers, adjoining wetlands, and tributary streams. Accordingly, head-dependent flow cells (stream cells) were specified in the upper layer to correspond to the rivers, wetlands, and tributaries (figs. 9 and 10). The simulated volume and rate of discharge through the stream cells can fluctuate, and are a function of the simulated difference between head in the aquifer and the stream stage, and of the specified conductance of streambed material within the cells.

Confined ground water is removed within the study area partly by withdrawal from water-supply wells. Accordingly, withdrawals were specified for cells in the lower model layer that correspond to the locations of water-supply wells reported to DEQ during 1990 (figs. 9 and 10). Withdrawal rates of individual wells located in the same cell were summed and represent the withdrawal for the cell. The simulated head and the volume and rate of flow through the cells can fluctuate but the rate of withdrawal remains constant.

All ground water that enters the model area is simulated as areal recharge at the water table in the unconfined aquifers (fig. 10). From the water table, water flows laterally through the unconfined aquifers and leaks downward into the confined middle Potomac aquifer. Water also can leak upward from the confined aquifer into the unconfined aquifers. Ground water leaves the model area as either (1) flow from the confined aquifer across the constant-head boundary,
(2) discharge from the unconfined aquifers to the James and Appomattox Rivers, adjoining wetlands, and tributaries, or (3) withdrawal from the confined aquifer by water-supply wells.

\section{Model Calibration}

After model boundaries were defined, hydrologic data were input to the model computer program, and the program was executed to output data that represented the ground-water-flow system in the study area. Input data were based initially on field-measured values, to the extent possible. Measured values, however, were not available for all inputs required by the model, and values for unmeasured inputs had to be selected from within realistic ranges on the basis of the types and distributions of subsurface materials in the study area. In addition, the field-measured values are only estimates made at the point of measurement and possibly are not appropriate, effective values to mathematically represent the flow system at the scale at which the model is constructed (Cooley and Naff, 1990). Therefore, some input values were adjusted within realistic ranges during repeated executions of the model program. No further adjustments to the input values were made when simulated heads were within several feet, or less, from actual heads estimated from water levels measured at corresponding areal locations in the study area.

Ground-water flow in the study area was simulated under steady-state conditions. Steady-state simulations provide static representations of the flow system that indicate a nonchanging spatial distribution of flow. Mathematical representations of steady-state ground-water flow generally consist of systems of equations that relate input values for (1) hydraulic head, (2) volumetric flow rate, and (3) hydraulic conductivity or transmissivity. If two of the input values are known, the equations can be solved for the third value. Field-based measurements or estimates were made for all three input values, but different sources and degrees of error are associated with each measurement or estimate.

Hydraulic head is estimated usually from measurements of water levels in wells open to an aquifer. Generally, water levels can be measured accurately to within a hundredth of a foot. Wells open at different depths at a single areal location, however, often exhibit different water levels because of vertical hydraulic gradients in the aquifer. In contrast, modelsimulated hydraulic head for a single layer represents 
a vertically constant value (Cooley and Naff, 1990). If vertical gradients in the aquifer are large, accurate simulation may require the aquifer to be divided into more than one layer. Conversely, if vertical gradients are small relative to horizontal gradients, the aquifer can be simulated as a single layer in which average head is estimated from measured water levels.

Vertical gradients between the unconfined aquifers and the confined middle Potomac aquifer in the study area are significant (figs. 6 and 7). Therefore, separate model layers were used to represent the unconfined and confined aquifers. Water levels in wells open to the unconfined and confined aquifers were used to estimate the average head in the upper and lower layers, respectively.

Because recharge is the only source of water to the study area, the volumetric flow rate is equal to the rate of recharge. Estimates of recharge were not obtained within the study area. Estimates of net annual ground-water recharge from other, similar areas are approximately 10 in/yr (McFarland, 1995; Richardson, 1994). These estimates represent net recharge that is discharged subsequently to streams, but they do not include water that is removed from the aquifer by evapotranspiration. The estimates could differ from recharge within the study area by several inches per year.

Transmissivity, the capacity of the aquifer to transmit water, is equivalent to the horizontal hydraulic conductivity multiplied by aquifer thickness. Values for transmissivity are input directly to the model to represent aquifers under confined conditions. For aquifers under unconfined conditions, the saturated thickness and, hence, the transmissivity differs with changes in the position of the water table. Therefore, values of horizontal hydraulic conductivity are input to the model to represent aquifers under unconfined conditions. Transmissivity is then calculated in the computer code by multiplying hydraulic conductivity by the saturated thickness that results from the position of the water table.

The hydraulic properties of aquifer materials generally are heterogeneous. Consequently, estimates of hydraulic conductivity are valid only at the scale at which the estimates are made (Bradbury and Muldoon, 1990). Appropriate use of hydraulicconductivity estimates depends on the size of the area to be analyzed and the volume of aquifer material of interest. Specifically for calibration of a ground-waterflow model, hydraulic property values are appropri- ately input that are representative of the aquifer at the scale at which the model is constructed.

The degree to which estimates of horizontal hydraulic conductivity based on slug-test results represent the study area for simulation of ground-water flow is uncertain. Slug-test results generally indicate conditions only within the proximity of the wells. Also, because the hydraulic properties of the aquifers probably are heterogeneous, a significantly large range of hydraulic-conductivity values was obtained for each aquifer (table 1).

In addition to the slug tests, aquifer pumping tests were conducted by Henrico County at well $52 \mathrm{H}$ 10 (fig. 2), results of the latter test indicated a transmissivity for the middle Potomac aquifer of approximately 9,500 (gal/d)/ft (H. Wigglesworth, County of Henrico Public Utilities, written commun., 1990). Given the thickness of the aquifer estimated at the pumping test location to be approximately $70 \mathrm{ft}$, the hydraulic conductivity that corresponds to the pumping-test estimate of transmissivity is $19 \mathrm{ft} / \mathrm{d}$, which is greater than the estimates of hydraulic conductivity based on slug-test results (table 1).

Pumping tests impose larger hydraulic stresses within the aquifer than slug tests and, hence, effectively average small-scale heterogeneities in hydraulic properties and provide estimates that represent a much larger volume of the aquifer. The pumping test at well $52 \mathrm{H} 10$ possibly is not representative of the entire study area, but it does indicate that the hydraulic conductivity of the middle Potomac aquifer can be significantly greater than estimated by slug tests. Large-scale estimates of hydraulic conductivity generally are larger than small-scale estimates (Bradbury and Muldoon, 1990).

Of the three values that are related by mathematical representations of steady-state ground-water flow, the estimates of hydraulic head and volumetric flow rate (as recharge) probably are more accurate as input values to the model than hydraulic conductivity/ transmissivity. Therefore, a uniform areal recharge rate of $10 \mathrm{in} / \mathrm{yr}$ was specified across the model area. Transmissivity of the confined middle Potomac aquifer was specified as the thickness of the aquifer $(0 \mathrm{ft}$ near the Fall Line to approximately $200 \mathrm{ft}$ beneath the southeastern upland) multiplied by a hydraulic conductivity of $10 \mathrm{ft} / \mathrm{d}$, a value roughly midway between the slug-test and pumping-test estimates. Hydraulic conductivities of the unconfined aquifers were then adjusted during repeated executions of the model 
program until simulated heads in each model layer (figs. 11 and 12) were within several feet, or less, from actual heads estimated from water levels measured at corresponding areal locations (figs. 6 and 7). Because simulated heads do not vary vertically within a single model layer, they do not precisely equal measured water levels at all corresponding areal locations.

In order to account for different horizontal hydraulic conductivities and saturated thicknesses within the unconfined aquifers, cells in the upper model layer are differentiated to represent the lowland that contains the Columbia aquifer and the uplands that contain the Yorktown-Eastover aquifer (fig. 9). Cells in the upper layer that represent the lowland area are further differentiated to distinguish terraces from floodplains and wetlands. Different hydraulic and physical characteristics were specified in the model for the different types of cells in the upper layer (table 2). Hydraulic-conductivity values were specified on the basis of relative differences in horizontal hydraulic conductivity indicated by slug-test results (table I). Differences in the elevation of the base of the upper layer were on the basis of differences in the elevation of the base of the Columbia and Yorktown-Eastover aquifers (pl. 1).

Published estimates of the horizontal hydraulic conductivities and (or) their corresponding transmissivities for the Columbia, Yorktown-Eastover, and middle Potomac aquifers (Harsh and Laczniak, 1990; Hamilton and Larson, 1988; Laczniak and Meng, 1988) were compared to those obtained for this study. The published horizontal-hydraulic-conductivity values for the Columbia and Yorktown-Eastover aquifers generally range between 15 to $20 \mathrm{ft} / \mathrm{d}$, and for the middle Potomac aquifer are approximately $50 \mathrm{ft} / \mathrm{d}$. The published estimates differ considerably from the slugtest values for this study (table 1), but are consistent with the model calibration input values (table 2). The published estimates were interpolated across either the entire Coastal Plain in Virginia, or major regionalscale parts of it, and were based on aquifer pumping tests.

The two-layer model simulates vertical flow between the unconfined aquifers and the confined middle Potomac aquifer. Therefore, a model input to represent conditions of vertical flow is required. Although horizontal hydraulic conductivity and transmissivity are input to the model computer program, the vertical hydraulic conductivity of each layer is not specified. Instead, vertical leakance is specified to represent the conductance of water between model layers. Vertical leakance is based on a thickness-weighted average of the vertical hydraulic conductivities of adjacent layers. Estimates of vertical hydraulic conductivity were not obtained within the study area. Therefore, vertical leakance values were selected initially from within realistic ranges and adjusted during calibration.

The cells in the upper model layer that were differentiated to account for different horizontal hydraulic conductivities and saturated thicknesses within the unconfined aquifers (fig. 9), also were used to account for different vertical leakances between the unconfined aquifers and the confined middle Potomac aquifer (table 2). Vertical leakance values were based on differences in the thickness of confining units underlying the Columbia and Yorktown-Eastover aquifers (pl. 1).

Vertical leakance values that range over two orders of magnitude (table 2) resulted in simulated differences in head between the two layers that approximate measured water-level differences between the unconfined and confined aquifers. Similarly, the thicknesses of the confining units that separate the unconfined and confined aquifers range from $0 \mathrm{ft}$ to approximately $150 \mathrm{ft}$. The vertical leakance values used in this study are similar to the upper range of

Table 2. Model calibration input values assigned to cells in the upper layer that represent different parts of the unconfined Columbia and Yorktown-Eastover aquifers in the Fall Zone near Richmond, Virginia

\begin{tabular}{lccc}
\hline $\begin{array}{c}\text { Model } \\
\text { cell }\end{array}$ & $\begin{array}{c}\text { Horizontal hydraulic } \\
\text { conductivity } \\
\text { (feet per day) }\end{array}$ & $\begin{array}{c}\text { Aquifer bottom } \\
\text { elevation } \\
\text { (feet) }\end{array}$ & $\begin{array}{c}\text { Vertical leakance } \\
\text { (per day) }\end{array}$ \\
\hline Uplands & 12 to 36 & 30 to 80 & $5 \times 10^{-5}$ to $1 \times 10^{-4}$ \\
Lowland terraces & 12 to 36 & -40 to -10 & $1 \times 10^{-4}$ to $2 \times 10^{-4}$ \\
Lowland floodplains & 120 & $1 \times 10^{-4}$ to $1 \times 10^{-3}$ \\
\hline
\end{tabular}




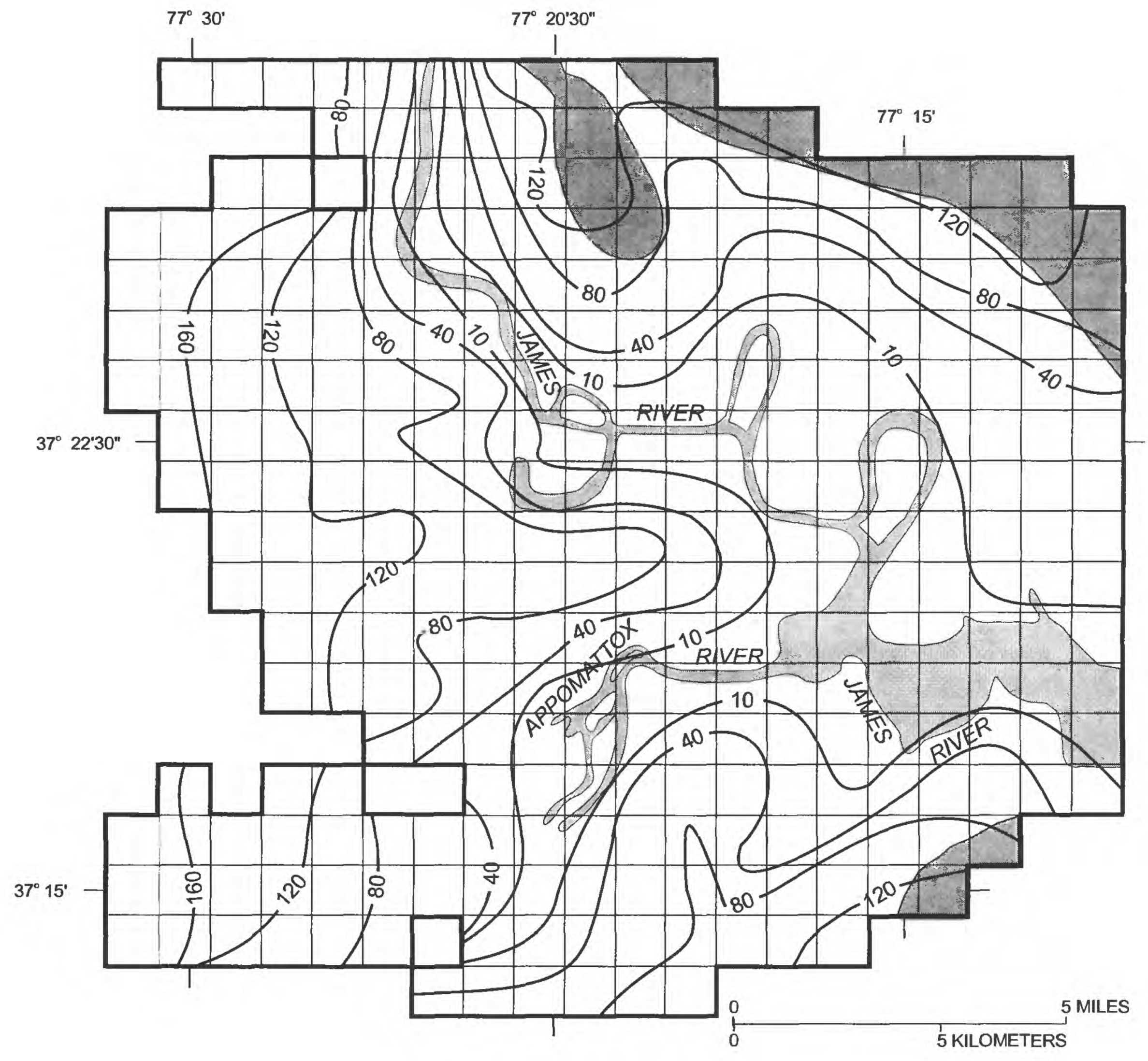

EXPLANATION

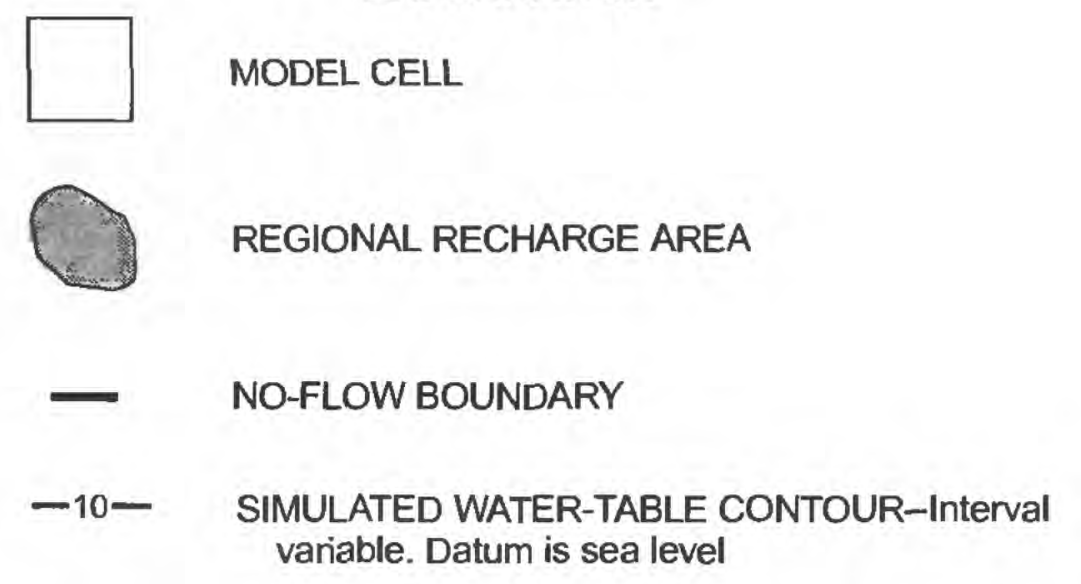

Figure 11. Simulated configuration of the water table in the upper layer that represents the unconfined Columbia and Yorktown-Eastover aquifers in the Fall Zone near Richmond, Virginia. 


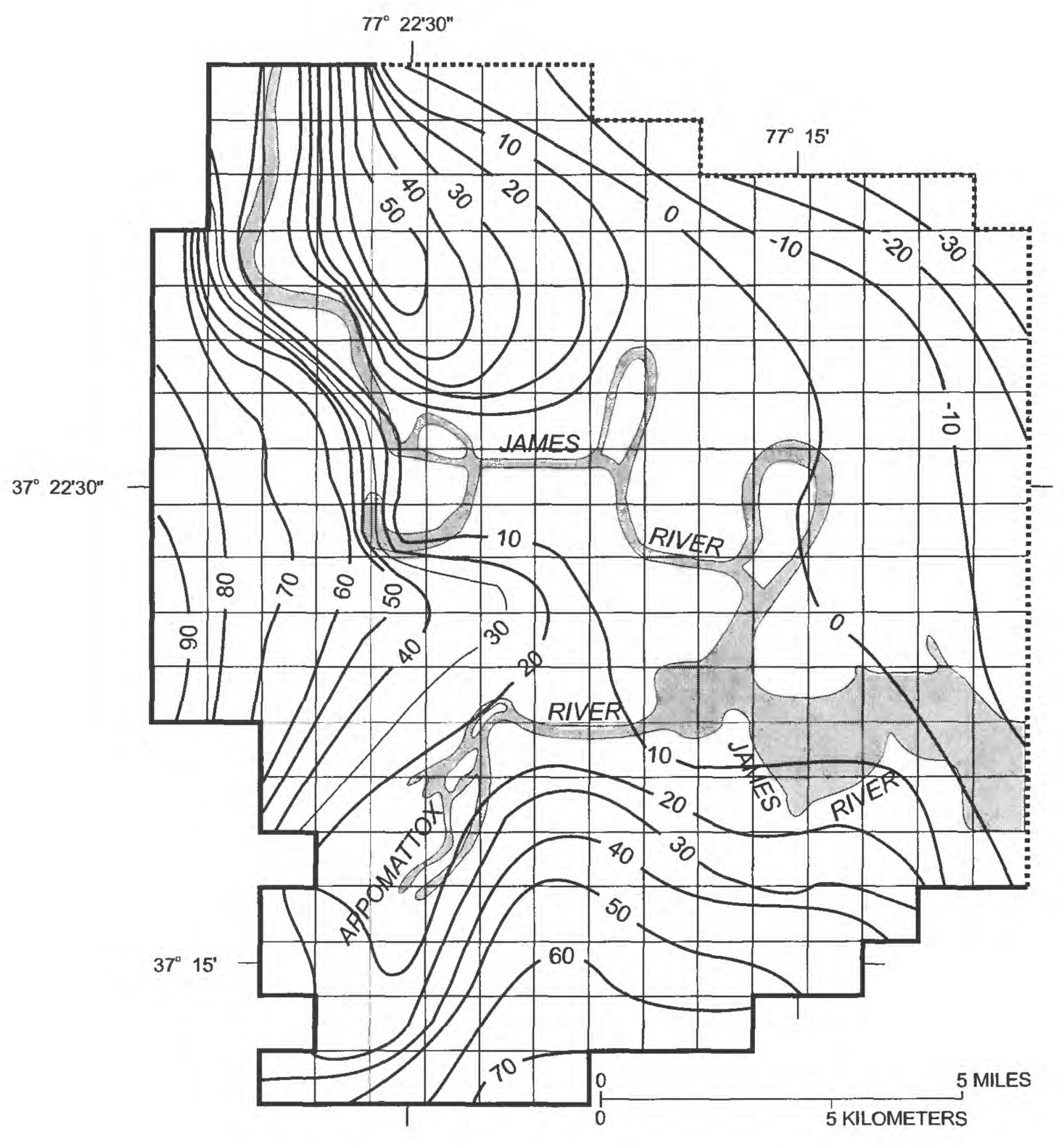

EXPLANATION

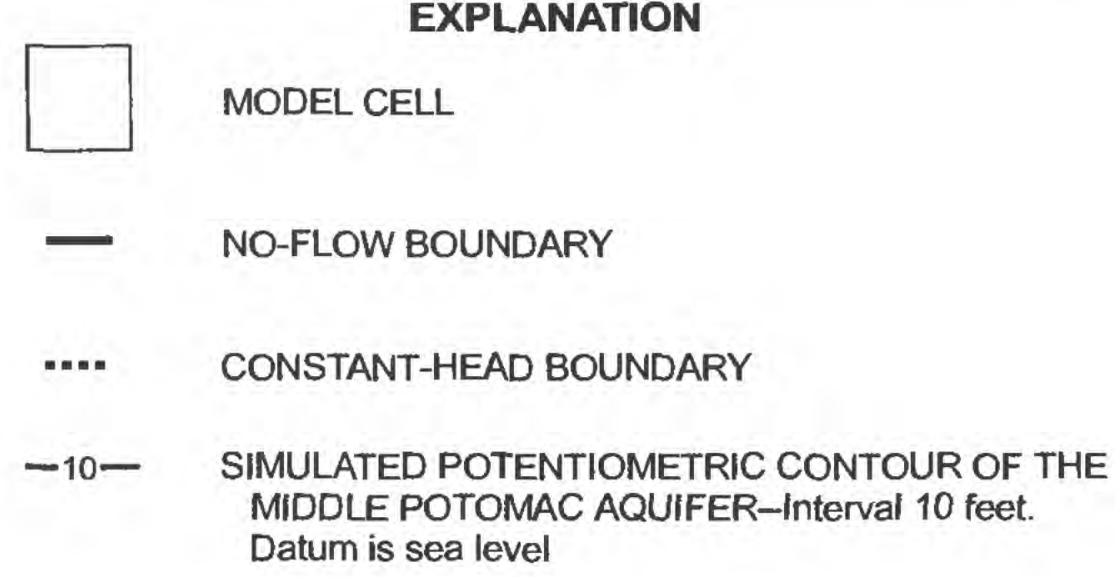

Figure 12. Simulated potentiometric surface of the lower layer that represents the confined middle Potomac aquifer in the Fall Zone near Richmond, Virginia. 
published values for previous studies in the Virginia Coastal Plain (Harsh and Laczniak, 1990; Hamilton and Larson, 1988; Laczniak and Meng, 1988). Vertical leakance likely is greater in the Fall Zone than elsewhere in the Coastal Plain because confining units generally are thinner than in areas further east.

Ground water is discharged from the upper model layer through head-dependent flow cells (stream cells) that correspond to the James and Appomattox Rivers, adjoining wetlands, and tributaries (fig. 9). The amount of discharge is determined by the simulated difference between the head in the aquifer and the stage of the stream, and the specified conductance of streambed material. Cells representing the rivers and wetlands were assigned a stream-stage value of sea level, the approximate elevation of the river surface. Because of tides, the actual river stage fluctuates by a small amount compared to the differences in head across the study area, and the tidal effect on flow was assumed to be negligible. Cells representing the tributaries were assigned stream-stage values that correspond to the approximate elevations of the tributaries in each cell.

The conductance of the streambed material depends on the geometric configuration of the streambed (length, width, and thickness within each model cell), and its vertical hydraulic conductivity, according to the relation

$$
C=\frac{K L W}{M},
$$

where

$C$ is conductance, in square feet per day,

$K$ is vertical hydraulic conductivity, in feet per day,

$L$ is length, in feet,

$W$ is width. in feet, and

$M$ is thickness, in feet.
Several assumptions were made on which to base streambed conductance values. Because the size of the rivers and wetlands generally is large compared to the model cells, the streambed was assumed to entirely overlie the aquifer throughout each of the stream cells that correspond to the rivers and wetlands. Estimates of the vertical hydraulic conductivity of the streambed were made at some of the seepage site locations along the James River (fig. 2). On the basis of vertical hydraulic-gradient measurements made in conjunction with seepage measurements (table 3 ), a vertical hydraulic conductivity value of $1 \mathrm{ft} / \mathrm{d}$ was assumed for the streambed for the model. The thickness of the streambed is unknown but was assumed to be $10 \mathrm{ft}$. On the basis of these assumptions, a streambed conductance of $2.6 \times 10^{6} \mathrm{ft}^{2} / \mathrm{d}$ was assigned to stream cells that correspond to the rivers and wetlands. Stream cells that correspond to the tributaries were assigned one tenth of that value $\left(2.6 \times 10^{5} \mathrm{ft}^{2} / \mathrm{d}\right)$, because the tributaries occupy smaller areas and probably have thinner streambeds.

\section{Model Sensitivity and Limitations}

The degree of uncertainty in the model inputs was evaluated by determining the sensitivity of simulated heads to changes in the value of each input. The model program was executed repeatedly while the value of each input was individually changed in fixed increments by as much as an order of magnitude above and below the calibration value. The root-mean-square error was calculated from differences between simulated heads and average measured water levels for each execution, and plotted with the multiplication factor used incrementally to change the model input

Table 3. Streambed seepage rate and vertical hydraulic conductivity in the James River near Richmond, Virginia [nm, not measured; $\mathrm{ft}$, feet; $\mathrm{ft} / \mathrm{d}$, foot per day; for location of sites, see figure 2]

\begin{tabular}{|c|c|c|c|c|}
\hline Site number & $\begin{array}{c}\text { Distance from } \\
\text { shore } \\
\text { (ft) }\end{array}$ & $\begin{array}{l}\text { Measurement } \\
\text { duration } \\
\text { (hours) }\end{array}$ & $\begin{array}{l}\text { Seepage } \\
\text { rate } \\
(\mathrm{ft} / \mathrm{d})\end{array}$ & $\begin{array}{c}\text { Vertical hydraulic } \\
\text { conductivity } \\
(\mathrm{ft} / \mathrm{d})\end{array}$ \\
\hline 1 & 25 & 25.8 & 0.15 & $\mathrm{~nm}$ \\
\hline I & 41 & 23.8 & .006 & $\mathrm{~nm}$ \\
\hline 1 & 41 & 23.8 & .015 & $\mathrm{~nm}$ \\
\hline 2 & 26 & 22.3 & .0 & $\mathrm{~nm}$ \\
\hline 3 & 12 & 23.2 & .38 & 1.7 \\
\hline 3 & 45 & 23.2 & .20 & .70 \\
\hline 4 & 11 & 3.0 & .12 & 2.1 \\
\hline 4 & 11 & 23.2 & .039 & 1.0 \\
\hline 4 & 20 & 23.2 & .024 & 1.2 \\
\hline
\end{tabular}


value (fig. 13). A curve was then fitted through the points resulting from the change of each input.

All of the curves pass through a point with a multiplication factor of 1 (fig. 13), which represents the calibration value. The calibration value produced the least difference between simulated heads and measured water levels, and the smallest root-mean-square error. Changes of input values that produced large differences between simulated heads and measured water levels plot as steep curves. The results of the simulation are strongly dependent on the certainty with which these input values were estimated. Changes of input values that produced small differences between simulated heads and measured water levels plot as gently sloping curves. The certainty with which these input values were estimated is not critical because they do not strongly affect model results.

Changes in input values for recharge rate and hydraulic conductivity of the upper layer produced the largest changes in simulated head (fig. 13). Therefore, only small changes in recharge rate and hydraulic conductivity values input to the model can be representative of the study area, so long as the other inputs are held constant. The curve produced by changing values for recharge rate is a mirror image of the hydraulic conductivity curve. Increasing the recharge rate is equivalent to decreasing hydraulic conductivity, and simulation results are equally dependent on the degree of certainty with which recharge rate and hydraulic conductivity were estimated. Increasing hydraulic

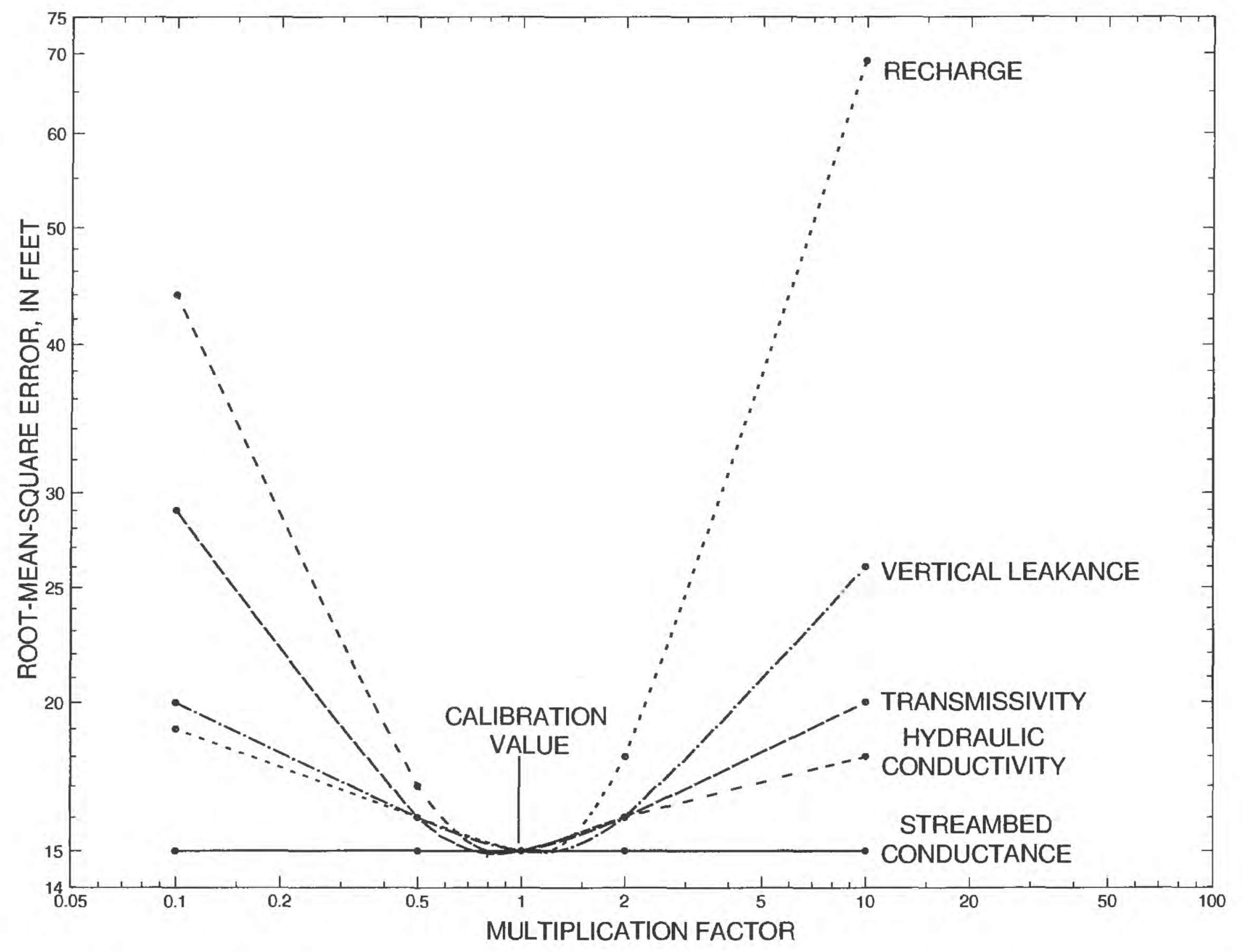

Figure 13. Sensitivity of simulated heads to changes in values of hydraulic properties input to the ground-water-flow model. 
conductivity or decreasing recharge rate "flattens" hydraulic gradients and the water table, and results in lower heads. The stream cells impose a lower limit on heads. Decreasing the hydraulic conductivity or increasing recharge rate steepens hydraulic gradients and the water table and causes a rise in heads, which do not have an upper limit.

Compared to recharge rate and hydraulic conductivity of the upper layer, changes in vertical leakance and transmissivity input values of the lower layer produced smaller changes in simulated heads (fig. 13). Therefore, larger changes in vertical leakance and transmissivity values input to the model can be representative of the study area, so long as the other inputs are held constant. Similar to recharge rate and hydraulic conductivity, the curve produced by changing values for vertical leakance is a mirror image of the transmissivity curve. Increasing vertical leakance is equivalent to decreasing transmissivity, and simulation results are equally dependent on the degree of certainty with which vertical leakance and transmissivity were estimated.

Changes in streambed conductance input values produced the smallest changes in simulated head (fig. 13). Therefore, a large change in streambed conductance values input to the model can be representative of the study area, so long as the other inputs are held constant.

As in all finite-difference ground-water-flow models, a single unique mathematical solution cannot be obtained to solve the system of equations that represent ground-water flow. The set of calibration model-input values represents only one point within a continuum of possible input-value sets. For example, a different value for recharge rate than that used here could be input to the model, from which corresponding values for the other inputs could be obtained during calibration, so as to result in the same simulated heads in the model layers as were produced here. The results of the model are dependent on the assumption that appropriate effective values were input to the model that represent the ground-water-flow system in the study area.

The model also provides only an approximate representation of the flow system. Unreported well withdrawals and septic-system return flows probably are small but are undocumented and possibly numerous, and are not represented in the model. Because small parts of aquifers that pinch out beneath the eastern and southern margins of the study area are not included in the model design, flow to or from these aquifers also is not represented. In addition, because only a steady-state simulation was performed, changes in flow over time are not represented. The rate of discharge to wetland areas is likely to vary daily, seasonally, and yearly in response to fluctuations in evapotranspiration rate related to changing climatic conditions. Withdrawal rates also probably vary over time, but only the reported yearly average rate during 1990 is represented in the model.

The model was constructed to address the objectives for this particular study and, at best, is representative of the study area only under the conditions existing during the study period. Other applications of the model probably would have limited validity and could produce erroneous results. Any interpretations based on the results of the model are directly dependent on the assumptions and limitations described above.

\section{Distribution of Ground-Water Flow}

In order to evaluate the accuracy of the description of the ground-water flow system in the study area, (see section "Hydrogeologic Framework") data that were input to and output from the ground-water-flow model, and additional field data, were used to examine the spatial distribution and rates of flow in the aquifers. Simulated directions of flow within the model area were compared to directions of flow in the study area that were inferred as part of the flow-system description. In addition, the time required for ground water to flow through different parts of the study area, and the magnitudes of different components of flow, were estimated. Possible relations among the different components of flow were examined.

\section{Directions and Traveltimes of Ground-Water Flow}

Because the areal distribution of simulated heads in the model layers (figs. 11 and 12) generally resembles the areal distribution of observed water levels in the aquifers (figs. 4 and 5), horizontal directions of simulated ground-water flow are consistent with those presented in the flow-system description. The simulated direction of flow in the upper unconfined aquifer layer generally is from parts of the layer that correspond to the uplands toward parts that correspond to the rivers and adjoining wetlands. The simulated direction of flow in the lower confined aquifer layer is 
partly from the uplands toward the rivers and wetlands, and partly toward the northeast and away from the rivers.

Vertical ground-water flow simulated by the model also was examined by using particle-tracking procedures. Flow paths through the model layers were calculated with the computer program MODPATH (Pollock, 1989). Flow paths were designated to originate from each model cell, starting from the watertable surface, and their directions were calculated to their eventual discharge locations. Vertical sections of the model that correspond approximately to those on which the flow system description was based (pl. 1) were examined. Simulated vertical flow paths through the model layers generally are consistent with vertical flow directions through the aquifers presented in the flow-system description. The direction of simulated flow through the upper unconfined aquifer layer is partly lateral from upland areas toward the lowland area, and partly downward beneath the uplands. The direction of simulated flow through the lower confined-aquifer layer is lateral, partly from beneath the uplands toward the lowland, and partly from beneath the northeastern upland toward the northeast.

Particle-tracking procedures were further used to estimate the amount of time required for water to flow through the aquifers in the study area. Timeseries particle distributions were calculated by using MODPATH (Pollock, 1989). Particles were designated to originate from each model cell, starting from the water-table surface, and their positions within the ground-water-flow system were calculated at successive time increments as they were simulated to be transported along flow paths. Particle spatial distributions were plotted and contoured at different time increments to infer simulated traveltimes of ground water through different parts of the flow system (pl. 1).

Simulated particle transport velocity is partly a function of the porosity of subsurface materials, which is unknown in the study area. Because the subsurface materials observed in drilling samples and in outcrops are generally poorly sorted, a relatively low porosity value of 25 percent was assigned throughout the simulated ground-water-flow system. A larger porosity value would result in a slower transport velocity, and a smaller porosity value would result in a faster transport velocity.

Assuming a ground-water age of 0 years at the water table, particle tracking indicated that ground water takes approximately 10 years to flow through most of the upper unconfined aquifer layer. but as much as 50 years to reach parts of its base (pl. 1). Within the lower confined aquifer layer, $\mathrm{g}^{\text {round water }}$ takes approximately 50 years to reach par's of the layer near its top, to as long as 1,000 years to reach the base of the layer at its downgradient end toward the east.

Additional estimates of ground-water traveltimes through different parts of the study area were made by analyzing water samples collected from observation wells for concentrations of ch'orofluorocarbon compounds, or CFC's, which act a` environmental tracers. CFC's have been steadily increasing in the atmosphere and other parts of the environment as the use of these compounds has become widespread during the past few decades. The technique used to collect ground-water samples for CFC anclysis (Busenberg and Plummer, 1992) allows $\mathrm{C}^{\circ} \mathrm{C}$ concentrations to be related to the amount of time that has elapsed since the water entered the water table as recharge. Ground-water ages in the study area were inferred from analyzed concentrations of CFC-11 (trichlorofluoromethane), CFC-12 (dichlorodifluoromethane), and CFC-113 (trichlorotrifluoroethane).

Comparison of CFC ground-water ages to the positions of open observation-well intervals from which the samples were collected (pl. 1) irdicates that the ages range from 0 years at the shallow wells to 50 years at the deepest well. Shallow wells are completed at depths near the water table and are expected to produce young ground water. Deeper wells intercept longer flow paths along which water has moved for greater periods of time since originating at the water table.

Several factors can affect CFC ages. The analytical precision of CFC ages is plus or minus 2 years. Different ages for a particular sample, however, are often indicated by the three CFC compounds (CFC-11, CFC-12, and CFC-113). Depending on conditions at the well location, the concentrations of the compounds can be affected differently by extraneous contamination and (or) chemical degradation. Concentrations of samples collected in the study area that were believed to have been so affected were disregarded in interpreting ground-water ages.

The apparent age of a ground-water sample reffects the mixing of ground water of difforent ages. As water moves along flow paths, it is mix ed by dispersion with water from adjacent flow paths. The degree of dispersion usually is difficult to estimate, 
and is unknown in the study area, but is a function of the hydraulic properties of subsurface materials. Paths of water molecules moving through sediment pores differ in length on a microscopic scale. In addition, hydraulic properties can be heterogeneous on a small scale, and flow velocities can differ over small areas. Thus, a given volume of water in the aquifer will consist of molecules with different traveltimes. The extent of mixing increases in the downgradient direction as water molecules are dispersed along their flow paths.

The CFC ground-water ages are generally consistent with the ground-water traveltimes indicated by particle-tracking analysis (pl. 1). Accounting for possible extraneous affects on the CFC concentrations, and recognizing that the ages represent mixed samples, the CFC ages generally corroborate the particletracking analysis and, hence, the overall design and calibration of the model. Thus, the CFC age estimates provide an additional description of the ground-waterflow system in the study area that was obtained independently of the ground-water-flow model, and which indicates that the model is consistent with the flowsystem description.

\section{Rates of Ground-Water Flow}

In order to infer relations between the localscale flow system within the study area and the regional-scale flow system, rates of ground-water flow into, through, and out of the aquifers were calculated. Comparisons were made among flow rates of water that leaves the model area by (1) discharging from the upper unconfined aquifer layer through head-dependent cells (stream cells) representing the James and Appomattox Rivers, adjoining wetlands, and tributaries; (2) discharging from the lower confined aquifer layer to simulated withdrawal wells; and (3) flowing through the lower layer across the constant-head boundary to the northeast and east to recharge regional aquifers.

In steady-state simulations, conditions of flow do not change over time and there is no net change in the amount of water stored in the aquifers. Therefore, the rate at which water was specified to enter the flow system as recharge represents the total simulated flow rate, and equals the sum of the rates at which water leaves the flow system (table 4). In order to be directly comparable. both recharge and discharge flow rates are normalized for the model area in units of inches per year. Percentages of the rates of the total flow as recharge also were calculated. Because separate layers were used in the model to represent the unconfined and confined aquifers, vertical leckage rates also were calculated to determine the exchange of water between the layers.

The total simulated flow rate of water entering the model area was specified as $10 \mathrm{in} / \mathrm{yr}$ of recharge at the water table in the upper unconfined aquifer layer (table 4). From the water table, most of the ground water flows laterally through the upper layer and discharges to the surface, but a small amount leaks downward into the lower confined aquifer layer. Almost half of the water that leaks downward into the lower layer flows back upward into the upper layer, and it is added to the total discharge to the surface.

Rates of ground-water discharge also were estimated from rates of streambed se spage (table 3 ) measured at four locations along the James River (fig. 2). For comparison to the measured seepage rates, the simulated rate of discharge to the surface is $0.002 \mathrm{ft} / \mathrm{d}$, which is similar to the smallest measured seepage rates. Streambed conditions, however, are diverse throughout the study area. The actual seepage rate at any particular location likely differs from values averaged across entire model cells that the simulated discharge rate represents. Seepage rates in wetlands and tributaries likely differ from those measured in the James River. In addition, because of limited access to the river, seepage measurements were made close to the river shore. Seepage rates generally decline exponentially with distance from shore. Thus, the seepage measurements possibly have a high bias and are not representative of seepage rates across the entire width of the streambed.

Approximately 17 percent of the water in the lower model layer that does not return to the upper layer is intercepted and removed by well withdrawal, and the rest flows across the constant-head boundary to recharge regional aquifers ( $\left.\operatorname{tab}^{1} \mathrm{e}, 4\right)$. Parts of the model area in which regional recharge originates possibly are distinct. Examination of model cell-by-cell flow data indicate that downward leakage into the lower layer primarily takes place in parts of the layer corresponding to the uplands. Areas in which recharge at the water table contributes to regional recharge were delineated by using particle-tracking analysis of model data. Particle endpoint locations were calculated by using MODPATH (Pollock, 1989). Particle starting locations were specified within the constant-head boundary cells along the northeastern and eastern sides of the lower layer. A backward tracking 
Table 4. Simulated rates of ground-water-flow components in the Fall Zone near Richmond, Virginia

\begin{tabular}{|c|c|c|c|c|}
\hline \multirow[b]{2}{*}{$\begin{array}{l}\text { Ground-water-flow } \\
\text { component }\end{array}$} & \multicolumn{2}{|c|}{ Simulated withdrawals included } & \multicolumn{2}{|c|}{ Simulated withdrawals not included } \\
\hline & $\begin{array}{l}\text { SImulated flow rate } \\
\text { (Inches per year) }\end{array}$ & Percent of total & $\begin{array}{l}\text { Simulated flow rate } \\
\text { (Inches per year) }\end{array}$ & Percent of total \\
\hline Recharge & 10.0 & 100 & 10.0 & 100 \\
\hline Downward leakage & 1.1 & 11 & 1.1 & 11 \\
\hline Upward leakage & .5 & 5 & .6 & 6 \\
\hline $\begin{array}{l}\text { Discharge to rivers, wetlands, and } \\
\text { tributaries }\end{array}$ & 9.4 & 94 & 9.5 & 95 \\
\hline Withdrawal from reported supply wells & .1 & 1 & .0 & 0 \\
\hline Flow into regional flow system & .5 & 5 & .5 & 5 \\
\hline
\end{tabular}

procedure was then used to track the particles in reverse along flow paths to their points of origin at the water table in the upper unconfined aquifer layer. The resulting locations were delineated to identify regional recharge areas (fig. 11). Recharge at the water table within these areas is inferred to leave the model area by flowing into the regional flow system. Conversely, recharge at the water table elsewhere within the model area is discharged to the surface within the model area or, to a smaller degree, removed by withdrawal.

Most of the regional recharge originates in the northeastern upland (fig. 11). Only in a small part of the southeastern upland does recharge at the water table contribute to regional recharge, and no watertable recharge in the western upland contributes to regional recharge. Apparently, much of the water that leaks downward beneath the southeastern and western uplands subsequently flows back upward or is removed by withdrawal.

In order to evaluate possible effects of the simulated withdrawal, a separate simulation was performed with the well withdrawals set to zero. All other model specifications were unaltered. This second simulation cannot be interpreted as representing regional prewithdrawal conditions, however, because the constanthead boundary on the northeastern and eastern sides of the lower layer is based on a regional hydraulic gradient that is affected by withdrawals outside of the model area.

Simulated flow rates were recalculated to provide estimates of the relative magnitudes of different components of flow through the study area in the absence of the simulated withdrawal (table 4). The flow rates are nearly equal to the flow rates calculated in the first simulation. The amounts of water that enter the model area as recharge in the upper layer, leak downward into the lower layer, and flow across the constant-head boundary to recharge region $\rightarrow 1$ aquifers are virtually the same as in the first simulation. The small amount of water that is not removed by withdrawal is added to the water that flows bac's upward into the upper layer and discharges to the surface. Thus, a possible effect of the withdrawal is to reduce discharge to the surface by approximately $0.1 \mathrm{in} / \mathrm{yr}$ or 1 percent. The small difference between the simulations, however, is probably insignificant given the limitations of the model.

\section{RELATIONS BETWEEN LOCAL AND REGIONAL FLOW SYSTEMS}

Ground-water-flow system conditiors within the study area are consistent with documerted conditions in other parts of the Virginia Coastal Plain. Areas of recharge and discharge within the study area generally coincide with regional recharge and discharge areas. Flow system conditions within the s'udy area likely differ, however, with potential conditions in other parts of the Virginia Fall Zone. Spatial distributions of aquifers, spatial relations among surface and subsurface flow systems, and possibly amcunts of recharge to regional aquifers, are different in different parts of the Fall Zone.

\section{Virginia Coastal Plain}

The Fall Zone historically has been viewed as a major upgradient regional recharge area fo" the Coastal Plain aquifers. Previous studies within the Coastal Plain in Virginia (Harsh and Laczriak, 1990; Hamilton and Larson, 1988; Laczniak and Meng, 
I988) consistently indicate that the principal areas of downward leakage into the confined aquifers lie along the Fall Zone and along major surface-drainage divides. Conversely, upward leakage and groundwater discharge occurs primarily beneath major rivers and along coastal areas. The incision of the rivers and associated fluvial sediments into the aquifers and confining units enhances the hydraulic connections that promote ground-water discharge at the land surface.

Hydrogeologic conditions in the Fall Zone are diverse and complex and have been only generally described by previous studies. The vertical sequence of aquifers beneath the Fall Zone differs from that in other parts of the Coastal Plain because of different erosional and depositional histories (fig. 3). In the Fall Zone, shallow, unconfined aquifers crop out and are bounded by bedrock in the Piedmont to the west. The distributions of outcrop areas and flow boundaries are varied along the Fall Zone. Flow interactions between aquifers and streams result because of direct hydraulic connections at the land surface. Geomorphological features differ among the streams that cross the Fall Zone and affect the hydraulic connections between the streams and underlying aquifers. In addition, hydrologic processes in the Fall Zone function on a more local scale than in other parts of the Coastal Plain. Recharge and discharge locations are in proximity, and ground-water flowpaths and traveltimes are short. Withdrawal within the Fall Zone from shallow, surface-connected aquifers possibly causes water-level declines and induces stream infiltration that are more focused and problematic than elsewhere in the Coastal Plain. By contrast, previous studies have characterized the shallow unconfined aquifer as a constant-head source, which does not account for flow interactions between aquifers and streams.

Although previous descriptions of the Fall Zone are generalized, they are consistent with hydrogeologic conditions within the study. Areas of regional recharge coincide with the major surface-drainage divides in the uplands. Because the rivers within the study area are deeply incised, however, almost half of the water that leaks downward subsequently leaks back upward to discharge at the surface, and does not contribute to regional recharge. Withdrawal within the study area possibly reduces surface discharge by a small amount.

Large, regional-scale cones of depression associated with water-level declines at major withdrawal centers, primarily located in the southeastern part of the Coastal Plain in Virginia, have redirected the flow in some aquifers during the past several decades toward the withdrawal centers (Hạrsh and Laczniak, 1990; Hamilton and Larson, 1988; Laczniak and Meng, 1988). In addition, the withdrawals have induced an increase in the amoun ${ }^{4}$ of downward leakage and have intercepted some of the ground water that would otherwise discharge at the land surface. Regionally, the amount of downward leakage and confined aquifer recharge is estimated to have increased from $3.2 \mathrm{in} / \mathrm{yr}$ in 1890 prior to the withdrawals to $3.8 \mathrm{in} / \mathrm{yr}$ in 1980 (Harsh and Laczniak, 1990). During the same period, discharge at the land surface decreased from 2.8 to $2.2 \mathrm{in} / \mathrm{yr}$.

Regional-scale effects of $w^{i}$ thdrawal on the middle Potomac aquifer are documented within the study area. The middle Potomac aquifer is the principal confined aquifer within the strdy area, and it also is the single most important sourc s of ground water in the Virginia Coastal Plain, supplying more than half of the water withdrawn (Harsh and Laczniak, 1990). During development of the regional RASA model (Harsh and Laczniak, 1990), areas were delineated across the entire Virginia Coastal Plain to distinguish between downward leakage into the middle Potomac aquifer and upward leakage from the aquifer into overlying aquifers or as discharge at the land surface. Prior to the large regional withdrawals, the area of upward leakage extended across a large pert of the Virginia Coastal Plain, including most of the study area in this report. Areas of downward leakag? were positioned primarily along major surface-dra'nage divides and a narrow belt next to the Fall Line. As of 1980, the area of downward leakage had expanded to include most of the Virginia Coastal Plain, and areas of upward leakage had shrunk to a few isolated remnants, one of which occupies part of the study area, in this report, along the James and Appomattox Rivers. In addition, as indicated by a separate ground-water-flow model constructed to represent the York-James Peninsula (Laczniak and Meng, 1988), areas of depleted groundwater discharge at the land surface that resulted from withdrawals as of I 983 were delineated along several major rivers, including most of the James and Appomattox Rivers within the study area in this report. 


\section{Virginia Fall Zone}

Hydrogeologic conditions in other parts of the Fall Zone likely differ from those in the study area and, consequently, relations to the regional flow system also could differ. First, diverse hydrogeologic conditions in different parts of the Fall Zone could result from different spatial distributions of the aquifers. The distributions of aquifer outcrop areas, as well as structural features such as faults, vary along the Fall Zone (Mixon and others, 1989). The part of the Fall Zone that includes Richmond (and the study area in this report) and extends south to the Virginia-North Carolina border is the major outcrop area for the gravel member of the Bacons Castle Formation, which consists of the upper part of the unconfined YorktownEastover aquifer. Confined aquifers in this part of the Fall Zone include not only the middle Potomac aquifer but also the upper Potomac-Brightseat aquifer. Beginning north of Richmond (outside of the study area), and extending along the Fall Zone as far as the Potomac River (fig. 1), the Chesapeake Group sediments crop out that include the lower part of the unconfined Yorktown-Eastover aquifer and the underlying Calvert confining unit. Confined aquifers in this part of the Fall Zone include not only the middle Potomac aquifer but also the lower Potomac, Aquia, and Chickahominy-Piney Point aquifers. This area also includes buried faults and sedimentary rock. The northernmost part of the Fall Zone in Virginia is the principal outcrop area of the middle Potomac aquifer, and it also includes a large and complex fault system.

Second, diverse hydrogeologic conditions in different parts of the Fall Zone could result from different spatial relations among surface and subsurface flow systems. Geomorphological features, such as stream channels, floodplains, and terraces differ among the streams that cross the Fall Zone and affect the hydraulic connections between the streams and underlying aquifers. The James River is the largest surface-water drainage system to cross the Fall Zone entirely within Virginia, and it was the principal focus of the study area in this report. The channel of the James River is broad and deep, and its adjoining terraces, floodplains, and wetlands that represent the unconfined Columbia aquifer are extensively developed. Several other drainage systems also cross the Fall Zone in Virginia. Drainage systems to the south of the study area also have large terraces, floodplains, and wetlands, but occupy small shallow channels. Drainage systems to the north of the study area have narrower terraces and floodplains and also occupy small channels. The northernmost part of the Fall Zone in Virginia is bounded to the east by the Potomac River (fig. 1), which is the largest drainage system, and which imposes a major hydrologic boundary along the entire north side of the Coastal Plain aquifers in Virginia, which extends from the Fall Zone eastward to Chesapeake Bay.

Because of the large size of the James River and extent of its adjoining floodplains, wetlands, and terraces, the potential discharge of ground water to the James River within the study area probably is greater than along the smaller drainage systems that cross the Fall Zone elsewhere in Virginia. Incision of the river channel and associated fluvial sediments irto the middle Potomac aquifer, and outcrops of the aquifer at steep bluffs along parts of the river, promo ${ }^{+}$the local discharge of water that possibly would otherwise recharge regional aquifers. The regional hydraulic gradient (Hammond and others, 1994) indicates that much of the regional recharge from near the James River probably is intercepted by the nearest large withdrawal center at West Point (fig. 1).

Detailed information on the relations between surface and subsurface flow system in the smaller drainage systems that cross the Fall Zone in Virginia does not exist. Incision of channels and (or) fluvial sediments in smaller systems likely is less than along the James River. Outcrops of the middle Potomac aquifer are small or absent (Mixon and oth Therefore, potentially less ground water is discharged locally to the smaller drainage systems, and regional recharge could be greater. Any significantly large withdrawals, within and near these drainago systems, however, could potentially reduce surface discharge and (or) regional recharge. The regional hydraulic gradient (Hammond and others, 1994) indicates that much of the regional recharge from near the small drainage systems north of Richmond is intercepted probably by the nearest large withdrawal center at West Point (fig. 1). Much of the regional recharge from near the small drainage systems soutl of Richmond is intercepted probably by the nearest large withdrawal center at Franklin (fig. 1).

Detailed information on the relations between surface and subsurface flow systems in the northernmost part of the Fall Zone in Virginia does not exist. Because of the eastward position and very large size of the Potomac River, and extensive outcrops of the middle Potomac aquifer, much of the ground water is 
discharged probably to the river and its local tributaries. Any ground water that continues into the regional system flows southeastward in the downgradient direction into southern Maryland. Large and increasing withdrawals in southern Maryland have resulted from accelerated residential and commercial development (Fleck and Vroblesky, 1996), and they likely intercept some part of the regional recharge originating from the northernmost part of the Fall Zone in Virginia. In addition, significant regional-scale groundwater-flow interactions probably exist between withdrawals in both Maryland and Virginia along much of the length of the Potomac River, from the Fall Zone eastward to Chesapeake Bay. Although RASA studies in both Virginia (Meng and Harsh, 1988; Harsh and Laczniak, 1990) and Maryland (Fleck and Vroblesky, 1996) have included the Potomac River as a regionalscale hydrologic boundary, more detailed local-scale studies comparable to that in this report have not been conducted.

\section{SUMMARY AND CONCLUSIONS}

The western margin of the Coastal Plain Physiographic Province, termed the Fall Zone, near Richmond, Virginia, was delineated into (1) a lowland next to the James and the Appomattox Rivers having Quaternary-age sediments at the land surface that represent the unconfined Columbia aquifer, and (2) three adjoining uplands having Tertiary-age sediments at the land surface that represent the unconfined part of the Yorktown-Eastover aquifer. The unconfined aquifers are bounded to the west by Petersburg granite in the Piedmont. The surficial sediments throughout the study area represent terrace, floodplain, and channelfill deposits, and they consist largely of sand and gravel that contain varying amounts of silt and clay. Estimated horizontal hydraulic conductivities of the lowland Columbia aquifer ranged from 5.6 to $76 \mathrm{ft} / \mathrm{d}$, which are greater than those of the upland YorktownEastover aquifer that ranged from 0.0084 to $1.3 \mathrm{ft} / \mathrm{d}$.

In the study area, the unconfined aquifers are underlain primarily by Cretaceous-age fluvial sediments of the Potomac Formation that represent the confined middle Potomac aquifer, and by one or more intervening confining units. The middle Potomac aquifer consists of sand and gravel interbedded with discontinuous lenses of silt and clay. Estimated horizontal hydraulic conductivities ranged from 0.22 to $6.1 \mathrm{ft} / \mathrm{d}$. The confining units consist of fine sand, silt, and clay marine deposits of the Saint Marys, Nanjemoy, and Aquia Formations of Tertiary age. A confining unit and Piedmont bedrock underlie the middle Potomac aquifer. The middle Potomac aqvifer, confining units, and underlying bedrock dip regionally eastward. The middle Potomac aquifer and confining units are incised by varying degrees in dif ${ }^{c}$ erent parts of the lowland by the James River and the Columbia aquifer.

Analysis of hydraulic grad:ents and the spatial relations among the aquifers, corfining units, James and Appomattox Rivers, adjoinirg wetlands, and tributary streams, indicated that much of the water that enters the unconfined aquifers as recharge at the water table probably flows a short distance before discharging to tributary streams, and less water is discharged directly to the James and Appom?ttox Rivers and adjoining wetlands. An additional unknown amount of water is removed by withdrawal from water-supply wells and partly returned by septis systems. Part of the unconfined water also leaks downward, primarily beneath the uplands, through the underlying confining units to recharge the confined middle Potomac aquifer. Ground water in the middle Potomac aquifer either (1) leaks back upward to discharge within the study area into the James and Appomattox Pivers and adjoining wetlands, (2) is removed from the aquifer by withdrawal from water-supply wells located within the study area, or (3) flows through the aquifer and out of the study area in downgradient directions to the northeast and east to recharge regional aquifers.

Recharge at the water table occurs primarily during the cooler half of the year, when rates of evapotranspiration are small. Water-level changes and leakage into the confined middle Potomac aquifer occurs in response to recharge at the water table. Short-term water-level fluctuations in the lowland result from individual recharge events, and from tidal fluctuations of the James River.

Ground-water flow in the study area was simulated with a finite-difference numerical model consisting of two layers - an upper layer that represents the unconfined Columbia and Yorktown-Eastover aquifers, and a lower layer that represents the confined middle Potomac aquifer. External and internal boundaries on the model layers were specified to correspond to the spatial configurations of the aquifers, confining units, James and Appomattox Rivers, adjoining wetlands, and tributaries. Water that enters the model area was simulated as recharge at the water table in the upper unconfined aquifer layer. W/ater flows laterally 
through the upper layer and downward into the lower confined aquifer layer. Water also flows upward from the lower layer into the upper layer. Water leaves the model area by either (1) discharging from the upper layer to head-dependent flow cells (representing the rivers, wetlands, and tributaries), (2) discharging from the lower layer across a constant-head boundary (representing recharge to regional aquifers), or (3) discharging from the lower layer to well cells (representing withdrawals from water-supply wells).

Simulated directions of flow generally are consistent with those inferred from field data. Particletracking analysis of model data, in conjunction with chlorofluorocarbon-analysis of ground-water samples, indicate ground-water ages and traveltimes that range from near 0 years at the water table to approximately 50 years at the base of the unconfined aquifers and near the top of the confined middle Potomac aquifer. Particle-tracking analyses also delineated areas in which recharge at the water table enters the regional flow system.

Simulated flow rates indicate that approximately half of the water that leaks downward into the middle Potomac aquifer within the study area flows back upward to discharge at the surface. Of the remaining amount, approximately 17 percent is removed by withdrawal and the rest provides recharge to regional aquifers.

Hydrogeologic conditions within the study area are consistent with previously documented regionalscale conditions across the Virginia Coastal Plain. Hydrogeologic conditions within the study area likely differ, however, from other parts of the Fall Zone, which have different spatial distributions of aquifers, and different spatial relations among surface and subsurface flow systems. The amounts of ground water that contribute to local discharge and regional recharge, as well as the degree to which withdrawals decrease local discharge and regional recharge, could vary among other parts of the Fall Zone. Detailed information on the relations between surface and subsurface flow systems is needed on other parts of the Fall Zone before relations of the Fall Zone to the regional flow system can be fully known.

\section{REFERENCES CITED}

Bouwer, Herman, and Rice, R.C., 1976, A slug test for determining hydraulic conductivity of unconfined aquifers with completely or partially pene'rating wells: Water Resources Research, v. 12, no. 3, p. 423-428.

Bradbury, K.R., and Muldoon, M.A., 1990, Hydraulic conductivity determinations in unlithified gla:ial and fluvial materials: Ground Water and Vadose Zone Monitoring, American Society for Testing and Materials Standard Technical Publication 1053, p. 138-151.

Busenberg, Eurybiades, and Plummer, L.N., 1992, Use of chlorofluorocarbons $\left(\mathrm{CCl}_{3} \mathrm{~F}\right.$ and $\left.\mathrm{CCl}_{2} \mathrm{~F}_{2}\right)$ as hydrologic tracers and age-dating tools--The alluviurn and terrace system of central Oklahoma: Water Resolrces Research, v. 28 , no. 9, p. 2257-2283.

Cederstrom, D.J., 1945, Geology and ground-v/ater resources of the Coastal Plain in southeastern Virginia: Virginia Geological Survey, Bulletin 63, 384 p.

Clark, W.B., and Miller, R.L., 1912, The physiography and geology of the Coastal Plain province of Virginia: Virginia Geological Survey, Bulletin 4, p. 13-322.

Cooley, R.L., and Naff, R.L., 1990, Regression modeling of ground-water flow: U.S. Geological Survey Techniques of Water-Resources Investigations. book 3, chap. B4, $232 \mathrm{p}$.

Dischinger, J.B., 1987, Late Mesozoic and Cerozoic stratigraphic framework near Hopewell, Virginia: U.S. Geological Survey Bulletin 1567,71 p.

Fleck, W.B., and Vroblesky, D.A., 1996, Simulation of the ground-water flow system of the Coastal Plain sediments: Maryland, Delaware, and the District of Columbia: U.S. Geological Professional F^per 1404-J.

Franke, O.L., Reilly, T.E., and Bennett, G.D., 1987, Definition of boundary and initial conditions in the analysis of saturated ground-water flow systems--An introduction: U.S. Geological Survey Techniques of WaterResources Investigations, book 3, chap. B5, 15 p.

Freeze, R.A., and Cherry, J.A., 1979, Groundwater: Englewood Cliffs, N.J., Prentice-Hall, p. 136-137.

Hamilton, P.A., and Larson, J.D., 1988, Hydrogeology and analysis of the ground-water flow system in the Coastal Plain of southeastern Virginia: U.S. Geological Survey Water-Resources Investigations Report 874240, $175 \mathrm{p}$.

Hammond, E.C., McFarland, E.R., and Focazio, M.J., 1994, Potentiometric surface of the middle Potonac aquifer in Virginia, 1993: U.S. Geological Survey Open-File Report 94-372, $1 \mathrm{p}$.

Harned, D.A., 1989, The hydrogeologic framework and a reconnaissance of ground-water quality in the Piedmont Province of North Carolina, with a design for future study: U.S. Geological Survey Water-Resources Investigations Report 88-4130, $55 \mathrm{p}$.

Harsh, J.F., and Laczniak, R.J., 1990, Conceptualization and analysis of ground-water flow system in the Coastal Plain of Virginia and adjacent parts of Maryland and North Carolina: U.S. Geological Professicnal Paper 1404-F, 100 p. 
Heath, R.C., 1984, Ground-water regions of the United States: U.S. Geological Survey Water-Supply Paper 2242,78 p.

Johnson, G.H., and Ramsey, K.W., 1987, Geology and geomorphology of the York-James peninsula, Virginia: Atlantic Coastal Plain Geological Association 1987 Meeting, College of William and Mary, Williamsburg, Virginia, $45 \mathrm{p}$.

Johnston, R.H., 1976, Relation of ground water to surface water in four small basins of the Delaware Coastal Plain: Delaware Geological Survey Report of Investigations No. 24, 56 p.

Laczniak, R.J., and Meng. A.A., III, 1988, Ground-water resources of the York-James peninsula of Virginia: U.S. Geological Survey Water-Resources Investigations Report 88-4059, 178 p.

Lee, D.R., 1977, A device for measuring seepage flux in lakes and estuaries: Limnology and Oceanography, v. 22 , p. $140-147$.

McDonald, M.G., and Harbaugh, A.W., 1988, A modular three-dimensional finite-difference ground-water flow model: U.S. Geological Survey Techniques of WaterResources Investigations, book 6, chap. A1, $576 \mathrm{p}$.

McFarland, E.R., 1995, Ground-water flow, geochemistry, and effects of agricultural practices on nitrogen transport at study sites in the Piedmont and Coastal Plain physiographic provinces, Patuxent River Basin, Maryland

McFarland, E.R., and Focazio, M.J., 1993, Ground water in Virginia: use during 1990, availability, and resource information needs: U.S. Geological Survey Open-File Report 94-114, 2 p.

Meng, A.A., III, and Harsh, J.F., 1988, Hydrogeologic framework of the Virginia Coastal Plain: U.S. Geological Survey Professional Paper 1404-C, 81 p.

Mixon, R.B., Berquist, C.B., Jr., Newell, W.L., and Johnson, G.H., 1989, Geologic map and generalized cross sections of the Coastal Plain and adjacent parts of the Piedmont, Virginia: U.S. Geological Survey Miscellaneous Investigations Series Map 1-2033.
National Weather Service, 1996, Climatological data, Virginia, December 1996, v. 106, no. 12, 26 p.

Onuschak, E., Jr., 1972, February 1972 deep test in Accomack County, Virginia: Virginia Division of Mineral Resources, Virginia Minerals, v. 18, no. 1, p. 1-4.

Pollock, D.W., 1989, Documentation of computer programs to compute and display pathlines using results from the U.S. Geological Survey modular three-dimensional finite-difference ground-water flow model: U.S. Geological Survey Open-File Repo+t 89-381, 188 p.

Rasmussen, W.C., and Andreasen, G.E., 1959. Hydrologic budget of the Beaver Dam Creek Basin, Maryland: U.S. Geological Survey Water-Supply Paper 1472. $106 \mathrm{p}$.

Richardson, C.A., 1980, Ground water in the Piedmont upland of central Maryland: U.S. Geological Survey Water-Resources Investigations Report 80-18, $42 \mathrm{p}$.

Richardson, D.L., 1994, Ground-water discharge from the Coastal Plain of Virginia: U.S. Geological Survey Water-Resources Investigations Report 93-4191, 15 p.

Sanford, Samuel, 1913, The underground water resources of the Coastal Plain province of Virginia: Virginia Geological Survey, Bulletin 5, $361 \mathrm{p}$.

Seaber, P.R., Kapinos, F.P., and Knapp, G.L., 1987, Hydrologic unit maps: U.S. Geological Survey Water-Supply Paper 2294, 63 p.

van der Kamp, Garth, 1976, Determining aquifer transmissivity by means of well response tests: the underdamped case: Water Resources Research, v. 2, no. 1, p. $71-77$.

Ward, L.W., 1985, Stratigraphy and characteristic mollusks of the Pamunkey Group (lower Tertiary) and the Old Church Formation of the Chesapeake Group--Virginia Coastal Plain: U.S. Geological Survey Professional Paper 1346.

Ward, L.W., and Blackwelder, B.W., 1980, Stratigraphic revision of the upper Miocene and lower Pliocene beds of the Chesapeake Group, midd'c Atlantic Coastal Plain: U.S. Geological Survey Rulletin 1482-D, 71 p. 


\section{Appendix 1.-Characteristics and geologic logs of observation wells in the Fall Zone near Richmond, Virginia}




\section{DEPTH (feet)}

GEOLOGIC LOG

\section{FORMATION: Yorktown}

2-30 fine- to medium-grained quartz sand, few pebbles, orange (10 YR 6/6), wet near base with red mottling (10 YR 8/2) and heavy minerals

31-34 medium-grained sand, wet, dark pink (5 R 5/4)

35-41 as from 2-30 depth above

$42 \quad$ gravel

43-48 silty clay, orange (5 YR 5/6), some brown ironstone

49-60 fine- to medium-grained sand, orange, gray and dry near top, some ironstone

61-92 fine sand, orange mixed with buff ( 5 Y 8/4), very fine with silt and heavy minerals in lo'ver part

93-100 silt, dense, dark gray ( 5 GY 4/1)

FORMATION: Virginia Saint Marys

FORMATION: Aquia

101-117 silty fine- to medium-grained sand, dark blue (N 3), some pebbles increasing toward base, abrupt refusal

WELL: $52 \mathrm{G} 22$

DEPTH BELOW LAND SURFACE: 16.77 feet

AQUIFER: YORKTOWN-EASTOVER

WELL: $52 G 23$

DEPTH BELOW LAND SURFACE: 27.09 feet

AQUIFER: MIDDLE POTOMAC

WELL: 52G 24

DEPTH BELOW LAND SURFACE: 64.79 feet

AQUIFER: MIDDLE POTOMAC
LATITUDE: $37^{\circ} 20^{\prime} 31^{\prime \prime}$

LONGITUDE: $77^{\circ} 20^{\circ} 00^{\prime \prime}$

LAND-SURFACE ELEVATION: 70 feet

LATITUDE: $37^{\circ} 20^{\prime} 31^{\prime \prime}$

LONGITUDE: $77^{\circ} 20^{\prime} 00^{\prime \prime}$

LAND-SURFACE ELEVATION: 70 feet

LATITUDE: $37^{\circ} 20^{\prime} 31^{\prime \prime}$

LONGITUDE: $77^{\circ} 20^{\prime} 00^{\prime \prime}$

LAND-SURFACE ELEVATION: 70 feet

\begin{tabular}{l}
\hline DEPTH (feet) \\
GEOLOGIC LOG
\end{tabular}

3-5 clayey coarse-grained quartz sand, orange (10 YR 6/6)

18 as $3-5$ depth above

FORMATION: Yorktown

$18-20$

FORMATION: Aquia

clayey silt and fine-grained sand, dark blue ( 5 GY 2/1), micaceous, glauconitic

$28-30$

$68-70$

FORMATION: Potomac

coarse-grained quartz sand, pebbly, clayey, gray $(5$ Y 6/1)

$73-75$ sandy clay, very tough and dense, dark gray ( $5 \mathrm{GY} 4 / 1$ ), coarse sand grains, pebbly toward top, fractures in clay with light gray linings coarse- to very coarse-grained sand and gravel, clayey, vericolored (top 5 YR 6/4, bottom N 9) 


$\begin{array}{ll}\begin{array}{l}0-5 \\ 6-16\end{array} & \begin{array}{l}\text { silty sand } \\ \text { fine-grained quartz sand, some hea }\end{array} \\ 17-27 & \text { silt, sandy, clayey, very micaceous, } \\ & \\ 28-47 & \text { sand, milley matrix, some gamets } \\ 48-56 & \text { clay, green gray } \\ 57 & \text { sand } \\ 58-59 & \text { clay } \\ 60-72 & \text { sand }\end{array}$

FORMATION: alluvium

FORMATION: Aquia

FORMATION: Potomac

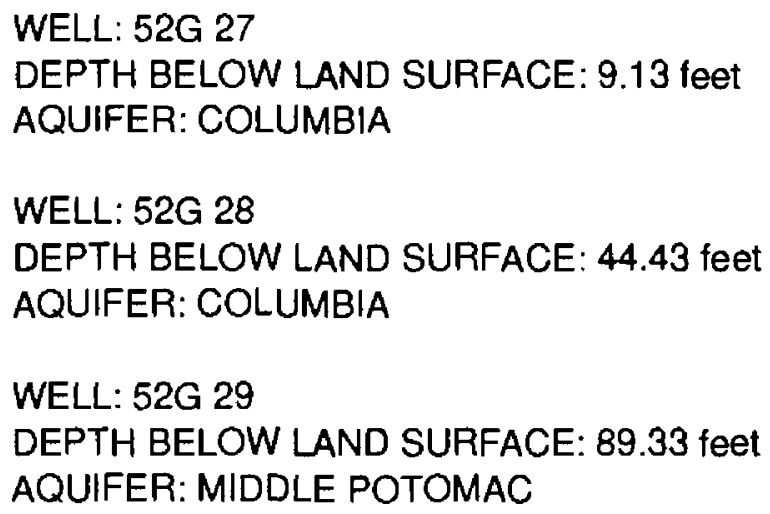

LATITUDE: $37^{\circ} 22^{\prime} 02^{\prime \prime}$

LONGITUDE: $77^{\circ} 16^{\prime} 02^{\prime \prime}$

LAND-SURFACE ELEVATION': 4.04 feet

LATITUDE: $37^{\circ} 22^{\prime} 02^{\prime \prime}$

LONGITUDE: $77^{\circ} 16^{\prime} 02^{\prime \prime}$

LAND-SURFACE ELEVATION': 3.81 feet

LATITUDE: $37^{\circ} 22^{\prime} 02^{\prime \prime}$

LONGITUDE: $77^{\circ} 16^{\prime} 02^{\prime \prime}$

LAND-SURFACE ELEVATION: 3.97 feet

\section{DEPTH (feet)}

GEOLOGIC LOG

FORMATION: alluvium
$0-2$
soil, brown
$3-4$
medium-grained quartz sand, clayey, dense, brown
$5-9$
$10-19$
$20-45$
46
sand, gray brown, mottled, soupy
gravel and coarse sand, orange, soupy
coarse pebbly sand, soupy
coarse sand, mint green, soupy

\section{FORMATION: Potomac}
coarse sand, pebbly, clayey with clay clasts, indurated, pinkish buff clay, pebbly, pinkish buff sand, pinkish buff medium-grained sand, clayey, off-white pebbly sand, pinkish buff medium-grained sand, silty, stiff, orange mottles, few gray green clay clasts increase toward base 


\section{FORMATION: Bacons Castle}

$4-5.5$

9-10.5

$14-15.5$

$19-20.5$

$24-25.5$

$29-30.5$

34-35.5

$39-39.2$

$39.3-40.5$

$44-45.5$

$49-50.5$

$54-55.5$

$59-60.5$

64-65.5

69-70.5

$74-75.5$

$79-80.5$

$84-85.5$

$89-90.5$

94-95.5

$99-100.5$ clayey silt, reddish orange (5 YR 5/6), some sand

clayey fine-grained sand, orange (10 YR 6/6)

sandy clay, moist, orange (10 YR 6/6)

top 0.5 same as 14-15.5 depth, remainder medium-grained sand, orange (10 YR 6/6), vet, lense of coarse sand, brown (5 YR 3/4)

sandy silt, $\tan (5$ YR 5/6), saturated, poor recovery

FORMATION: Eastover

medium-grained sand, gray ( 5 Y 4/1), well sorted, saturated, some glauconite or heavy minerals

medium-grained sand, slightly clayey, blue gray (N 4), saturated, botryoidal glauconite grains, dipyrimidal heavy mineral grains

as from 34-35.5 depth above

FORMATION: Calvert

silty clay, stiff, dry, green gray ( 5 GY $4 / 1$ )

as from $39.3-40.5$ above

as from $39.3-40.5$ above

as from $39.3-40.5$ above

fine-grained sand, clayey, green gray ( 5 GY 4/1), some gluaconite and shell, poor recovery

fine-grained sand, clayey, dark gray (N 3), abundant gluaconite and shell

as from $64-65.5$ above with very abundant gluaconite and shell, visible bivalve and gastropod fragments fine-grained sand, silty, dark gray ( 5 GY 2/1), light gray clay clasts ( 5 GY 6/1), 1-inch diameter some glauconite and shell, shark tooth, half-inch length

fine-grained sand, silty, dark gray ( 5 GY 2/1), some glauconite and shell as from $79-80.5$ depth above

FORMATION: Nanjemoy

clay, silty, sandy, gray green ( 5 GY $3 / 2$ ), some glauconite, shell, and mica as from $89-90.5$ depth above

as from $89-90.5$ depth above, nanofossil assemblege NP1 1-12 
WELL: $52 \mathrm{H} 12$

DEPTH BELOW LAND SURFACE: 43.40 feet

AQUIFER: COLUMBIA

WELL: $52 \mathrm{H} 13$

DEPTH BELOW LAND SURFACE: 79.46 feet AQUIFER: COLUMBIA
LATITUDE: $37^{\circ} 24^{\prime} 47^{\prime \prime}$

LONGITUDE: $77^{\circ} 15^{\prime 2} 29^{\prime \prime}$

LAND-SURFACE ELEVATION: 37.56 feet

LATITUDE: $37^{\circ} 24^{\prime} 47^{\prime \prime}$

LONGITUDE: $77^{\circ} 15^{\prime 2} 29^{\prime \prime}$

LAND-SURFACE ELEVATION: 37.35 feet

DEPTH (feet) GEOLGIC LOG

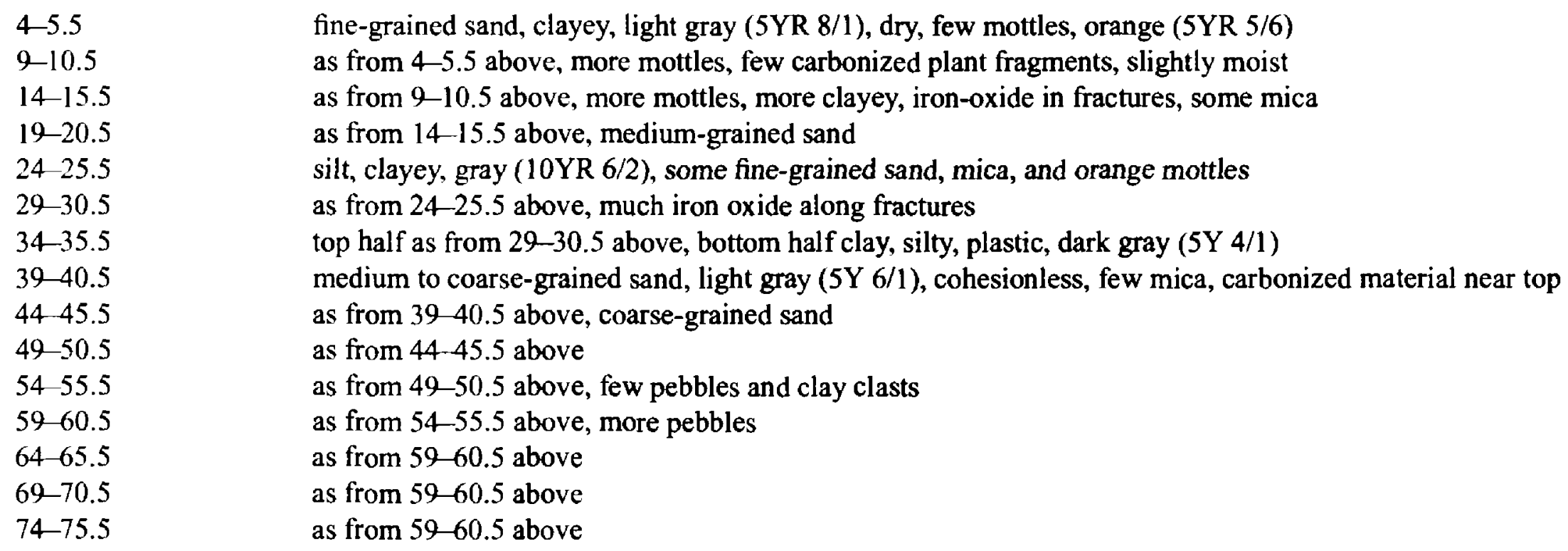

fine-grained sand, clayey, light gray (5YR 8/1), dry, few mottles, orange (5YR 5/6)

as from 4-5.5 above, more mottles, few carbonized plant fragments, slightly moist

as from 9-10.5 above, more mottles, more clayey, iron-oxide in fractures, some mica

as from $14-15.5$ above, medium-grained sand

silt, clayey, gray (10YR 6/2), some fine-grained sand, mica, and orange mottles

as from 24-25.5 above, much iron oxide along fractures

top half as from 29-30.5 above, bottom half clay, silty, plastic, dark gray (5Y 4/1)

medium to coarse-grained sand, light gray ( 5 Y 6/1), cohesionless, few mica, carbonized material near top

as from 39-40.5 above, coarse-grained sand

as from $44-45.5$ above

as from $49-50.5$ above, few pebbles and clay clasts

as from $54-55.5$ above, more pebbles

as from $59-60.5$ above

as from $59-60.5$ above

as from $59-60.5$ above

FORMATION: Chuckatuck

\author{
FORMATION: Aquia
}

top 0.5 pebbles, remainder clay, silty, light gray (5Y 6/1). shell, nanofossil assemblege NP8 


\section{FORMATION: Windsor}

$4-5.5$

9-10.5

14-15.5

1920.5

$24-25.5$

$29-30.5$

$34-35.5$

$39-40.5$

$44-45.5$

$49-50.5$

$54-55.5$

$59-60.5$

$64-65.5$

69-70.5

$74-75.5$

$79-80.5$ clay, silty, orange (10YR 6/6), dry, few gray mottles, fine-grained sand and mica

fine-grained sand, orange (10YR 6/6), dry, low cohesion, few mica and carbonized plant fragments as from $9-10.5$ above, cohesionless

fine-grained sand, orange (10YR 6/6) and gray (5Y 8/1), clayey, some mottles, mica, and carbon staining, dry as from $19-20.5$ above, few half-inch pebbles as from 24-25.5 above, dense lense of inch-diameter gravel, second dense lense of fine-grained sand, orange, iron stained

as from $29-30.5$ above, more gravel, some iron-oxide coatings and stains as from $34-35.5$ above, medium-grained sand, $\tan (10 \mathrm{YR} 7 / 4$ )

gravel and medium-grained sand, wet, iron stained, some clay, heavy, plastic, orange (10YR 6/6)

\section{FORMATION: Potomac}

medium-grained sand, wet, some clay, orange (10YR 6/6) and light gray (10YR 8/2)

medium-grained sand, moist, clayey, light gray (N7), some half-inch pebbles and carbonized plant fragments, few mica

as from $54-55.5$ above, course-grained sand, more pebbles, inch-diameter clay clast, li ght gray (5YR 8/1), clay matrix, gray (N6)

near top medium-grained sand, clayey, tan (10YR 7/4), grades downward to coarse-grained sand and gravel, clayey, gray (N5), moist

medium to coarse-grained sand, clayey, tan (10YR 7/4), some pebbles, moist

medium to coarse-grained sand, light gray (N7), some clay

coarse-grained sand, dark gray (N3), some clay, few pebbles and >inch-long clay clasts, Light gray (N7 and 5 YR 8/1) 
WELL: $52 \mathrm{H} 16$

DEPTH BELOW LAND SURFACE: 33.52 feet

AQUIFER: YORKTOWN-EASTOVER

WELL: $52 \mathrm{H} 17$

DEPTH BELOW LAND SURFACE: 78.56 teet AQUIFER: MIDDLE POTOMAC
LATITUDE: $37^{\circ} 25^{\prime} 38^{\prime \prime}$

LONGITUDE: $77^{\circ} 22^{\prime} 15^{\prime \prime}$

LAND-SURFACE ELEVATION: 135 teet

LATITUDE: $37^{\circ} 25^{\prime} 38^{\prime \prime}$

LONGITUDE: $77^{\circ} 22^{\prime} 15^{\prime \prime}$

LAND-SURFACE ELEVATION: 135 feet
$4-5.5$

$9-10.5$

$14-15.5$

19-20.5

$24-25.5$

$29-30.5$

$34-35.5$

$39-40.5$

$44-45.5$

$49-50.5$

$54-55.5$

$59-60.5$

$64-65.5$

$69-70.5$

$74-75.5$

$79-80.5$
FORMATION: Bacons Castle

clay, silty, pebbly, red (10R 4/6), some fine-grained sand, pebbles up to 1 inch, dry and stiff medium-grained sand, silty, red (IOR 4/6), some pebbles up to half-inch, low cohesion, moist top half as 9-10.5 above, bottom half coarse-grained sand, orange (10YR 6/6), pebbles to 1 inch, friable coarse-grained sand, pebbly, orange (10YR 6/6), moist, friable, low recovery because of spoon refus?l medium to coarse-grained sand, pebbly, orange (10YR 6/6), some clay, friable, very moist as 24-25.5 above, wet, cohesionless

\section{FORMATION: Calvert}

very fine-grained sand, silty, orange (10YR 6/6) and gray (10Y 8/1), mottled, moist as $34-35.5$ above, dark gray (5GY $4 / 1)$

as $39-40.5$ above, plastic

clay, silty, gray green ( 5 GY $6 / \mathrm{I})$, some mica, few glauconite, stiff

\section{FORMATION: Potomac}

coarse-grained sand, pebbly, clayey, dark gray (5GY 4/1), pebbles to half-inch, wet, low cohesion medium-grained sand, light gray (N7), moist, cohesive, micaceous, some carbonized material, clayey medium to coarse-grained sand, light gray (N7), moist, pebbly, pebbles to half-inch, some clay and mica as 64-65.5 above, wet, cohesionless, less clay, no mica as 69-70.5 above, slightly more clayey and cohesive as 74-75.5 above, coarse-grained sand, cohesionless 
Appendix 2.-Characteristics and hydrogeologic log interpretations of water-supply wells in the Fall Zone near Richmond, Virginia 


\title{
ELEVATION (feet above mean sea level) HYDROGEOLOGIC LOG INTERPRETATION
}

$\begin{array}{lc}71-125 & \text { Yorktown-Eastover aquifer } \\ 52-71 & \text { Calvert confining unit } \\ 34-52 & \text { Nanjemoy-Marlboro Clay confining unit } \\ 3-34 & \text { middle Potomac confining unit } \\ -135-3 & \text { middle Potomac aquifer } \\ -151--135 & \text { lower Potomac confining unit } \\ <-151 & \text { Petersburg granite }\end{array}$

$\begin{array}{lc}121-171 & \text { Yorktown-Eastover aquifer } \\ 81-121 & \text { middle Potomac confining unit } \\ 61-81 & \text { middle Potomac aquifer } \\ <61 & \text { Petersburg granite }\end{array}$

$$
\begin{aligned}
& 110-140 \\
& 85-110 \\
& 70-85 \\
& 40-70 \\
& 18-40 \\
& -26-18 \\
& -76--26 \\
& <-76
\end{aligned}
$$

\author{
Yorktown-Eastover aquifer \\ Calvert confining unit \\ Nanjemoy-Marlboro Clay confining unit \\ Aquia aquifer \\ middle Potomac confining unit \\ middle Potomac aquifer \\ lower Potomac confining unit \\ bedrock
}




\section{ELEVATION (feet above mean sea level) HYDROGEOLOGIC LOG INTERPRETATION}

$45-85$

$31-45$

$19-31$

$-5-19$

$-40--5$

$<-40$
Yorktown-Eastover aquifer

Nanjemoy-Marlboro Clay confining unit

Aquia aquifer

middle Potomac confining unit

middle Potomac aquifer

Petersburg granite
WELL NUMBER: $51 \mathrm{H} 191$

AQUIFER: MIDDLE POTOMAC

STATIC WATER-LEVEL ELEVATION (feet above mean sea level): 43
LATITUDE: $37^{\circ} 24^{\prime} 14^{\prime \prime}$

LONGITUDE: $77^{\circ} 25^{\prime} 27^{\prime \prime}$

YEAR OF WATER-LEVEL MEASUFEMENT: 1962

\section{ELEVATION (feet above mean sea level)}

$68-105$

$25-68$

$-11-25$

$-25--11$

$-63--25$

$<-63$

\section{HYDROGEOLOGIC LOG INTERPRETATION}

Columbia aquifer

Nanjemoy-Marlboro Clay confining unit

Aquia aquifer

middle Potomac confining unit

middle Potomac aquifer

Petersburg granite
WELL NUMBER: $52 F 1$

AQUIFER: MIDDLE POTOMAC

STATIC WATER-LEVEL ELEVATION (feet above mean sea level): 55
LATITUDE: $37^{\circ} 13^{\prime} 15^{\prime \prime}$

LONGITUDE: $77^{\circ} 17^{\prime} 19^{\prime \prime}$

YEAR OF WATER-LEVEL MEASUF EMENT: 1994

\section{ELEVATION (feet above mean sea level)}

$-1-37$

$-13--1$

$<-42--13$

\section{HYDROGEOLOGIC LOG INTERPRETATION}

Aquia aquifer

middle Potomac confining unit middle Potomac aquifer
WELL NUMBER: $52 F 4$

AQUIFER: MIDDLE POTOMAC

STATIC WATER-LEVEL ELEVATION (feet above mean sea level): 55
LATITUDE: $37^{\circ} 13^{\prime} 26^{\prime \prime}$

LONGITUDE: $77^{\circ} 17^{\prime} 06^{\prime \prime}$

YEAR OF WATER-LEVEL MEASUFEMENT: 1964

\section{ELEVATION (feet above mean sea level)}

$75-135$

$65-75$

$55-65$

$35-55$

$25-35$

$<-65-25$

\section{HYDROGEOLOGIC LOG INTERPRETATION}

$$
\begin{gathered}
\text { Yorktown-Eastover aquifer } \\
\text { Calvert confining unit } \\
\text { Chickahominy-Piney Point aquifer } \\
\text { Aquia aquifer } \\
\text { middle Potomac confining unit } \\
\text { middle Potomac aquifer }
\end{gathered}
$$




\section{ELEVATION (feet above mean sea level)}

$112-142$

$62-112$

$52-62$

$22-52$

$-18-22$

$-38--18$

$<-58-38$

\section{HYDROGEOLOGIC LOG INTERPRETATION}

Yorktown-Eastover aquifer

Calvert confining unit

Chickahominy-Piney Point aquifer

Nanjemoy-Marlboro Clay confining unit

Aquia aquifer

middle Potomac confining unit middle Potomac aquifer
WELL NUMBER: $52 F 11$

AQUIFER: MIDDLE POTOMAC

STATIC WATER-LEVEL ELEVATION (feet above mean sea level): 59
LATITUDE: $37^{\circ} 14^{\prime} 59^{\prime \prime}$

LONGITUDE: $77^{\circ} 16^{\prime} 31^{\prime \prime}$

YEAR OF WATER-LEVEL MEASUREMENT: 1978

\section{ELEVATION (feet above mean sea level)}

$89-139$

$59-89$

$49-59$

$19-49$

$-11-19$

$-31-11$

$<-54-31$

\section{HYDROGEOLOGIC LOG INTERPRETATION}

Yorktown-Eastover aquifer

Calvert confining unit

Chickahominy-Piney Point aquifer

Nanjemoy-Marlboro Clay confining unit

Aquia aquifer

middle Potomac confining unit

middle Potomac aquifer

\section{ELEVATION (feet above mean sea level)}

$47-89$

$37-47$

$21-37$

$11-21$

$-13-11$

$-31--13$

$-137--31$

$<-211--137$

\section{HYDROGEOLOGIC LOG INTERPRETATION}

Columbia aquifer

Calvert confining unit

Chickahominy-Piney Point aquifer

Nanjemoy-Marlboro Clay confining unit

Aquia aquifer

middle Potomac confining unit

middle Potomac aquifer

lower Potomac confining unit 
$-5-20$

$-20--5$

$-154--20$

$-194--154$

$<-194$
Columbia aquifer middle Potomac confining unit middle Potomac aquifer lower Potomac confining unit bedrock
WELL NUMBER: $52 \mathrm{G} 16$ AQUIFER: MIDDLE POTOMAC

STATIC WATER-LEVEL ELEVATION (feet above mean sea level): 9
LATITUDE: $37^{\circ} 17^{\prime} 27^{\prime \prime}$

LONGITUDE: $77^{\circ} 16^{\prime} 04^{\prime \prime}$

YEAR OF WATER-LEVEL MEASUPEMENT: 1994

\section{ELEVATION (feet above mean sea level) HYDROGEOLOGIC LOG INTERPRETATION}
$-5-45$
Columbia aquifer
$-25--5$
Aquia aquifer
$<-115--25$
middle Potomac aquifer

WELL NUMBER: 52G 17

AQUIFER: MIDDLE POTOMAC

STATIC WATER-LEVEL ELEVATION (feet above mean sea level): -7
LATITUDE: $37^{\circ} 21^{\prime} 05^{\prime \prime}$

LONGITUDE: $77^{\circ} 24^{\prime} 20^{\prime \prime}$

YEAR OF WATER-LEVEL MEASUFEMENT: 1970

\section{ELEVATION (feet above mean sea level) HYDROGEOLOGIC LOG INTERPRETATION}

$6-18$

$-12-6$

$<-164--12$

$-243--164$

$<-260--243$
Columbia aquifer

Aquia aquifer

middle Potomac aquifer

lower Potomac confining unit bedrock
WELL NUMBER: $52 \mathrm{H} 5$

AQUIFER: MIDDLE POTOMAC

STATIC WATER-LEVEL ELEVATION (feet above mean sea level): 40
LATITUDE: $37^{\circ} 26^{\prime} 38^{\prime \prime}$

LONGITUDE: $77^{\circ} 21^{\prime} 18^{\prime \prime}$

YEAR OF WATER-LEVEL MEASUFEMENT: 1972

$\begin{array}{lc}\text { ELEVATION (feet above mean sea level) } & \text { HYDROGEOLOGIC LOG INTERPRETATION } \\ 106-125 & \text { Yorktown-Eastover aquifer } \\ 89-106 & \text { Calvert confining unit } \\ 62-89 & \text { Nanjemoy-Marlboro Clay confining unit } \\ 32-62 & \text { Aquia aquifer } \\ 22-32 & \text { middle Potomac confining unit } \\ -56-22 & \text { middle Potomac aquifer } \\ <-92--56 & \text { lower Potomac confining unit }\end{array}$




\section{$-19-35$}

$-27--19$

$-39--27$

$-55-.39$

$-69--55$

$-88--69$

$-103--88$

$<-180--103$
Columbia aquifer

Calvert confining unit

Chickahominy-Piney Point aquifer

Nanjemoy-Marlboro Clay confining unit

Aquia aquifer

Brightseat-upper Potomac confining unit middle Potomac confining unit middle Potomac aquifer
WELL NUMBER: $53 G 13$ AQUIFER: MIDDLE POTOMAC

STATIC WATER-LEVEL ELEVATION (feet above mean sea level): -5
LATITUDE: $37^{\circ} 21^{\prime} 05^{\prime \prime}$

LONGITUDE: $77^{\circ} 11^{\prime} 36^{\prime \prime}$

YEAR OF WATER-LEVE:L MEASUREMENT: 1980

\section{ELEVATION (feet obove mean sea level)}

\section{HYDROGEOLOGIC LOG INTERPRETATION}

\section{$5-75$}

$-39-5$

$-57--39$

$-71--57$

$-90-.71$

$-107--90$

$-127--107$

$<-215--127$

\section{Columbia aquifer}

Calvert confining unit Chickahominy-Piney Point aquifer Nanjemoy-Marlboro Clay confining unit Aquia aquifer

Brightseat-upper Potomac confining unit middle Potomac confining unit middle Potomac aquifer 

$-20-17$
$-41--20$
$-63--41$
$-77--63$
$-91--77$
$-117--91$
$-133--117$
$-301--133$
$-323--301$
$<-323$

\author{
Columbia aquifer \\ Calvert confining unit \\ Chickahominy-Piney Point aquifer \\ Nanjemoy-Marlboro Clay confining unit \\ Aquia aquifer \\ Brightseat-upper Potomac confining unit \\ middle Potomac confining unit \\ middle Potomac aquifer \\ lower Potomac confining unit \\ lower Potomac aquifer
}

WELL NUMBER: $53 G 16$

AQUIFERS: LOWER POTOMAC AND MIDDLE POTOMAC

STATIC WATER-LEVEL ELEVATION (feet above mean sea level): - 16
LATITUDE: $37^{\circ} 20^{\prime} 12^{\prime \prime}$

LONGITUDE: $77^{\circ} 11^{\prime 2} 25^{\prime \prime}$

YEAR OF WATER-LEVEL MEASUREMENT: 1985

\section{ELEVATION (feet above mean sea level) HYDROGEOLOGIC LOG INTERPRETATION}
$-90--70$
$-106-.90$
$-122--106$
$-298--122$
$-312--298$
$<-312$

Aquia aquifer

Brightseat-upper Potomac confining unit

middle Potomac confining unit middle Potomac aquifer

lower Potomac confining unit lower Potomac aquifer 
WELL NUMBER: $53 \mathrm{H} 2$

AQUIFER: MIDDLE POTOMAC

STATIC WATER-LEVEL ELEVATION (feet above mean sea level): -37
LATITUDE: $37^{\circ} 26^{\prime} 07^{\prime \prime}$

YEAR OF WATER-LEVE!I. MEASUREMENT: 1994

\section{ELEVATION (feet above mean sea level) HYDROGEOLOGIC LOG INTERPRETATION}

$\begin{array}{lc}70-144 & \text { Yorktown-Eastover aquifer } \\ -19-70 & \text { Calvert confining unit } \\ -30--19 & \text { Nanjemoy-Marlboro Clay confining unit } \\ -78--30 & \text { middle Potomac confining unit } \\ <-88-78 & \text { middle Potomac aquifer }\end{array}$

WELL NUMBER: $53 \mathrm{H} 7$

AQUIFER: MIDDLE POTOMAC

STATIC WATER-LEVEL ELEVATION (feet above mean sea level): 1
LATITUDE: $37^{\circ} 25^{\prime} 18^{\prime \prime}$

LONGITUDE: $77^{\circ} 12^{\prime} 31^{\prime \prime}$

YEAR OF WATER-LEVEL MEASUREMENT: 1972

\section{ELEVATION (feet above mean sea level) HYDROGEOLOGIC LOG INTERPRETATION}

$49-143$

$28-49$

$-35-28$

$-56--35$

$-67--56$

$-98--67$

$<-130--98$
Yorktown-Eastover aquifer

Calvert confining unit

Chickahominy-Piney Point aquifer Nanjemoy-Marlboro Clay confining unit

Aquia aquifer

middle Potomac confining unit middle Potomac aquifer 